\title{
Non-pharmacological interventions for assisting the induction of anaesthesia in children (Review)
}

\author{
Manyande A, Cyna AM, Yip P, Chooi C, Middleton P
}

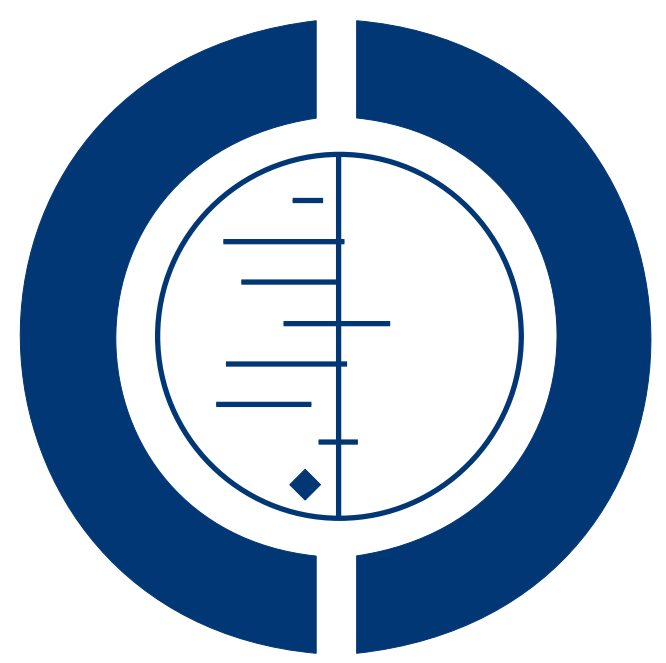

\section{THE COCHRANE COLLABORATION $^{\circledR}$}

This is a reprint of a Cochrane review, prepared and maintained by The Cochrane Collaboration and published in The Cochrane Library 2015, Issue 7

http://www.thecochranelibrary.com

\section{WILEY}

Non-pharmacological interventions for assisting the induction of anaesthesia in children (Review)

Copyright $\odot 2015$ The Cochrane Collaboration. Published by John Wiley \& Sons, Ltd. 
TABLE OF CONTENTS

HEADER . . . . . . . . . . . . . . . . . . . . . . . . . . . . . . . . . . . . . . . . . . . . . . . . .

ABSTRACT . . . . . . . . . . . . . . . . . . . . . . . . . . . . . . . . . . . . . . . . . . . . . . . . . . . .

PLAIN LANGUAGE SUMMARY . . . . . . . . . . . . . . . . . . . . . . . . . . . . . . . . . . . . . . . . . . . . .

SUMMARY OF FINDINGS FOR THE MAIN COMPARISON $\quad . \quad$. . . . . . . . . . . . . . . . . . . . . . . . . . . . . .

BACKGROUND . . . . . . . . . . . . . . . . . . . . . . . . . . . . . . . . . . . . . . . . . . . . . . . . . . . .

OBJECTIVES . . . . . . . . . . . . . . . . . . . . . . . . . . . . . . . . . . . . . . . . . . . . . . . . .

METHODS . . . . . . . . . . . . . . . . . . . . . . . . . . . . . . . . . . . . . . . . . . . . . .

RESULTS . . . . . . . . . . . . . . . . . . . . . . . . . . . . . . . . . . . . . . . . . . . . . . . . . .

ADDITIONAL SUMMARY OF FINDINGS . . . . . . . . . . . . . . . . . . . . . . . . . . . . . . . . .

DISCUSSION . . . . . . . . . . . . . . . . . . . . . . . . . . . . . . . . . . . . . . . . . . 21

AUTHORS' CONCLUSIONS . . . . . . . . . . . . . . . . . . . . . . . . . . . . . . . . . . . . . . .

ACKNOWLEDGEMENTS . . . . . . . . . . . . . . . . . . . . . . . . . . . . . . . . . . . . . . . .

REFERENCES . . . . . . . . . . . . . . . . . . . . . . . . . . . . . . . . . . . . . . 22

CHARACTERISTICS OF STUDIES . . . . . . . . . . . . . . . . . . . . . . . . . . . . . . . . . . . . . . . . . .

DATA AND ANALYSES . . . . . . . . . . . . . . . . . . . . . . . . . . . . . . . . . . . . . . . . . . . . . . . .

Analysis 1.1. Comparison 1 Parental presence versus no parental presence, Outcome 1 anxiety during induction. . . . 67

Analysis 1.3. Comparison 1 Parental presence versus no parental presence, Outcome 3 anxiety during induction (parental anxiety subgroup). . . . . . . . . . . . . . . . . . . . . . . . . . . . . . . . . . . . . . . . . 69

Analysis 1.5. Comparison 1 Parental presence versus no parental presence, Outcome 5 anxiety/distress before induction. 70

Analysis 1.6. Comparison 1 Parental presence versus no parental presence, Outcome 6 parental anxiety (on day of surgery).

Analysis 1.7. Comparison 1 Parental presence versus no parental presence, Outcome 7 parental anxiety (physiological signs).

Analysis 1.8. Comparison 1 Parental presence versus no parental presence, Outcome 8 parental anxiety during induction (parental anxiety subgroup).

Analysis 1.9. Comparison 1 Parental presence versus no parental presence, Outcome 9 parental anxiety postop. . . $\quad 74$

Analysis 1.11. Comparison 1 Parental presence versus no parental presence, Outcome 11 emergence delirium. . . . . 75

Analysis 1.13. Comparison 1 Parental presence versus no parental presence, Outcome 13 time taken for induction (minutes).

Analysis 1.14. Comparison 1 Parental presence versus no parental presence, Outcome 14 negative behaviour postop.

Analysis 1.15. Comparison 1 Parental presence versus no parental presence, Outcome 15 negative behaviour postop.

Analysis 1.16. Comparison 1 Parental presence versus no parental presence, Outcome 16 parental satisfaction. . . .

Analysis 1.17. Comparison 1 Parental presence versus no parental presence, Outcome 17 parental satisfaction. . . .

Analysis 2.2. Comparison 2 Two parents versus one parent, Outcome 2 co-operation during induction. . . . . . .

Analysis 2.3. Comparison 2 Two parents versus one parent, Outcome 3 parental anxiety after leaving OR. . . . .

Analysis 3.1. Comparison 3 Parental presence versus midazolam, Outcome 1 anxiety during induction. . . . . .

Analysis 3.3. Comparison 3 Parental presence versus midazolam, Outcome 3 cooperation during induction. . . .

Analysis 3.5. Comparison 3 Parental presence versus midazolam, Outcome 5 parental anxiety. . . . . . . . . . .

Analysis 3.6. Comparison 3 Parental presence versus midazolam, Outcome 6 time taken for induction (minutes). . .

Analysis 3.7. Comparison 3 Parental presence versus midazolam, Outcome 7 emergence delirium. . . . . . . . . .

Analysis 3.9. Comparison 3 Parental presence versus midazolam, Outcome 9 negative behaviour postop. . . . . . .

Analysis 3.10. Comparison 3 Parental presence versus midazolam, Outcome 10 parental satisfaction. . . . . . .

Analysis 4.1. Comparison 4 Parental presence + midazolam versus no parental presence, Outcome 1 parental anxiety.

Analysis 4.2. Comparison 4 Parental presence + midazolam versus no parental presence, Outcome 2 parental anxiety.

Analysis 5.1. Comparison 5 Video 'fairytale', Outcome 1 co-operation.

Analysis 5.2. Comparison 5 Video 'fairytale', Outcome 2 parental anxiety (STAI $\geq 46$ )

Analysis 5.3. Comparison 5 Video 'fairytale', Outcome 3 parental anxiety (APAIS $>13$ ). . . . . . . . . . . . . . . . . 91

Analysis 5.4. Comparison 5 Video 'fairytale', Outcome 4 parental anxiety (STAI). . . . . . . . . . . . . . . . . . 92

Analysis 5.5. Comparison 5 Video 'fairytale', Outcome 5 parental anxiety (APAIS). . . . . . . . . . . . . . . . . . . . 93

Analysis 6.1. Comparison 6 Low sensory stimulation versus control, Outcome 1 co-operation at induction. . . . . . 94

Analysis 6.2. Comparison 6 Low sensory stimulation versus control, Outcome 2 parental anxiety. $\quad . \quad$. . . . . . . . $\quad$. 94

Non-pharmacological interventions for assisting the induction of anaesthesia in children (Review)

Copyright $\odot 2015$ The Cochrane Collaboration. Published by John Wiley \& Sons, Ltd. 
Analysis 7.1. Comparison 7 Mask introduction/exposure, Outcome 1 anxiety. . . . . . . . . . . . . . . . .

Analysis 7.2. Comparison 7 Mask introduction/exposure, Outcome 2 co-operation (ICC): number of children compliant.

Analysis 7.3. Comparison 7 Mask introduction/exposure, Outcome 3 parental anxiety (STAI: trait). . . . . . . . .

Analysis 11.1. Comparison 11 Video game versus control, Outcome 1 anxiety during induction. . . . . . . . . . .

Analysis 11.2. Comparison 11 Video game versus control, Outcome 2 negative behaviour postop. . . . . . . . . .

Analysis 12.1. Comparison 12 Video game versus midazolam, Outcome 1 anxiety during induction. . . . . . . . .

Analysis 12.2. Comparison 12 Video game versus midazolam, Outcome 2 negative behaviour postop. . . . . . .

Analysis 13.1. Comparison 13 Clowns/clown doctors versus parental presence, Outcome 1 anxiety. . . . . . . .

Analysis 13.2. Comparison 13 Clowns/clown doctors versus parental presence, Outcome 2 co-operation at induction.

Analysis 13.3. Comparison 13 Clowns/clown doctors versus parental presence, Outcome 3 parental anxiety. . . . .

Analysis 13.4. Comparison 13 Clowns/clown doctors versus parental presence, Outcome 4 negative behaviour postop.

Analysis 14.1. Comparison 14 Clowns/clown doctors versus midazolam, Outcome 1 anxiety. . . . . . . . . . . .

Analysis 14.2. Comparison 14 Clowns/clown doctors versus midazolam, Outcome 2 parental anxiety. . . . . .

Analysis 15.1. Comparison 15 Hypnosis versus midazolam, Outcome 1 anxiety during induction. . . . . . . .

Analysis 15.2. Comparison 15 Hypnosis versus midazolam, Outcome 2 negative behaviour postop. . . . . . . .

Analysis 16.1. Comparison 16 Acupuncture for parents, Outcome 1 anxiety during induction. . . . . . . . . . .

Analysis 16.2. Comparison 16 Acupuncture for parents, Outcome 2 co-operation during induction. . . . . . . . .

Analysis 16.3. Comparison 16 Acupuncture for parents, Outcome 3 parental anxiety. . . . . . . . . . . . . . . . .

Analysis 17.1. Comparison 17 Videos for parents, Outcome 1 parental anxiety. . . . . . . . . . . . . . . . . . . . .

APPENDICES . . . . . . . . . . . . . . . . . . . . . . . . . . . . . . . . . . . . .

WHAT'S NEW . . . . . . . . . . . . . . . . . . . . . . . . . . . . . . . . . . . . .

Figure 1. . . . . . . . . . . . . . . . . . . . . . . . . . . . . . . . . . . . . .

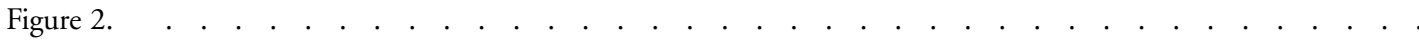

Figure 3. . . . . . . . . . . . . . . . . . . . . . . . . . . . . . . . . . . . .

HISTORY . . . . . . . . . . . . . . . . . . . . . . . . . . . . . . . . . . . . . . .

CONTRIBUTIONS OF AUTHORS . . . . . . . . . . . . . . . . . . . . . . . . . . . . . . . . . . . . .

DECLARATIONS OF INTEREST . . . . . . . . . . . . . . . . . . . . . . . . . . . . . . . . . . .

SOURCES OF SUPPORT . . . . . . . . . . . . . . . . . . . . . . . . . . . . . . . . . . . . . . . . . . . . . .

DIFFERENCES BETWEEN PROTOCOL AND REVIEW . . . . . . . . . . . . . . . . . . . . . . . . . . .

NOTES . . . . . . . . . . . . . . . . . . . . . . . . . . . . . . . . . . . . . . . . . 118

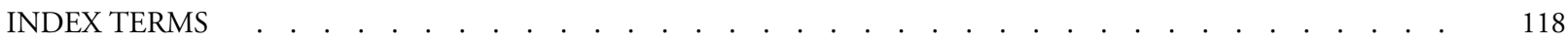

Non-pharmacological interventions for assisting the induction of anaesthesia in children (Review) 


\title{
[Intervention Review]
}

\section{Non-pharmacological interventions for assisting the induction of anaesthesia in children}

\author{
Anne Manyande ${ }^{1}$, Allan M Cyna ${ }^{2}$, Peggy Yip ${ }^{3}$, Cheryl Chooi ${ }^{2,4}$, Philippa Middleton ${ }^{5}$ \\ ${ }^{1}$ School of Psychology, Social Work and Human Sciences, University of West London, London, UK. ${ }^{2}$ Department of Women's \\ Anaesthesia, Women's and Children's Hospital, Adelaide, Australia. ${ }^{3}$ Department of Paediatric Anaesthesia, Starship Children's Hospital, \\ Auckland, New Zealand. ${ }^{4}$ Department of Acute Care Medicine, The University of Adelaide, Adelaide, Australia. ${ }^{5}$ Women's and \\ Children's Research Institute, The University of Adelaide, Adelaide, Australia
}

Contact address: Allan M Cyna, Department of Women's Anaesthesia, Women's and Children's Hospital, 72 King William Road, Adelaide, South Australia, 5006, Australia. allan.cyna@health.sa.gov.au.

Editorial group: Cochrane Anaesthesia Group.

Publication status and date: New search for studies and content updated (no change to conclusions), published in Issue 7, 2015.

Review content assessed as up-to-date: 28 August 2014.

Citation: Manyande A, Cyna AM, Yip P, Chooi C, Middleton P. Non-pharmacological interventions for assisting the induction of anaesthesia in children. Cochrane Database of Systematic Reviews 2015, Issue 7. Art. No.: CD006447. DOI: 10.1002/14651858.CD006447.pub3.

Copyright (C) 2015 The Cochrane Collaboration. Published by John Wiley \& Sons, Ltd.

\begin{abstract}
A B S T R A C T
Background

Induction of general anaesthesia can be distressing for children. Non-pharmacological methods for reducing anxiety and improving
\end{abstract} co-operation may avoid the adverse effects of preoperative sedation.

\section{Objectives}

To assess the effects of non-pharmacological interventions in assisting induction of anaesthesia in children by reducing their anxiety, distress or increasing their co-operation.

\section{Search methods}

In this updated review we searched CENTRAL (the Cochrane Library 2012, Issue 12) and searched the following databases from inception to 15 January 2013: MEDLINE, EMBASE, PsycINFO and Web of Science. We reran the search in August 2014. We will deal with the single study found to be of interest when we next update the review.

\section{Selection criteria}

We included randomized controlled trials of a non-pharmacological intervention implemented on the day of surgery or anaesthesia.

\section{Data collection and analysis}

At least two review authors independently extracted data and assessed risk of bias in trials.

\section{Main results}

We included 28 trials (2681 children) investigating 17 interventions of interest; all trials were conducted in high-income countries. Overall we judged the trials to be at high risk of bias. Except for parental acupuncture (graded low), all other GRADE assessments of the primary outcomes of comparisons were very low, indicating a high degree of uncertainty about the overall findings.

Non-pharmacological interventions for assisting the induction of anaesthesia in children (Review)

Copyright @ 2015 The Cochrane Collaboration. Published by John Wiley \& Sons, Ltd. 
Parental presence: In five trials (557 children), parental presence at induction of anaesthesia did not reduce child anxiety compared with not having a parent present (standardized mean difference (SMD) $0.03,95 \%$ confidence interval (CI) -0.14 to 0.20 ). In a further three trials (267 children) where we were unable to pool results, we found no clear differences in child anxiety, whether a parent was present or not. In a single trial, child anxiety showed no significant difference whether one or two parents were present, although parental anxiety was significantly reduced when both parents were present at the induction. Parental presence was significantly less effective than sedative premedication in reducing children's anxiety at induction in three trials with 254 children (we could not pool results).

Child interventions (passive): When a video of the child's choice was played during induction, children were significantly less anxious than controls (median difference modified Yale Preoperative Anxiety Scale (mYPAS) 31.2, 95\% CI 27.1 to 33.3) in a trial of 91 children. In another trial of 120 children, co-operation at induction did not differ significantly when a video fairytale was played before induction. Children exposed to low sensory stimulation were significantly less anxious than control children on introduction of the anaesthesia mask and more likely to be co-operative during induction in one trial of 70 children. Music therapy did not show a significant effect on children's anxiety in another trial of 51 children.

Child interventions (mask introduction): We found no significant differences between a mask exposure intervention and control in a single trial of 103 children for child anxiety (risk ratio (RR) $0.59,95 \%$ CI 0.31 to 1.11 ) although children did demonstrate significantly better co-operation in the mask exposure group (RR $1.27,95 \%$ CI 1.06 to 1.51 ).

Child interventions (interactive): In a three-arm trial of 168 children, preparation with interactive computer packages (in addition to parental presence) was more effective than verbal preparation, although differences between computer and cartoon preparation were not significant, and neither was cartoon preparation when compared with verbal preparation. Children given video games before induction were significantly less anxious at induction than those in the control group (mYPAS mean difference (MD) $-9.80,95 \%$ CI - 19.42 to -0.18) and also when compared with children who were sedated with midazolam (mYPAS MD - $12.20,95 \%$ CI -21.82 to -2.58 ) in a trial of 112 children. When compared with parental presence only, clowns or clown doctors significantly lessened children's anxiety in the operating/induction room (mYPAS MD -24.41, 95\% CI -38.43 to -10.48; random-effects, $\mathrm{I}^{2} 75 \%$ ) in three trials with a total of 133 children. However, we saw no significant differences in child anxiety in the operating room between clowns/clown doctors and sedative premedication (mYPAS MD -9.67, 95\% CI -21.14 to 1.80, random-effects, I2 66\%; 2 trials of 93 children). In a trial of hypnotherapy versus sedative premedication in 50 children, there were no significant differences in children's anxiety at induction (RR $0.59,95 \%$ CI 0.33 to 1.04$)$.

Parental interventions: Children of parents having acupuncture compared with parental sham acupuncture were less anxious during induction (mYPAS MD -17, 95\% CI -30.51 to -3.49) and were more co-operative (RR 1.59, 95\% CI 1.01 to 2.53 ) in a single trial of 67 children. Two trials with 191 parents assessed the effects of parental video viewing but did not report any of the review's prespecified primary outcomes.

\section{Authors' conclusions}

This review shows that the presence of parents during induction of general anaesthesia does not diminish their child's anxiety. Potentially promising non-pharmacological interventions such as parental acupuncture; clowns/clown doctors; playing videos of the child's choice during induction; low sensory stimulation; and hand-held video games need further investigation in larger studies.

\section{PLAIN LANGUAGE SUMMARY}

\section{Non-pharmacological interventions for assisting the induction of anaesthesia in children}

\section{Background}

The initial process of giving general anaesthesia (i.e. induction of anaesthesia) to children can be distressing for them and their parents. Children can be given a sedative medicine (premedication) to drink such as midazolam before anaesthesia is induced in order to help the child relax. However these drugs can have undesirable effects, such as possible airway obstruction before anaesthesia begins and during recovery. In addition behaviour changes may occur after the operation. Some non-drug alternatives have been tested to see if they could help children relax and co-operate at the beginning of their anaesthesia. This review aims to assess the effects of non-drug interventions such as hypnosis, acupuncture and video games in helping with the beginning of general anaesthesia in children

\section{Key findings}

Non-pharmacological interventions for assisting the induction of anaesthesia in children (Review)

Copyright $\odot 2015$ The Cochrane Collaboration. Published by John Wiley \& Sons, Ltd. 
We included 28 trials (2681 children under the age of 18 years and or their parents) with a large number of interventions (17) assessed.

The presence of parents at induction of the child's anaesthesia has been the most commonly investigated intervention (eight trials), but has not been shown to reduce anxiety or distress in children, or increase their co-operation during induction of anaesthesia.

Although parents should not be actively discouraged from being present if they prefer to do so, equally parents should not be encouraged to be present at their child's induction if they prefer not to do so.

Most commonly other interventions are given to the child (e.g. video games or hypnosis) but sometimes the intervention is given to the parent. One study of acupuncture for parents found that the parent was less anxious, and the child was more co-operative, at induction of anaesthesia. Another study of giving parents information, in the form of pamphlets or videos, failed to show an effect. In other studies looking at interventions for children, clowns or clown doctors, a quiet environment, video games and computer packages (but not music therapy) each showed benefits such as improved co-operation in the children.

\section{Quality of the evidence}

Many of the studies were of poor quality and too small to provide clear answers to the study question. However potentially promising non-pharmacological interventions such as parental acupuncture; clowns/clown doctors; playing videos of the child's choice during induction, pre-operative hypnosis and hand-held video games require further testing in future studies. Non-drug interventions that might help parents relax need further study, as there is some evidence that more relaxed parents may improve their child's anaesthesia induction experience.

Non-pharmacological interventions for assisting the induction of anaesthesia in children (Review) 


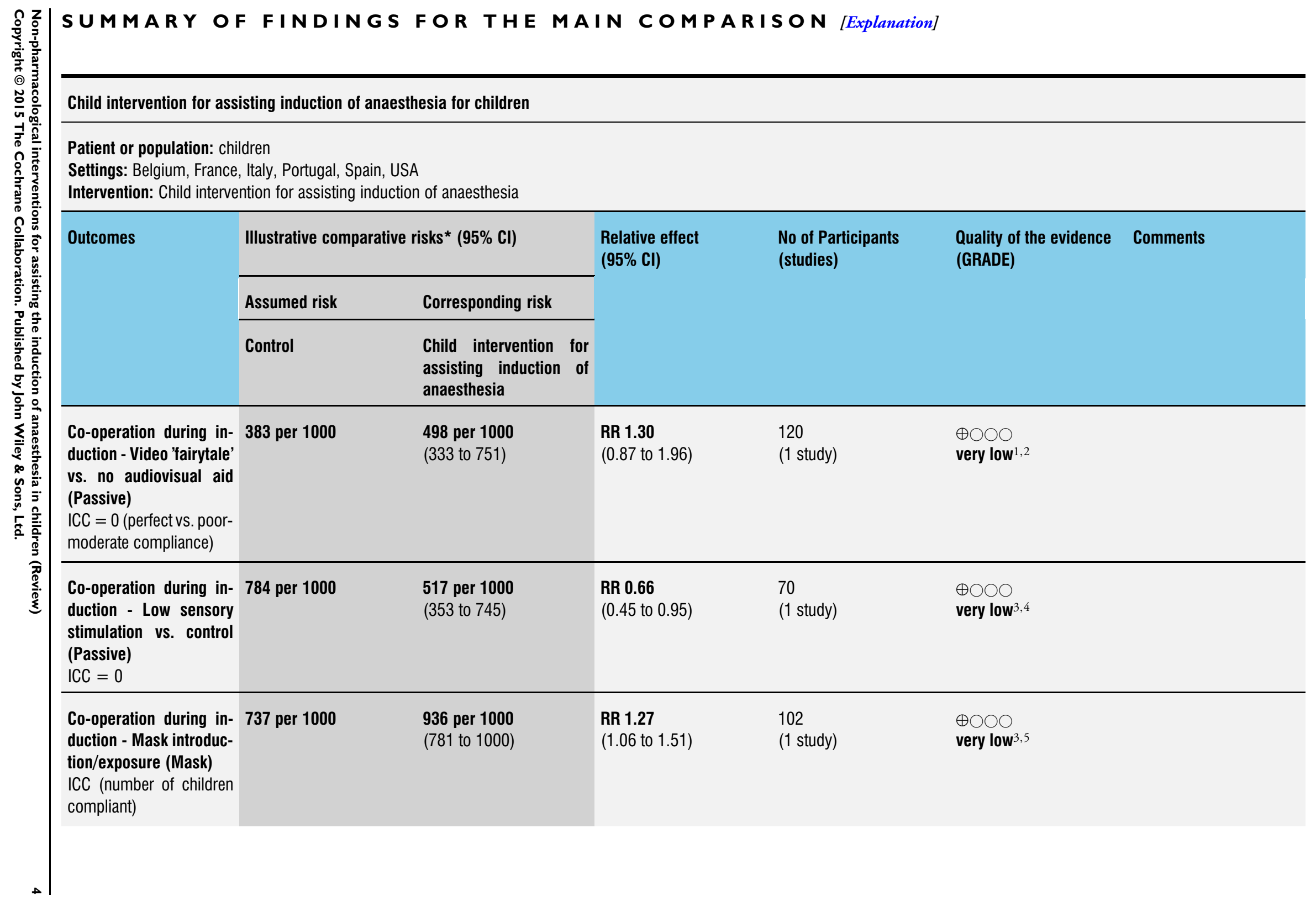


Anxiety during induction The mean anxiety during The mean anxiety during - Video game vs. mida- induction - video game induction - video game zolam (Interactive)

mYPAS. Scale from: 1 to tive) in the control groups

100

53.9 points

midazolam (interac-

ive) in the intervention

groups was

12.2 lower

(21.82 to 2.58 lower)

Co-operation during in- The mean co-opera- The mean co-opera-

duction - clowns/clown tion during induction - tion during induction -

doctors vs. parental clowns/clown doctors vs. clowns/clown doctors vs.

presence (Interactive) parental presence (inter- parental presence (inter-

SAM - arousal. Scale active) in the control active) in the intervention

from: 1 to 5.

groups was

groups was

3.36 points $\quad \mathbf{1 . 7 0}$ lower

(2.33 to 1.07 lower)

\section{Anxiety during induction 667 per 1000}

393 per 1000

- hypnosis vs. midazo-

(220 to 693)

lam (Interactive)

mYPAS $<24$

*The basis for the assumed risk (e.g. the median control group risk across studies) is provided in footnotes. The corresponding risk (and its $95 \%$ confidence interval) is based on the assumed risk in the comparison group and the relative effect of the intervention (and its $95 \% \mathrm{Cl}$ ).

Cl: Confidence interval; RR: Risk ratio;

GRADE Working Group grades of evidence

High quality: Further research is very unlikely to change our confidence in the estimate of effect.

Moderate quality: Further research is likely to have an important impact on our confidence in the estimate of effect and may change the estimate.

Low quality: Further research is very likely to have an important impact on our confidence in the estimate of effect and is likely to change the estimate.

Very low quality: We are very uncertain about the estimate.

${ }^{1}$ Study lacked information regarding selection, performance, attrition and reporting bias

${ }^{2}$ The sample size was small $(\mathrm{n}=120)$

${ }^{3}$ Study had limited information related to selection, detection and reporting bias

${ }^{4}$ The sample size was small $(\mathrm{n}=70)$

${ }^{5}$ Study had a small sample size $(n=103)$

v $\quad{ }^{6}$ The study lacked information on selection, detection and reporting bias and detection bias was high

(1 study) very low 6 ,

70

(1 study) very low




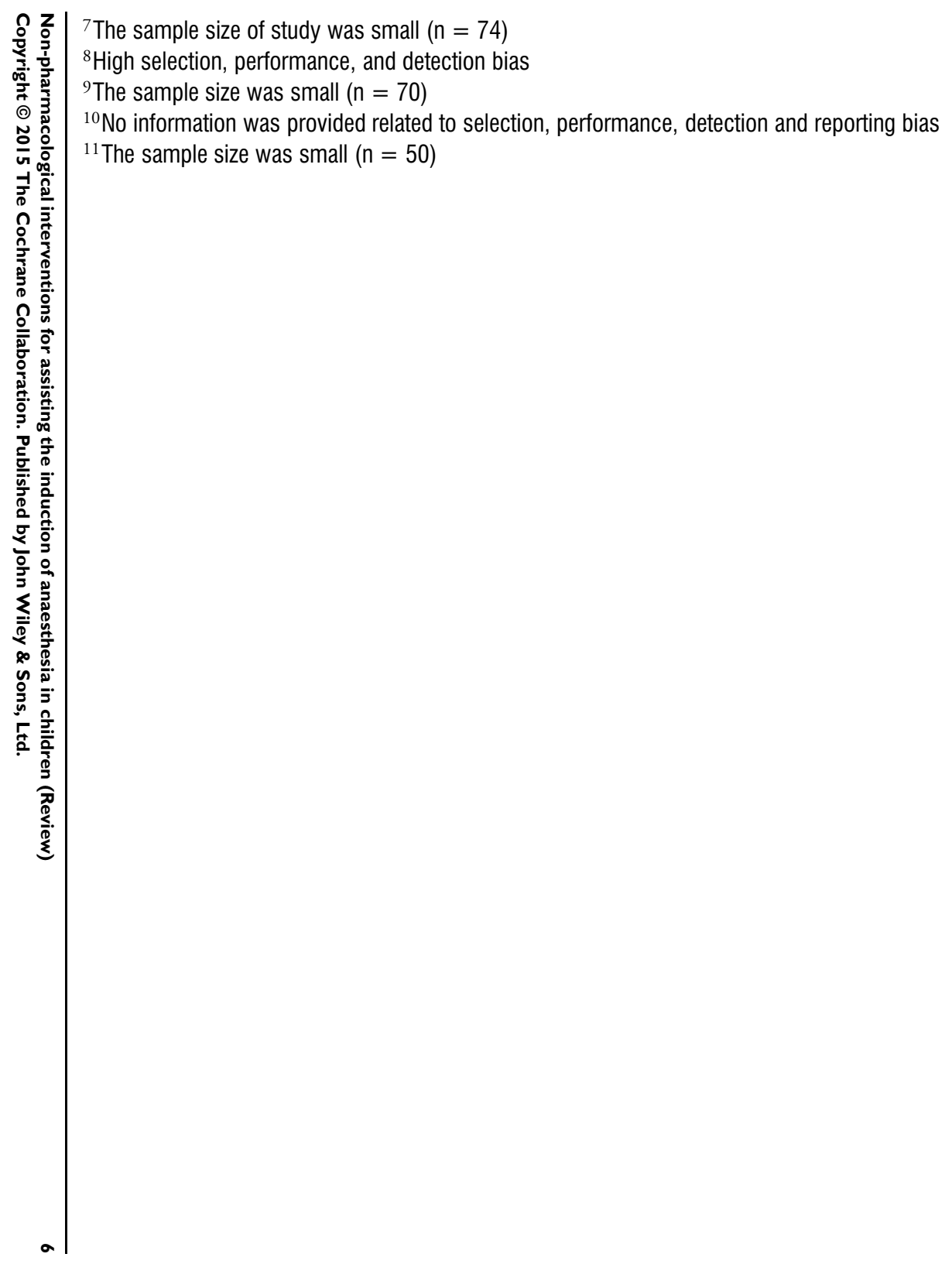




\section{B A C K G R O U N D}

The initial introduction of a general anaesthetic is known as 'the induction of anaesthesia' and can be stressful for children. Disrupted routines, unfamiliar faces, separation from family, hospital procedures and uncertainty about anaesthesia or surgery can be harrowing for patients (Brennan 1994; Feldman 1998). Minimizing anxiety and distress at the time of anaesthetic induction may therefore reduce adverse psychological and physiological outcomes (Greenberg 1996; Holm-Knudsen 1998).

\section{Induction of anaesthesia}

General anaesthesia may be induced by inhaled or intravenous routes, although the former is most often used for children. Some anaesthetists believe that a mask or inhalational induction is less psychologically terrifying to children (Aguilera 2003), since children are generally thought to have a fear of needles (Van den Berg 2005a; Van den Berg 2005b). Inhalational anaesthesia is induced with a volatile agent in air or nitrous oxide mixed with supplemental oxygen, usually through a breathing circuit (tubing attached to a face mask).

\section{Distress and anxiety in children undergoing anaesthesia}

Most children find induction of general anaesthesia before surgery very stressful (Kain 2005; Wollin 2003), and parental stress can be easily transmitted indirectly to a child (Bevan 1990). The level of a child's anxiety varies with age, maturity, temperament and previous anaesthetic experiences (Davidson 2006; Stargatt 2006). A previously co-operative child may become apprehensive and resist the application of the mask on their face or become upset when the anaesthetic circuit is brought close to them. Children may protest, fight or try and escape during this period (Greenberg 1996), which may prolong the induction and be emotionally traumatic for the child, parents and theatre staff (Holm-Knudsen 1998; Iacobucci 2005; Kain 1999b). Preoperative distress has also been found to be associated with postoperative agitation and negative behaviours (Stargatt 2006). The consequences of preoperative anxiety and distress may extend beyond the perioperative period (Kain 1996a; Kotiniemi 1997).

\section{Pros and cons of premedication}

Sedative medications can alleviate preoperative anxiety, facilitate separation from relatives or friends, and reduce distress at induction (Kain 1999a). However, children may refuse the drug, the drug may fail or even cause adverse reactions such as disinhibition and dysphoria, postoperative behavioural changes and prolonged recovery times (Ullyot 1999). Other disadvantages include safety concerns (airway obstruction or respiratory depression in unmonitored situations); costs of pharmacy; additional nursing staff and equipment; list delays; and delayed discharge (Cray 1996). As a result non-pharmacological methods have been sought.

\section{Interventions}

A wide range of non-pharmacological interventions have been used to reduce perioperative distress and encourage co-operation in children. These can be broadly categorized as:

- psychological (cognitive or behavioural);

- environmental;

- equipment modification;

- social interventions, including communication.

\section{Rationale for the review}

Previous systematic reviews have examined the effects of patient education on preoperative anxiety (Lee 2003; Lee 2005) and the effect of preoperative fasting on perioperative complications in children (Brady 2009). A Cochrane review (Uman 2013) has evaluated psychological interventions for needle-related procedures in children and adolescents, which includes patients presenting for intravenous induction of anaesthesia. Another Cochrane review (Pillai Riddell 2011) has investigated non-pharmacological interventions for needle-related procedural pain in neonates and infants.

There has been no comprehensive, systematic review of the effects of non-pharmacological interventions administered in hospital to assist the induction of anaesthesia in children. In addition, information about which particular interventions or combinations of interventions are most effective in this setting has not been assessed. This is an update of the 2009 version of this review (Other published versions of this review).

\section{O B J E C T IVES}

To assess the effects of non-pharmacological interventions in assisting induction of general anaesthesia in children by reducing their anxiety, distress or increasing their co-operation.

\section{METHODS}

\section{Criteria for considering studies for this review}

\section{Types of studies}

We included randomized or quasi-randomized controlled trials. 


\section{Types of participants}

We included children or adolescents aged less than 18 years presenting for induction of general anaesthesia, except where the intent is solely intravenous induction.

\section{Types of interventions}

We included any non-pharmacological intervention implemented on the day of surgery compared with any other intervention, such as a midazolam premedication, or no treatment. Studies may assess a single non-pharmacological intervention or a combination of non-pharmacological interventions, and may compare them with other non-pharmacological interventions; pharmacological interventions (e.g. midazolam or ketamine premedication); or with usual care.

We included the following types of interventions:

- psychological (cognitive or behavioural) interventions: such as distraction, cognitive tasks, hypnosis, virtual reality;

- environmental interventions: use of induction room, patient retains own clothing;

- equipment modification: disguised anaesthesia delivery system;

- social interventions: parental or support person presence, number of medical staff in the room at induction;

- anaesthetist communication: tone of voice, language (neutral or positive).

We considered interventions with parents or accompanying persons if the child's anxiety, distress or co-operation at induction were outcome measures.

\section{Types of outcome measures}

\section{Primary outcomes}

1. The number of children with distress or anxiety, or the extent of presence or absence of distress or anxiety (as defined and measured by the authors of the study) during induction of general anaesthesia;

2. The number of children who co-operate, or the extent of presence or absence of co-operation (as defined and measured by the authors of the study) during induction of general anaesthesia.

\section{Secondary outcomes}

1. The number of caregivers with anxiety (as defined and measured by the authors of the study);

2. The time taken for anaesthetic induction;

3. Change from planned inhalational to intravenous (iv) induction;

4. The number of children with increased anaesthetic requirements;

5. Risk of emergence delirium;
6. The number of children with negative behavioural changes (as defined and measured by the authors of the study) in the immediate postoperative period (while the child is in recovery) e.g. distress in recovery;

7. The number of children co-operating or without distress on entering the room, or area, where anaesthesia induction is to take place (as defined and measured by the authors of the study);

8. The number of children or caregivers satisfied with care (as defined and measured by the authors of the study).

\section{Outcome Measures}

We defined these as any type of negative affect or behaviour associated with the induction of anaesthesia (e.g. anxiety, stress, fear, unco-operative behaviour) which can be assessed by psychological measures of behaviour, anxiety or distress such as the Yale Preoperative Anxiety Scale for measuring anxiety in young children (Kain 1997); the Induction Compliance Checklist for assessing co-operation during induction (Kain 1998); and the Vernon Post Hospitalization Behavior Questionnaire (Stargatt 2006).These scales may provide a measure of the extent of anxiety or distress.

\section{Search methods for identification of studies}

\section{Electronic searches}

We searched the Cochrane Central Register of Controlled Trials (CENTRAL, the Cochrane Library 2013, Issue 1, see Appendix 1). We also searched the following complementary medicine, nursing, psychology and medical databases: MEDLINE (Ovid SP, 1966 to January 15, 2013, see Appendix 2), EMBASE (Ovid SP, 1980 to January 15, 2013, see Appendix 3), PsycINFO (Ovid SP, 1995 to January 15, 2013, see Appendix 4), CINAHL (EBSCO host, 1982 to January 2, 2012, see Appendix 5), Dissertation Abstracts (1988 to 14th December 2008), and ISI Web of Science (1990 to January 15, 2013, see Appendix 6), and reran the searches on 28 August 2014.

The original search was performed on 14th December 2008 (Yip 2009).

We searched MEDLINE using the MeSH headings and text words and adapted this strategy for the other databases as appropriate.

After piloting various search strategies, we largely omitted terms to describe the possible interventions, since our piloting revealed that such interventions were not always indexed, or indexed consistently.

We searched registers of ongoing trials such as the Meta-Register of Trials (www.controlled-trials.com). 


\section{Searching other resources}

We located additional references by searching the reference and citation lists of relevant papers and adjusted our search strategy accordingly.

We searched for unpublished studies and dissertations for possible inclusion in this review by contacting researchers through email list-servers such as the Paediatric Anaesthesia Conference (PAC) list-server; the Society of Pediatric Psychology list-server; and by contacting experts and trialists through e-mail and direct communication.

We did not limit the search by language or publication status.

\section{Data collection and analysis}

\section{Selection of studies}

We reviewed the titles and abstracts of studies identified from the search. From the full text of potentially relevant articles, four review authors (PM, AM, PY, AVC) independently assessed each trial for inclusion in terms of population, intervention, outcome, and study design. We resolved disagreements regarding inclusion of potentially eligible studies by consensus or third author arbitration (AMC).

We excluded studies:

- of prehospital preparation programmes (hospital tours, modelling, stress-point preparation);

- of non-hospital settings;

- of patient education or media-based interventions prior to the day of surgery which have been addressed elsewhere (Lee 2003; Lee 2005);

- assessing the effects of non-pharmacological interventions to assist with intravenous induction of anaesthesia, as this is being considered elsewhere (Uman 2013; Pillai Riddell 2011);

- assessing the effects of fasting preoperatively as this is being considered elsewhere (Brady 2009).

\section{Data extraction and management}

At least two review authors independently extracted the following data (using a form designed for this specific review):

- study participants: age, gender, previous anaesthetics, inclusion and exclusion criteria;

- study methods: objective, design, randomization, recruitment, blinding (participant, assessor, other staff, statistician), methods of analysis, follow-up;

- interventions: intervention type, timing (when intervention used), co-interventions, control (usual care description);
- outcomes: outcome type, author's definition of outcome, measurement tool (including validity), timing of assessment;

- results: means, standard deviations, numbers of events, proportions;

- study withdrawals or losses to follow-up, with reasons.

We contacted one study author to clarify information and provide additional data. When we had completed the data extraction forms, two review authors entered the data into Review Manager 5 software (RevMan 5.3) and a third review author checked them.

\section{Assessment of risk of bias in included studies}

Four authors (PM, AM, PY, AVC) independently examined the methodological quality of trials in relation to randomization; allocation concealment; outcome assessment; blinding of outcome assessments; losses to follow-up and treatment of withdrawals. We graded each item as 'low risk', 'high risk' or 'unclear'; or gave actual numbers in the case of losses to follow-up. Due to the nature of the interventions, such as parental presence, blinding of the interventions was not possible. We therefore included studies without blinding of individuals administering and receiving interventions for inclusion.

\section{Measures of treatment effect}

In studies that reported dichotomous data, we calculated risk ratios (RRs) with $95 \%$ confidence intervals (CIs). For continuous outcomes (such as anxiety) we calculated mean differences (MDs) and $95 \%$ CIs or standardized mean differences (SMDs). When scales of outcomes are in different directions (e.g. scales with a low score for low anxiety and others with a high score for low anxiety), we subtracted means from the highest value in the scale. We analysed outcomes such as anxiety, distress and co-operation using mean differences where possible.

\section{Assessment of heterogeneity}

We estimated heterogeneity using the $\mathrm{I}^{2}$ statistic (Higgins 2002). Where there was moderate heterogeneity $\left(\mathrm{I}^{2}>50 \%\right)$ we presented data with a random-effects model.

\section{Assessment of reporting biases}

We attempted to assess possible publication bias by visual inspection of funnel plots, with asymmetry of the funnel plots indicating possible publication bias.

\section{Data synthesis}

We synthesized and analysed data using RevMan 5.3. 


\section{Subgroup analysis and investigation of heterogeneity}

We had planned to conduct subgroup analyses to compare:

- different age groups such as: infant or toddler (0 to 2 years), children (3 to 12 years) and adolescent (3 to 17 years);

- inhalational and intravenous methods of induction (for studies where both methods have been used);

- whether the outcomes were measured at the time of induction, before induction or after induction.

However there were insufficient data to do this.

\section{Sensitivity analysis}

We had intended to perform the following sensitivity analyses, but there were insufficient data to complete this:

- for randomized and quasi-randomized trials;

- for trials with and without clear allocation concealment;

- in trials where anaesthetic agents at induction are controlled and not controlled for.

\section{R E S U L T S}

\section{Description of studies}

\section{Results of the search}

The original review (Yip 2009) included 17 trials. We included 11 new trials for this update of the review, making a total of 28 included trials. We reran the search in August 2014. We will deal with the single study found to be of interest when we next update the review. (see Figure 1).

\section{Included studies}

The 28 included trials investigated 17 comparisons involving 2681 children or their parents, or both. See Characteristics of included studies for detailed descriptions.

\section{Settings}

Fifteen of the trials were conducted in the United States of America; seven in Europe; two in the UK, one in Japan, two in Turkey, and two in Canada.

\section{Interventions}

Of the 28 included trials, 12 trials primarily addressed parental presence (four new trials for this update); 13 addressed child or child/parent interventions (seven new trials for this update); and three addressed parental interventions, with some trials addressing more than one area.

Parental presence
- parental presence versus no parental presence (Akinci 2008; Arai 2007; Bevan 1990; Kain 1996b; Kain 1998; Kain 2000;

Kain 2003; Kain 2007; Palermo 2000; Wright 2010);

- one parent versus two parents (Kain 2009);

- parental presence versus sedative premedication (Arai 2007; Kain 1998; Kain 2007; Kazak 2010);

- parental presence plus sedative premedication versus no parental presence (Kain 2003).

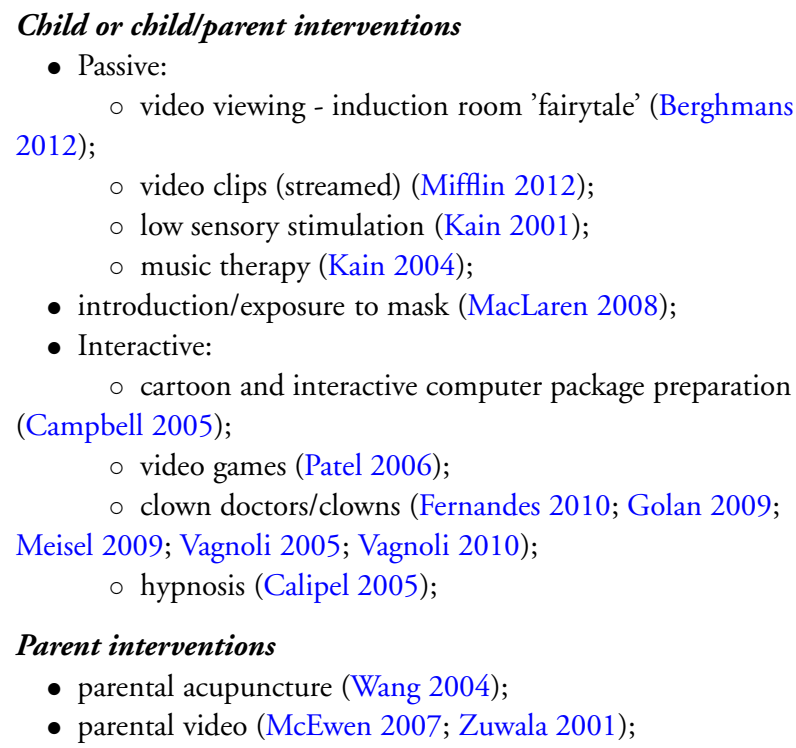

Some trials in which parental presence was not the primary focus of the intervention controlled for this factor by having parents present (Campbell 2005; McEwen 2007; Patel 2006; Vagnoli 2005; Wang 2004; Wang 2005; Zuwala 2001; Vagnoli 2010); or not present (Kain 2004; Kain 2001; Wang 2008) during the induction of anaesthesia. One trial did not control for parental presence (Calipel 2005) and one trial used parents as a rescue intervention for anxiety in the control group (Kain 2003).

\section{Participants}

The included trials investigated children aged up to 17 years and down to one month. Most trials excluded ASA III \& IV (American Society of Anesthesiologists grading of anaesthesia risk as high) children and those with a history of chronic illness, preterm birth and developmental delay. Eight trials excluded children who had received previous surgery or anaesthesia or both (Arai 2007; Campbell 2005; Golan 2009; Kain 1996b; Meisel 2009; Vagnoli 2005; Vagnoli 2010; Zuwala 2001). Calipel 2005 excluded those who had been hospitalized six months prior to the study and Patel 2006 excluded children with repeated surgeries. Two studies excluded children with language barriers (Meisel 2009; Mifflin 2012). Berghmans 2012 and MacLaren 2008 did not report any exclusion criteria.

Most children received inhalational anaesthesia with oxygen, nitrous oxide and sevoflurane. Halothane was used in two studies (Kain 1996b; Kain 1998). Nine trials failed to describe the 
induction technique (Berghmans 2012; Bevan 1990; Fernandes 2010; Golan 2009; MacLaren 2008; McEwen 2007; Meisel 2009;

Palermo 2000; Wright 2010).

\section{Outcome assessments}

Most studies used versions of the Yale Preoperative Anxiety Scale (YPAS, mYPAS) to assess anxiety of children. Other scales used were: hospital fear inventory; global mood scale; visual analogue scale (VAS); clinical anxiety rating scale; procedural behavioural rating scale; and the child behaviour scale. One study measured serum cortisol as a physiological indicator for anxiety (Kain 1996b). Co-operation of children was reported in 11 trials. Eight trials (Berghmans 2012; Kain 1998; Kain 2000; Kain 2001; Kain 2004; Kain 2009; MacLaren 2008; Wang 2004) used the induction compliance checklist (ICC); two trials used coping VAS (Campbell 2005; Kain 1996b) and one trial measured child cooperation by quality of mask induction (Arai 2007).

Parental anxiety was assessed using state trait anxiety inventory (STAI) in all but one of the 11 studies reporting this outcome. The other study reported parental anxiety using the Amsterdam Preoperative Anxiety and Information Scale (APAIS). Three studies (Kain 1996b; Kain 2003; Zuwala 2001) measured blood pressure, heart rate, and skin conductance as physiological indicators of parental anxiety.

Data on immediate postoperative behavioural changes in children were described in three studies employing two different scales: excitement scale (Kain 1996b; Kain 2000) and the emergence behaviour scale (Kain 2007). Others collected data on behavioural changes beyond day one from post-hospital behavioural questionnaires. One study reported postoperative nausea and vomiting (PONV) in the postoperative unit (PACU), on days 1, 2 and 3 at home (Fortier 2010a). Parental satisfaction was measured by a 100 mm VAS (Kain 1996b) and Likert scales (Kain 1998; Palermo 2000).

Data on other outcomes of interest collected were: risk of adverse effects; time to discharge; analgesia requirements, nausea and vomiting; and health professionals' opinion regarding presence of clowns.

\section{Excluded studies}

The most common reasons for the 26 exclusions (16 new exclusions for this update) included method of induction not being inhalational and intervention applied prior to the day of surgery (see Characteristics of excluded studies).

\section{Risk of bias in included studies}

With no trial demonstrating low risk of bias allocation concealment combined with the inability to blind participants and personnel in most trials, we judged the overall risk of bias across the 28 included trials to be high (see Figure 2; Figure 3).

\section{Allocation}

\section{Sequence generation}

Most trials ( $\mathrm{n}=16)$ used low risk of bias methods of sequence generation, such as computer-generated randomization; methods were unclear in nine trials and three trials were quasi-randomized.

\section{Allocation concealment}

We could not classify any trial as having reported low risk of bias allocation concealment. In line with inadequate sequence generation, three trials also had high risk of bias allocation concealment. Of the remaining 25 trials, most $(n=17)$ did not report the method of allocation concealment.

\section{Blinding}

Blinding was often not possible because most interventions were visible to investigators and participants, and we judged only one trial to have low risk of bias blinding of investigators and participants (Wang 2004). Seven trials reported blinded assessment of outcomes.

\section{Incomplete outcome data}

Losses to follow-up were generally small, as would be expected where most outcomes could be assessed soon after the intervention, with none of the 28 trials judged to be at high risk of bias for this component.

\section{Selective reporting}

We judged only one trial to be at high risk of reporting bias, as it reported only one outcome. However we rated many of the trials as unclear for this component.

\section{Other potential sources of bias}

We judged only one trial to be at high risk of other bias, due to a baseline imbalance in numbers randomized to each group.

\section{Effects of interventions}

See: Summary of findings for the main comparison Child intervention for assisting induction of anaesthesia for children; Summary of findings 2 Parent intervention for assisting induction of anaesthesia for children; Summary of findings 3 Parental presence for assisting the induction of anaesthesia for children 


\section{Parental presence}

Twelve trials investigated the effects of parental presence on anxiety/distress associated with induction in children in several types of comparisons (Akinci 2008; Arai 2007; Bevan 1990; Kain 1996b; Kain 1998; Kain 2000; Kain 2003; Kain 2007; Kain 2009; Kazak 2010; Palermo 2000; Wright 2010).

\section{I.I Parental presence versus no parental presence}

\section{Primary outcomes}

Two of the five studies contributing data to this outcome deployed the commonly used mYPAS. The other three studies each used a different scale (Global mood score, Child Behaviour Scale and a four-point scale where one indicated agitated and four indicated 'Sleeping'). These five trials (557 children) each showed no differences between parental or no parental presence in anxiety or distress of their children during induction. When pooled using standardized mean differences, there was no clear overall difference between parental presence and no parental presence (SMD 0.03, $95 \%$ CI -0.14 to 0.20 : Analysis 1.1 ). In another two trials (187 children), anxiety during induction (measured as median and range by several methods) was also not significantly different between parental or no parental presence (Analysis 1.2). Kain 2003 reported no significant difference in children's anxiety whether parents were present or absent, but gave no further details.

A subgroup analysis of Bevan 1990 indicated that an anxious parent was more likely to have a child who was anxious during induction if that parent was present (significant subgroup interaction test $\mathrm{Chi}^{2}$ 3.92, $\mathrm{P}$ value $=0.05, \mathrm{I}^{2}=75 \%$; Analysis 1.3 ) .

We found no significant difference in child co-operation during induction whether or not parents were present, either as poor compliance with ICC > 6 (RR $0.64,95 \%$ CI 0.23 to 1.77 ; one trial of 55 children) or when measured in other ways (three trials with a total of 225 children); Analysis 1.4 .

\section{Secondary outcomes}

Anxiety/distress before induction: Children in the no-parentalpresence group had significantly higher (worse) mYPAS scores at the time of separation (leaving for the operating room) compared with the parental-presence group where presumably there was no separation (MD -12.16, 95\% CI -19.90 to -4.42 ; one trial of 61 children; Analysis 1.5).

Parental presence had no significant effects overall on parental anxiety on the day of surgery (Analysis 1.6; Analysis 1.7). We could not pool the five trials contributing data due to the different methods used to measure parental anxiety.

As above for children's anxiety, a subgroup analysis of Bevan 1990 indicated that an anxious parent was more likely to remain anxious during the child's induction compared with the anxiety ratings of calm parents who had similar anxiety scores, whether or not they were present (significant subgroup interaction test $\mathrm{Chi}^{2}$ 5.90, $\mathrm{P}$ value $=0.02, \mathrm{I}^{2}=83 \%$; Analysis 1.8). However in this trial, parents present at induction had higher anxiety one week after their child's operation (Analysis 1.9) when results for calm and anxious parents were combined.

In one trial (Kain 2000), when all children were premedicated with midazolam, parents were significantly less anxious when they were present during induction compared with parents not present; Analysis 1.10.

Emergence delirium/behaviour did not differ significantly depending on whether a parent was present or not, although In one trial where all children were premedicated with midazolam (Arai 2007), emergence behaviours were improved when the mother held her child (four trials of 324 children; Analysis 1.11; Analysis 1.12).

There were no significant differences between parental presence and no presence for time taken for induction (Analysis 1.13); or negative behaviour postoperatively after discharge (at one week, two weeks, and six months) Analysis 1.14; Analysis 1.15.

In three trials measuring parental satisfaction in a number of ways, we found no important differences between parental presence (Analysis 1.16; Analysis 1.17), although in a trial where all children were premedicated with midazolam, parents who were present were significantly more satisfied than parents not present during their child's induction; Analysis 1.18).

\section{I.2 Two parents versus one parent}

\section{Primary outcomes}

In a single trial of 58 children (Kain 2009), there were no differences in children's anxiety (measured by mYPAS) or compliance (ICC > 6 RR 1.88, 95\% 0.61 to 5.72) at induction, whether one or two parents were present; Analysis 2.1 and Analysis 2.2 respectively.

\section{Secondary outcomes}

In the same trial, parental anxiety after leaving the operating room was significantly lower in the two-parent group than the oneparent group (STAI -8.90, 95\% CI -15.23 to -2.57); Analysis 2.3.

\section{I.3 Parental presence versus sedative medication}

Four trials (Arai 2007; Kain 1998; Kain 2007; Kazak 2010) compared parental presence with sedative medication.

\section{Primary outcomes}

In a single trial of 50 children (Kain 2007), midazolam was superior in reducing anxiety of children during induction compared with parental presence (MD 10 fewer points mYPAS, 95\% CI 2.91 to 17.09; Analysis 3.1). Two other trials (102 children) 
only reported $\mathrm{P}$ values for this outcome, with both trials finding a significant reduction in anxiety at introduction of the mask for midazolam compared with parental presence; Analysis 3.2.

Co-operation during induction showed conflicting results in two trials. In Kain 1998, the difference between parental presence and midazolam was not significantly different for children with an ICC $>6$ (RR 12.47, 95\% 0.72 to 216.20; 62 children; Analysis 3.3). Arai 2007 reported that quality of mask induction was superior with midazolam as compared with parental presence, $\mathrm{P}$ value $=$ 0.05, 39 children; Analysis 3.4.

\section{Secondary outcomes}

Midazolam shortened the time taken for induction by $0.6 \mathrm{~min}$ utes (95\% CI 0.36 to 0.84 minutes) compared with parental presence in one trial of 62 children (Kain 1998); Analysis 3.6.

In Kain 1998, there were no significant differences in parental anxiety (Analysis 3.5) or parental satisfaction (Analysis 3.10). Emergence behaviour was reported in different ways in three trials (total of 293 children), all finding no significant difference between parental presence and midazolam; Analysis 3.7; Analysis 3.8 .

Kain 1998 found no significant difference in negative postoperative behaviour at two weeks; Analysis 3.9.

\section{I.4 Parental presence (plus midazolam) versus no parental presence}

\section{Primary outcomes}

In a single trial of 25 children (Kain 2003), children were significantly less anxious during induction if they received midazolam as premedication and were accompanied by their parents, compared with no parental presence; $P$ value $=0.023$ (no further details reported).

\section{Secondary outcomes}

However, the addition of premedication for the child had no significant impact on parental anxiety compared with no parental presence, as measured physiologically; Analysis 4.1; Analysis 4.2.

\section{Child interventions}

\section{I Child interventions - passive}

Sixteen different interventions for children undergoing anaesthesia were assessed in 14 trials.

\section{I.I Video viewing (induction room 'fairytale')}

\section{Primary outcomes:}

In a single trial of 120 children and one of their parents (Berghmans 2012), child co-operation at induction did not differ significantly between the video-viewing and control groups (RR for perfect compliance $1.30,95 \%$ CI 0.87 to 1.96 ; Analysis 5.1).

\section{Secondary outcomes:}

When measured as a binary outcome, parental anxiety (STAI $\geq$ 46) did not show a difference between the video-viewing and novideo group either in the holding bay or after leaving the operating theatre (RR $0.55,95 \%$ CI 0.30 to 1.00 ; and RR $1.00,95 \%$ CI 0.70 to 1.43 respectively) Analysis 5.2. However parental anxiety (as measured by APAIS $\geq 13$ ) significantly favoured the videoviewing group at both time points (RR $0.52,95 \%$ CI 0.28 to 0.99 ; and RR $0.46,95 \%$ CI 0.26 to 0.83 respectively) Analysis 5.3. Both STAI (state) and APAIS (state) indicated lower parental anxiety in the video-viewing group, although the APAIS (information) scale was not significantly different between the viewing and nonviewing groups (Analysis 5.4; Analysis 5.5).

\subsubsection{Video clips (streamed)}

Mifflin 2012 compared a video distraction technique (playing a video clip of the child's choice) compared with no video clip during induction of anaesthesia.

\section{Primary outcomes:}

The mYPAS scores between the video and no-video groups at anaesthesia induction indicated significantly lessanxiety in the video group (median difference 31.2, 95\% CI 27.1 to 33.3 ; 91 children).

\subsubsection{Low sensory stimulation}

\section{Primary outcomes:}

Children in the low sensory stimulation group were significantly less anxious than control children on introduction of the anaesthesia mask, $\mathrm{P}$ value $=0.003$ in one trial of 70 children (Kain 2001). They were also more likely to be co-operative during induction in the low sensory stimulation group in one trial: RR for ICC of zero: $0.66,95 \%$ CI 0.45 to 0.95 ; Analysis 6.1). 


\section{Secondary outcomes:}

In this trial, children in the low sensory stimulation group were significantly less anxious than control children on entrance to the operating room ( $P$ value $=0.03$ ). Postoperative negative behavioural changes were reported not to differ between groups. Parental anxiety measured by STAI in this trial did not demonstrate any statistical differences in the low sensory stimulation group compared with control (MD -2, 95\% CI -9.03 to 5.03; Analysis $6.2)$.

\subsubsection{Music therapy}

\section{Primary outcomes:}

Kain 2004 failed to demonstrate any statistical differences in anxiety in the group who received music therapy ( 51 children) compared with the control group (38 children). A subgroup of 21 children who received music therapy from one particular therapist were less anxious on entering induction area $(P$ value $=0.047)$. There were no differences in compliance of children who received music therapy compared with those who did not $(P$ value $=0.28)$. However, when music therapy was compared with midazolam in this trial, premedicated children were significantly less anxious ( $P$ value $=0.015 ; 85$ children), as well as more compliant during induction of anaesthesia.

\subsection{Child interventions - Introduction/exposure to mask}

\subsection{Introduction/exposure to mask}

\section{Primary outcomes:}

There were no significant differences between a mask exposure intervention and control in a single trial of 103 children (MacLaren 2008) for child anxiety post-intervention (RR 6.44, 95\% CI 0.78 to 53.23; Analysis 7.1) or during induction (RR 0.59, 95\% CI 0.31 to 1.11 ; Analysis 7.1 ). However, children did demonstrate significantly better co-operation in the mask exposure group (RR $1.27,95 \%$ CI 1.06 to 1.51 ; Analysis 7.2).

\section{Secondary outcomes:}

In this trial, parental anxiety (STAI: trait) did not show significant differences between the mask exposure and control groups (MD -1.06, $95 \%$ CI -3.35 to 1.23; Analysis 7.3).

\subsection{Child interventions - interactive}

\subsection{Cartoon and interactive computer package preparation}

In a three-arm trial of 168 children, Campbell 2005 compared preparation, with a cartoon or by interactive computer package, with verbal preparation.

\section{Primary outcomes:}

Co-operation during induction was measured by coping VAS and reported as median and range. Preparation with interactive computer packages (in addition to parental presence) was more effective than verbal preparation (Analysis 8.1), although differences between computer preparation and cartoon preparation were not significant (Analysis 10.1) and neither was cartoon preparation when compared with verbal preparation (Analysis 9.1).

\section{Secondary outcomes:}

Negative behavioural changes were also measured by coping VAS and reported as median and range. The computer-prepared group showed fewer negative behavioural changes in the recovery area compared with the cartoon group (Analysis 10.2), with the other two comparisons (computer versus verbal preparation (Analysis 8.2) and cartoon versus verbal preparation (Analysis 9.2)) not showing significant differences.

\subsubsection{Video games}

Patel 2006 was a three-armed trial of 112 children, comparing video games, midazolam and controls.

\section{Primary outcomes:}

Children in the video-game group were significantly less anxious at induction than those in the control group (mYPAS MD -9.80, 95\% CI -19.42 to -0.18 ; Analysis 11.1) and also compared with children who were sedated with midazolam (mYPAS MD -12.20, 95\% CI -21.82 to -2.58; Analysis 12.1).

\section{Secondary outcomes:}

We found no differences in postoperative behaviour scores when children in the video-game group were compared with controls (Analysis 11.2) or with midazolam (Analysis 12.2).

\subsubsection{Clown doctors/clowns}

Five trials examined the effects of clowns or clown doctors on children's anxiety (Fernandes 2010; Golan 2009; Meisel 2009; Vagnoli 2005; Vagnoli 2010). 


\section{Primary outcomes (compared with parental presence):}

When compared with parental presence only, clowns or clown doctors significantly lessened children's anxiety in the operating/ induction room (mYPAS MD $-24.41,95 \%$ CI -38.43 to -10.48 ; random-effects, $\mathrm{I}^{2}=75 \%$ ) in three trials with a total of 133 children (Analysis 13.1).

However, this reduction with clowns/clown doctors present was not seen in one of these trials (Golan 2009) measuring anxiety also at mask introduction (mYPAS MD 8.30, 95\% CI -2.68 to 19.28; 43 children; Analysis 13.1). Fernandes 2010 measured children's anxiety during induction using the Chidren's Surgery Worries Questionnaire (CSWQ), finding significantly less anxiety for each of the CSWQ domains; hospitalization, medical procedures and illness and its consequences (70 children: Analysis 13.1). Lastly Meisel 2009 found children's anxiety (as measured by the Facial Affective Scale (FAS)) not to differ significantly between clown and parental-presence-only groups (61 children; Analysis 13.1). In relation to co-operation, Fernandes 2010 reported children in the clown group to have significantly increased affective valence, but lower arousal (MD 2.08, (95\% CI 1.42 to 2.74; and MD $1.70,95 \%$ CI -2.33 to -1.07 respectively) in 70 children; Analysis 13.2 .

\section{Primary outcomes (compared with sedative premedication):}

Golan 2009 and Vagnoli 2010 also compared clowns/clown doctors with midazolam. They found no significant differences in child anxiety in the operating room (mYPAS MD -9.67, 95\% CI -21.14 to 1.80 , random-effects, $\mathrm{I}^{2}=66 \%$; 2 trials of 93 children; Analysis 14.1). However, at the time of mask application, midazolam was superior to the presence of clowns/clown doctors in reducing child anxiety (mYPAS MD 12.80, 95\% CI 3.65 to 21.95; one trial of 43 children; Analysis 14.1).

\section{Secondary outcomes (compared with parental presence):}

Parental anxiety (measured as STAI (state)) was significantly lower for the clown group compared with parental presence (MD $0.34,95 \%$ CI -0.54 to -0.14 ; two trials; $\mathrm{n}=120$ ) while other measures of parental anxiety did not demonstrate significant differences between groups; Analysis 13.3.

In Meisel 2009, children in the clown group were significantly less likely to demonstrate negative postoperative behaviour than those in the parental-presence-only group (MD PHBQ -6.30, 95\% CI -12.58 to $-0.02 ; \mathrm{n}=61$ ) Analysis 13.4 .

Fernandes 2010 reported that most health professionals supported the presence of clowns, considering them useful for children (96\%), for parents (89\%) and for themselves (64\%).

\author{
Secondary outcomes (compared with sedative \\ premedication):
}

In a single trial of 50 children, parental anxiety was significantly higher in the clowns/clown doctors group than in the midazolam group for STAI (state) but not for STAI (trait): MD 21.12, 95\% CI 13.95 to 28.29 ; and MD $-4.24,95 \%$ CI -13.72 to 5.24 respectively; Analysis 14.2.

\subsubsection{Hypnosis}

\section{Primary outcomes:}

Compared with midazolam premedication, fewer children were anxious (mYPAS > 24) during induction of anaesthesia in the hypnotherapy group in a single trial of 50 children (Calipel 2005), but this did not reach statistical significance (RR 0.59, 95\% CI 0.33 to 1.04 ; Analysis 15.1).

\section{Secondary outcomes:}

Significantly fewer children demonstrated negative behaviour postoperatively in the hypnotherapy group (during day 1; RR $0.48,95 \%$ CI 0.24 to 0.96 , and during day 7 ; RR $0.44,95 \%$ CI 0.21 to 0.94 ) compared with the midazolam group; Analysis 15.2.

\section{Parent interventions to assist induction of general anaesthesia in their child}

Three trials assessed the effect of an intervention for the parent during preoperative preparation (McEwen 2007; Wang 2004; Zuwala 2001).

\section{I Parental acupuncture}

In a trial of 67 children, Wang 2004 compared the effects of anxiety-reduction acupuncture and sham acupuncture administered to parents prior to induction of anaesthesia for their child.

\section{Primary outcomes:}

Children of parents who had acupuncture compared with children whose parents received sham acupuncture were significantly less anxious during induction (mYPAS MD -17, 95\% CI -30.51 to 3.49) Analysis 16.1. In addition, children of the parents undergoing acupuncture were more co-operative: perfect induction (ICC rated 0) RR 1.59, 95\% CI 1.01 to 2.53; Analysis 16.2.

\section{Secondary outcomes:}

Parental anxiety was significantly lower in those who had received anxiety-reduction acupuncture (STAI MD -6.6, 95\% CI -11.64 to -1.56). However there were no significant differences in the parents' physiological variables; heart rate (MD $0.5 \mathrm{bpm}, 95 \% \mathrm{CI}$ -4.77 to 5.77 ); systolic blood pressure (MD $0 \mathrm{mmHg}$, 95\% CI - 
$7.04 \mathrm{mmHg}$ to $7.04 \mathrm{mmHg}$ ); and diastolic blood pressure (MD $0 \mathrm{mmHg}, 95 \% \mathrm{CI}-4.81 \mathrm{mmHg}$ to $4.81 \mathrm{mmHg}$ ) Analysis 16.3.

\subsection{Parental video}

Two trials with 191 parents (McEwen 2007; Zuwala 2001) assessed the effects of parental video viewing on parental and child responses.

\section{Primary outcomes:}

Neither trial reported any of the review's prespecified primary outcomes.

\section{Secondary outcomes:}

In Zuwala 2001, postoperative behavioural scores in the recovery room were significantly lower in children in the group where parents had viewed the video compared with parents who had received an information pamphlet only (P value $=0.013$ ).

Apart from a small but statistically significant reduction in mean arterial blood pressure (MD $-4.00 \mathrm{mmHg}, 95 \% \mathrm{CI}-7.27 \mathrm{mmHg}$ to $-0.73 \mathrm{mmHg}$ ), there were no differences in other parameters (heart rate, parental STAI) in parents who had viewed a twominute video demonstrating a paediatric mask induction in addition to an educational pamphlet (Zuwala 2001) Analysis 17.1.

In McEwen 2007, there were no differences between the video and no-video groups for total parental anxiety (as measured by APAIS score), although the score for the APAIS desire for information component was borderline (MD -0.82 points, $95 \% \mathrm{CI}-1.64$ to 0.00) Analysis 17.1. 


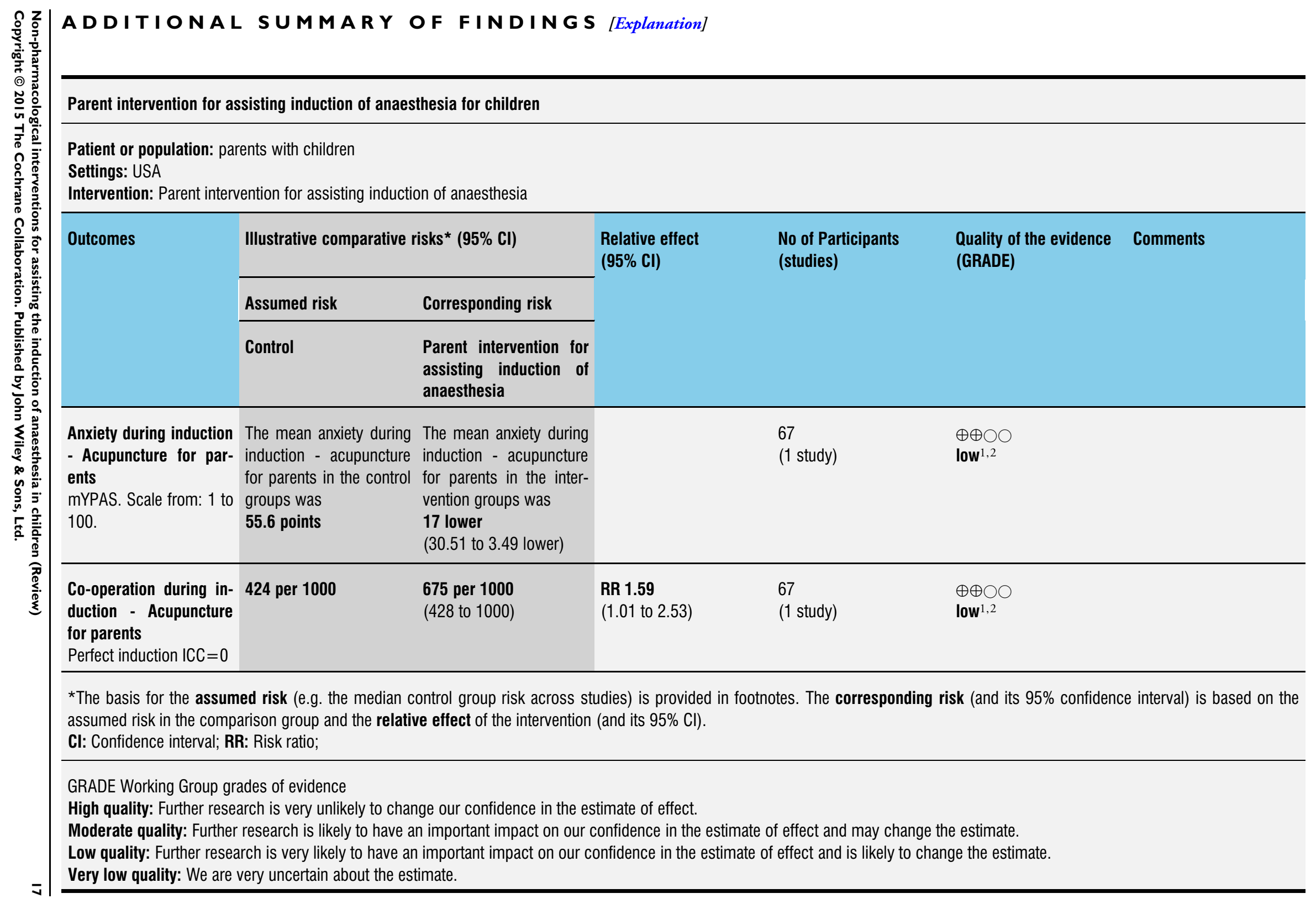




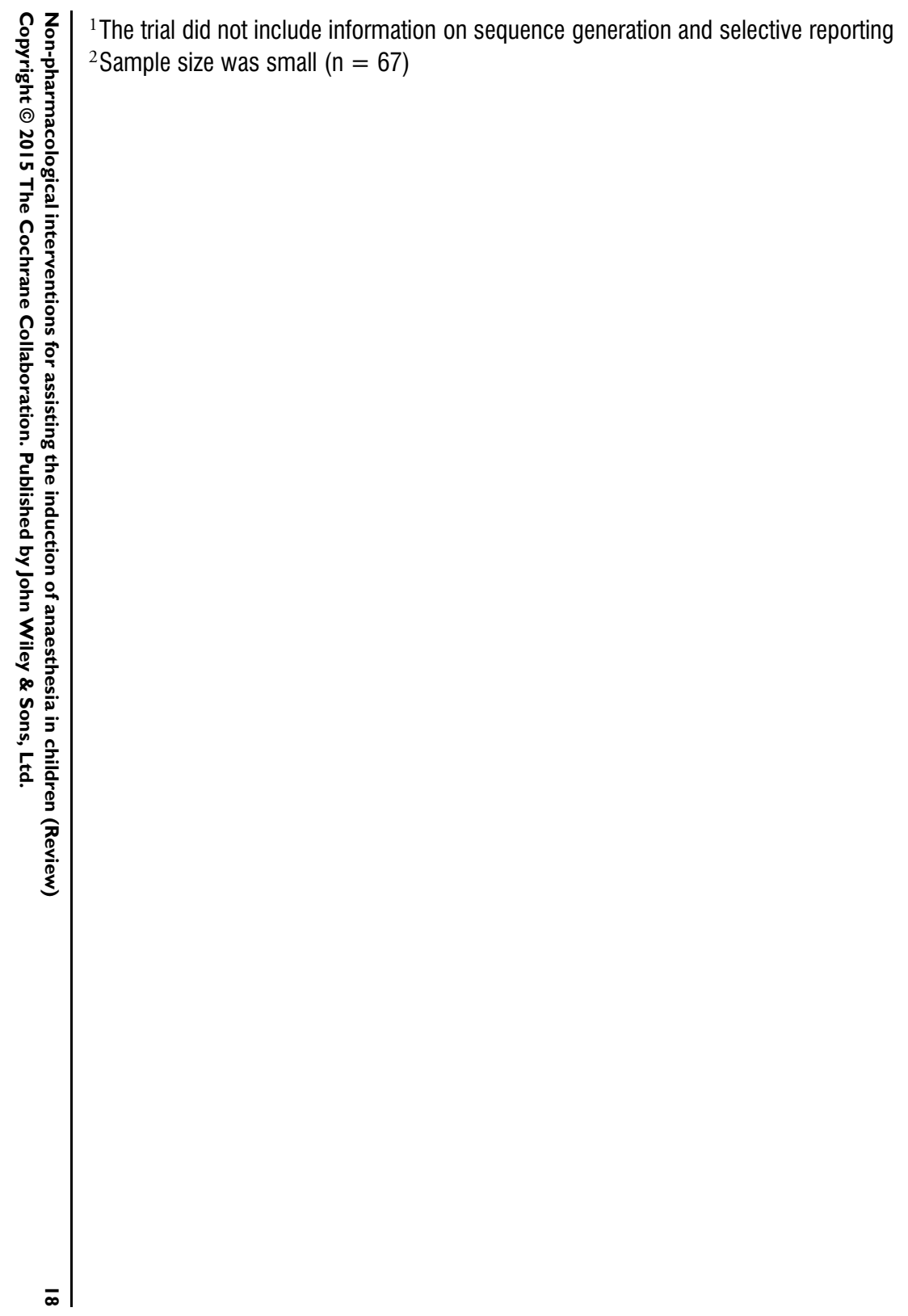




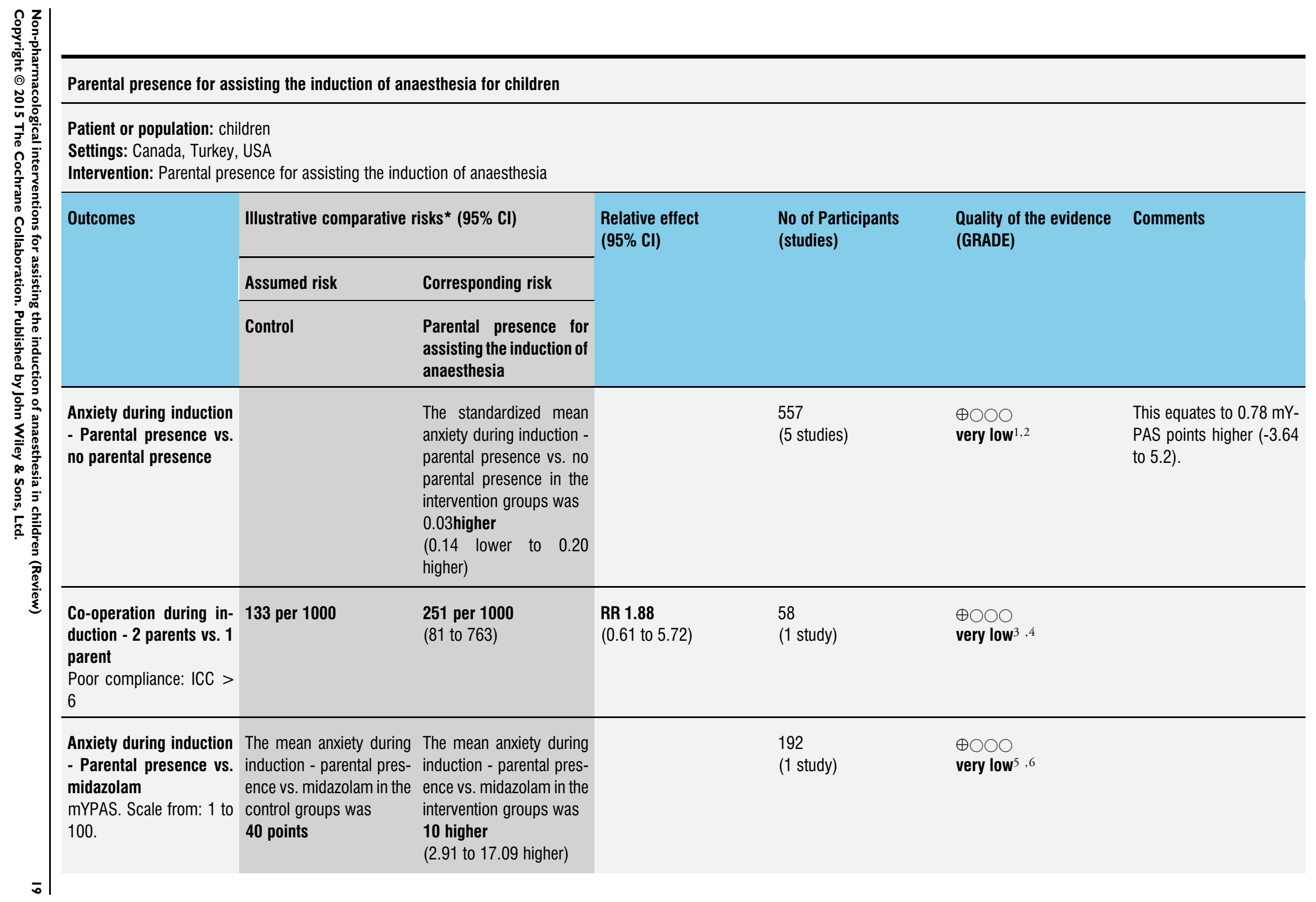




\begin{tabular}{llll}
\hline $\begin{array}{l}\text { Co-operation during in- } \\
\text { duction - Parental pres- } \\
\text { ence vs. midazolam }\end{array}$ & 7 & RR 12.47 & 62 \\
$\begin{array}{l}\text { Poor compliance: ICC }> \\
6\end{array}$ & $(0.72$ to 216.2) & $(1$ study) & \\
\hline
\end{tabular}

*The basis for the assumed risk (e.g. the median control group risk across studies) is provided in footnotes. The corresponding risk (and its $95 \%$ confidence interval) is based on the assumed risk in the comparison group and the relative effect of the intervention (and its $95 \% \mathrm{Cl}$ ).

Cl: Confidence interval; RR: Risk ratio;

GRADE Working Group grades of evidence

High quality: Further research is very unlikely to change our confidence in the estimate of effect.

Moderate quality: Further research is likely to have an important impact on our confidence in the estimate of effect and may change the estimate.

Low quality: Further research is very likely to have an important impact on our confidence in the estimate of effect and is likely to change the estimate.

Very low quality: We are very uncertain about the estimate.

${ }^{1}$ High selection bias, little information on performance, detection and attrition biases

2Kain 2007 only provided information re selection bias; high performance bias in Wright 2010 and information related to selection bias

and reporting bias was missing

3 Information related to selection bias and attrition bias was missing; performance bias was high

${ }^{4}$ The sample size was small $(n=58)$

${ }^{5}$ The paper had little or no information to assess selection, detection, performance, attrition and reporting biases

${ }^{6}$ The sample size was small $(\mathrm{n}=192)$

7 The risk in control was $0 \%$

${ }^{8}$ The paper had insufficient information related to selection, detection, attrition biases and high performance biases

${ }^{9}$ The sample size was small $(\mathrm{n}=62)$ 


\section{DISCUSSION}

\section{Summary of main results}

This updated review has shown that there are several non-pharmacological interventions that are likely to be helpful in reducing children's anxiety and improving their co-operation during induction of anaesthesia. These include parental acupuncture; clown doctors; hypnosis; low sensory stimulation; hand-held video games and behavioural intervention. Interestingly, 'parental presence' at induction of anaesthesia has been the most frequently studied intervention but has not been shown to be useful despite its widespread practice. Most of the outcomes of this review were based on single studies only. However, even single studies can provide useful information of relevance both for clinical practice and, to guide future research.

\section{Quality of the evidence}

We have encountered several difficulties in collating the information from the included studies, as few studies reported dichotomous outcomes of whether or not the child had anxiety, distress, or co-operation (our primary outcome). Although most studies used some sort of scoring system, few used the same measure of anxiety and co-operation. Similarly other outcome measures were rarely consistent across studies. For example, of the 11 studies investigating parental presence, only six measured the outcome 'time during induction' in a way suitable for meta-analysis (Kain 1996b; Kain 1998; Kain 2009; Kazak 2010; MacLaren 2008; Vagnoli 2010). On an individual study basis, we did not find parental presence to be helpful in reducing distress of children in any of the trials, except for one study where a subgroup of 'calm parents' showed reduced anxiety of children at induction (Bevan 1990). Apart from the possibility that parental presence may not be an effective intervention, there are several other likely reasons for this finding. Firstly, a combination of interventions was used in individual trials, especially so for the use of premedications. Secondly, several different measures of anxiety and distress were used, preventing statistical aggregation of the different scoring scales for anxiety. Thirdly, some studies failed to publish numerical results. Lastly, most interventions were visible during induction of anaesthesia in the form of specific personnel or equipment, and the assessment of anxiety was by direct observation. As a result, most participants, anaesthetists and observers could not be blinded to the intervention.

There is some evidence suggesting younger children have greater emotional reactions to preoperative hospitalization than older children. Stratification for age was done in one study (Patel 2006) but the number of children in each group was small and no benefit was demonstrated. Adolescents have not been studied in any of the studies included in this review. Children with chronic illness, especially those with developmental delay, who had previous surgery and hospitalization, were excluded in most studies. It is possible that these children could benefit most from non-pharmacological interventions.

Research into this subject has largely been performed over the last two decades. Observational tools used to assess anxiety have evolved over this time. More recent studies employed the revised versions of these anxiety scales which have been shown to be wellvalidated and reliable (Nilsson 2012). Unfortunately, the trials included in this review used different versions of the scale at different time points, which prevented pooling of results. Even though we included only randomized or quasi-randomized controlled trials, poor methodology and inadequate reporting limited data extraction and our presentation of analyses.

\section{A U THORS'CONCLUSIONS}

\section{Implications for practice}

Parental presence during induction of anaesthesia in children has not been shown to reduce anxiety or improve co-operation of children. Calm parents may be helpful and parental presence should be considered on an individual patient basis. Although parents should not be actively discouraged from being present if they prefer to do so, equally parents should not be encouraged to be present at their child's induction if they prefer not to do so. The use of possibly effective interventions reported in this review, such as parental acupuncture, clown doctors, hypnosis, low sensory stimulation, and hand-held video games, are likely to be helpful in reducing children's anxiety and improving their co-operation during induction of general anaesthesia.

\section{Implications for research}

Although we were able to include another 11 trials and nearly 1000 more participants, these trials are still too small to be adequately powered . Large randomized controlled trials are required, confirming or refuting the usefulness of some of the promising non-pharmacological interventions, such as parental acupuncture; clown doctors; hypnosis; low sensory stimulation; and hand-held video games. Future studies should consider consistency in reporting and the use of validated, reliable methods of assessing anxiety and co-operation in children during induction, preferably using dichotomous outcomes. Future studies should plan for subgroup analyses of different age groups; children with chronic illness, with behavioural problems or development delay. Such trials need to use reliable methods of allocation concealment and to describe these methods in the trial publications.

This review has found possible benefits to the child at induction when parental relaxation was achieved using acupuncture. This 
effect was not seen when parents viewed a video and information pamphlet as preparation for their child's induction. It is interesting that we have found no other studies specifically investigating how relaxation interventions with parents such as hypnosis, meditation, or yoga, might affect outcomes in the child at induction of anaesthesia. This would be an interesting area for future research. Other potential areas for future research that have not been adequately investigated to date include: environmental interventions; equipment modification; number of medical staff in the room; and types of anaesthetist communications used during induction. Standardization of reporting of randomized controlled trials should facilitate meta-analyses of results and increase the likelihood of definitive recommendations regarding the utility of the various non-pharmacological interventions in future.

\section{ACKNOW LEDGEMENTS}

We would like to thank Andrew Smith (content editor), Nathan Pace (statistical editor), Bruce Lindsay, Daniel David, Megan Prictor, William B. McIlvaine (external peer reviewers), Ann Fona and Suzanne Cunliff (Cochrane Consumer Network) for their help and editorial advice during the preparation of this review.

We would like to thank Andrew Smith, John Carlisle, Megan Prictor, William McIlvaine and Janet Wale for their help and editorial advice during the preparation of the protocol for the review.

Alison Carlyle helped screen search results, appraise quality and abstract data in a previous version of this review.

We wish to thank Zohra Lassi for drafting the 'Summary of findings' table.

\section{R E F E R E N C E S}

\section{References to studies included in this review}

Akinci 2008 \{published data only\}

Akinci SB, Kose EA, Ocal T, Aypar U. The effects of maternal presence during anesthesia induction on the mother's anxiety and changes in children's behavior. Turkish Journal of Pediatrics 2008;50(6):566-71.

Arai 2007 \{published data only\}

Arai YC, Ito H, Kandatsu N, Kurokawa S, Kinugasa S, Komatsu T. Parental presence during induction enhances the effect of oral midazolam on emergence behavior of children undergoing general anaesthesia. Acta Anaesthesiologica Scandinavica 2007;51(7):858-61. [PUBMED: 17578463 ]

Berghmans 2012 \{published data only\}

Berghmans J, Weber F, Van Akoleyen C, Utens E, Adriaenssens $\mathrm{P}$, Klein J, et al. Audiovisual aid viewing immediately before pediatric induction moderates the accompanying parents' anxiety. Pediatric Anesthesia 2012; 22(4):386-92. [PUBMED: 22176212]

Bevan 1990 \{published data only\} Bevan JC, Johnston C, Haig MJ, Tousignant G, Lucy S, Kirnon V, et al. Preoperative parental anxiety predicts behavioural and emotional responses to induction of anaesthesia in children. Canadian Journal of Anaesthesia 1990;37(2):177-82. [PUBMED: 2311148]

Calipel 2005 \{published data only\}

Calipel S, Lucas-Polomeni MM, Wodey E, Ecoffey C. Premedication in children: hypnosis versus midazolam. Pediatric Anesthesia 2005;15(4):275-81. [PUBMED: 15787917]

Campbell 2005 \{published data only\} Campell C, Hosey MT, McHugh S. Facilitating coping behavior in children prior to dental general anesthesia: a randomized controlled trial. Pediatric Anesthesia 2005;15 (10):831-8. [PUBMED: 16176310 ]
Fernandes 2010 \{published data only\}

Fernandes SC, Arriaga P. The effects of clown intervention on worries and emotional responses in children undergoing surgery. Journal of Health Psychology 2010;15(3):405-15. [PUBMED: 20348361]

Golan 2009 \{published data only\} Golan G, Tighe P, Dobija N, Perel A, Keidan I. Clowns for the prevention of preoperative anxiety in children: a randomized controlled trial. Pediatric Anesthesia 2009;19 (3):262-6. [PUBMED: 19143948]

Kain 1996b \{published data only\} Kain Z, Mayes L, Caramico L, Silver D, Spieker M, Nygren $\mathrm{M}$, et al. Parental presence during induction of anesthesia: a randomized controlled trial. Anesthesiology 1996;84(5): 1060-7. [PUBMED: 8623999 ]

Kain 1998 \{published data only\} Kain ZN, Mayes LC, Wang SM, Caramico LA, Hofstadter MB. Parental presence during induction of anesthesia versus sedative premedication: which intervention is more effective?. Anesthesiology 1998;89(5):1147-56. [PUBMED: 9822003]

Kain 2000 \{published data only\} Kain ZN, Mayes LC, Wang SM, Caramico LA, Krivutza DM, Hofstadter MB. Parental presence and a sedative premedication for children undergoing surgery. Anesthesiology 2000;92(4):939-46. [PUBMED: 10754612]

Kain 2001 \{published data only\} Kain ZN, Wang SM, Mayes LC, Krivutza DM, Teague BA. Sensory stimuli and anxiety in children undergoing surgery: a randomized, controlled trial. Anesthesia and Analgesia 2001;92(4):897-903. [PUBMED: 11273921]

Kain 2003 \{published data only\} Kain ZN, Caldwell-Andrews AA, Mayes LC, Wang SM, Krivutza DM, LoDolce ME. Parental presence during 
induction of anesthesia. Anesthesiology 2003;98(1):58-64. [PUBMED: 12502980 ]

Kain 2004 \{published data only\}

Kain ZN, Caldwell-Andrews AA, Krivutza DM, Weinberg ME, Gaal D, Wang SM, et al. Interactive music therapy as a treatment for preoperative anxiety in children: a randomized controlled trial. Anesthesia and Analgesia 2004; 98(5):1260-6. [PUBMED: 15105197 ]

Kain 2007 \{published data only\} Kain ZN, Caldwell-Andrews AA, Mayes LC, Weinberg ME, Wang SM, MacLaren JE, et al. Family-centered preparation for surgery improves perioperative outcomes in children: a randomized controlled trial. Anesthesiology 2007;106(1): 65-74. [PUBMED: 17197846 ]

Kain 2009 \{published data only\}

Kain ZN, Maclaren J, Weinberg M, Huszti H, Anderson C, Mayes L. How many parents should we let in the operating room?. Pediatric Anesthesia 2009;19(3):244-2. [PUBMED: 19143951]

Kazak 2010 \{published data only\}

Kazak Z, Sezer GB, Ylmaz AA, Ates Y. Premedication with oral midazolam with or without parental presence. European Journal of Anaesthesiology 2010;27(4):347-2. [PUBMED: 20306569]

MacLaren 2008 \{published data only\}

MacLaren JE, Kain ZN. Development of a brief behavioral intervention for children's anxiety at anesthesia induction. Children's Health Care 2008;37(3):196-209.

McEwen 2007 \{published data only\}

McEwen A, Moorthy C, Quantock C, Rose H, Kavanagh $\mathrm{R}$. The effect of videotaped preoperative information on parental anxiety during anesthesia induction for elective pediatric procedures. Paediatr Anaesth 2007;17(6):534-9. [PUBMED: 17498014]

Meisel 2009 \{published data only\}

Meisel V, Chellew K, Ponsell E, Ferreira A, Bordas L, Garcia-Banda G. The effect of hospital clowns on distress and maladaptive behaviours of children who are undergoing minor surgery [El efecto de los payasos de hospital en el malestar psicologico y las conductas desadaptativas de ninos y ninas sometidos a cirugia menor]. Psicothema 2009;21(4): 604-9. [PUBMED: 19861106]

Mifflin 2012 \{published data only\} Mifflin KA, Hackman T, Chorney J. Streamed video clips to reduce anxiety in children during inhaled induction of anesthesia. Anaesthesia and Analgesia 2012;115(5):1162-7. [PUBMED: 23051880]

Palermo 2000 \{published data only\} Palermo TM, Tripi PA, Burgess E. Parental presence during anaesthesia induction for outpatient surgery of the infant. Paediatric Anaesthesia 2000;10(5):487-91. [PUBMED: 11012951 ]

Patel 2006 \{published data only\}

Patel A, Schieble T, Davidson M, Tran MC, Schoenberg C, Delphin E, et al. Distraction with a hand-held video game reduces pediatric preoperative anxiety. Pediatric Anesthesia 2006;16(10):1019-26. [PUBMED: 16972829]

Vagnoli 2005 \{published data only\}

Vagnoli L, Caprilli S, Robiglio A, Messeri A. Clown doctors as a treatment for preoperative anxiety in children: a randomized, prospective study. Pediatrics 2005;116(4): e563-7. [PUBMED: 16199685]

Vagnoli 2010 \{published data only\}

Vagnoli L, Caprilli S, Messeri A. Parental presence, clowns or sedative premedication to treat preoperative anxiety in children: what could be the most promising option? . Pediatric Anesthesia 2010;20(10):937-3. [PUBMED: 20849499]

Wang 2004 \{published data only\} Wang SM, Maranets I, Weinberg ME, Caldwell-Andrews AA, Kain ZN. Parental auricular acupuncture as an adjunct for parental presence during induction of anesthesia. Anesthesiology 2004;100(6):1399-404. [PUBMED: 15166558 ]

Wright 2010 \{published data only\}

Wright KD, Stewart SH, Allen Finley G. When are parents helpful? A randomised clinical trial of the efficacy of parental presence for paediatric anaesthesia [quand les parents sont-ils utiles? Une etude clinique randomisee sur l'efficacite de la presence parentale lors d'une anesthesie pediatrique]. Canadian Journal of AnesthesialJournal Canadien d'Anesthesie. 2010;57(8):751-8. [PUBMED: 20499223]

Zuwala 2001 \{published data only\}

Zuwala R, Barber KR. Reducing anxiety in parents before and during pediatric anesthesia induction. AANA Journal 2001;69(1):21-5. [PUBMED: 11759134]

\section{References to studies excluded from this review}

Agostini 2014 \{published data only\} Agostini F, Monti F, Neri E, Dellabartola S, De Pascalis L, Bozicevic L. Parental anxiety and stress before pediatric anesthesia: A pilot study on the effectiveness of preoperative clown intervention. Journal of Health Psychology 2014;19 (5):587-601. [DOI: 10.1177/1359105313475900]

Akin 2012 \{published data only\}

Akin A, Bayrum A, Esmaoglu A, Tosun Z, Aksu R, Altuntas $\mathrm{R}$, et al. Dexmedetomidine vs midazolam for premedication of pediatric patients undergoing anesthesia. Pediatric Anesthesia 2012;22(9):871-6.

Aydin 2008 \{published data only\} Aydin T, Sahin L, Algin C, Kabay S, Yucel M, Hacioglu A, et al. Do not mask the mask: use it as a premedicant. Pediatric Anesthesia 2008;18(2):107-12. [PUBMED: 18184240 ]

Cumino 2013 \{published data only\} Cumino Dde O, Cagno G, Gonçalves VF, Wajman DS, Mathias LA. Impact of preanesthetic information of parents and children. Brazilian Journal of Anesthesiology 2013;63 (6):473-82. [DOI: 10.1016/j.bjane.2013.04.003] 
Cuzzocrea 2013 \{published data only\}

Cuzzocrea F, Gugliandolo MC, Larcan R, Romeo C, Turiaco N, Dominici T. A psychological preoperative program: effects on anxiety and cooperative behaviors. Pediatric Anesthesia 2013;23(2):139-43.

Fincher 2012 \{published data only\} Fincher W, Shaw J, Ramelet A S. The effectiveness of a standardised preoperative preparation in reducing child and parent anxiety: a single-blind randomised controlled trial. Journal of Clinical Nursing 2012;21(7-8):946-55.

Fortier 2010 \{published data only\} Fortier MA, Weinberg M, Vitulano LA, Chorney JM, Martin S, Kain ZN. Effects of therapeutic suggestion in children undergoing general anesthesia: a randomized controlled trial.. Pediatric Anesthesia 2010;20(1):90-9. [PUBMED: 20078802]

\section{Gao 2014 \{published data only\}}

Gao XL, Liu Y, Tian S, Zhang DQ, Wu QP. Effect of interesting games on relief of preoperative anxiety in preschool children. International Journal of Nursing Sciences 2014;1(1):89-92. [DOI: 10.1016/j.ijnss.2014.02.002]

Gillerman 1996 \{published data only\} Gillerman RG, Hinkle AJ, Cornell L, Dodge CP. Parental presence plus oral midazolam decreases frequency of $5 \%$ halothane inductions in children. Journal of Clinical Anesthesia 1996;8(6):480-5. [PUBMED: 8872688]

Huet 2011 \{published data only\}

Huet A, Lucas-Polomeni M, Robert J, Sixou J, Wodey E. Hypnosis and dental anesthesia in children: A prospective controlled study. International Journal of Clinical \& Experimental Hypnosis 2011;59(4):424-40.

Kil 2012 \{published data only\} Kil HK, Kim WO, Han SW, Kwon Y, Lee A, Hong JY. Psychological and behavioral effects of chloral hydrate in day-case pediatric surgery: a randomized, observer-blinded study. Journal of Pediatric Surgery 2012;47(8):1592-9.

Kim 2010 \{published data only\} Kim S, Oh Y, Kim K, Kwak YL, Na S. The effect of recorded maternal voice on perioperative anxiety and emergence in children. Anaesthesia and Intensive Care 2010;38(6): 1064-9.

Klemetti 2009 \{published data only\}

Klemetti S, Kinnunem I, Suominen T, Antila H, Vahlberg $\mathrm{T}$, Grenman R, et al. The effect of preoperative nutritional face-to-face counselling about child's fasting on parental knowledge, preoperative need-for-information and anxiety in pediatric ambulatory tonsillectomy.. Patient Education \& Counseling 2010;80(1):64-70.

Lan 2012 \{published data only\}

Lan YP, Huang ZH, Finley GA, Zuo YX. Effects of the combination of mask preconditioning with midazolam pretreatment on anxiety and mask acceptance during pediatric inhalational induction and postoperative mask fear in children. Chinese Medical Journal 2012;125(11): 1908-14.
Lardner 2010 \{published data only\}

Lardner DR, Dick BD, Psych R, Crawford S. The effects of parental presence in postanesthetic care unit on children's postoperative behaviour: A prospective, randomized controlled study. Anesthesia and Analgesia 2010;110(4): 1102-8.

Lee 2012 \{published data only\} Lee J, Lee J, Lim H, Son JS, Lee JR, Kim DC, et al. Cartoon distraction alleviates anxiety in children during induction of anesthesia. Anesthesia \& Analgesia 2012;115(5):1168-73.

\section{Li 2007 \{published data only\}}

Li HC. Evaluating the effectiveness of preoperative interventions: the appropriateness of using the children's emotional manifestation scale. Journal of Clinical Nursing 2007;16(10):1919-26. [PUBMED: 17608635]

* Willaim Li HC, Lopez V, Lee TL. Effects of preoperative therapeutic play on outcomes of school-age children undergoing day surgery. Research in Nursing and Health 2007;30(3):320-32. [PUBMED: 17514706]

Mahajan 2012 \{published data only\} Mahajan RK, Singh I, Kataria AP. Comparison of oral clonidine and midazolam as premedications in children. Journal of Clinical and Diagnostic Research 2012;6(5):870-3.

\section{Markland 1993 \{published data only\}}

Markland D, Hardy L. Anxiety, relaxation and anaesthesia for day-case surgery. British Journal of Clinical Psychology 1993;32(Part 4):493-504. [PUBMED: 8298547 ]

Sadideen 2012 \{published data only\} Sadideen H, Parikh A, Dobbs T, Pay A, Critchley PS. Is there a role for music in reducing anxiety in plastic surgery minor operations?. Annals of the Royal College of Surgeons of England 2012;94(3):152-4.

Schwartz 1983 \{published data only\}

Schwartz BH, Albino JE, Tedesco LA. Effects of psychological preparation on children hospitalized for dental operations. The Journal of Pediatrics 1983;102(4): 634-8. [PUBMED: 6834205 []

Soni 1989 \{published data only\}

Soni JC, Thomas DA. Comparison of anxiety before induction of anaesthesia in the anaesthetic room or operating theatre. Anaesthesia 1989;44(8):651-5. [PUBMED: 2782570 ]

Tripi 2004 \{published data only\}

Tripi PA, Palermo TM, Thomas S, Goldfinger MM, Florentino-Pineda I. Assessment of risk factors for emergence distress and postoperative behavioural changes in children following general anaesthesia. Pediatric Anesthesia 2004;14(3):235-40. [PUBMED: 14996262]

Wang 2005 \{published data only\} Wang SM, Gaal D, Maranets I, Caldwell-Andrews A, Kain $\mathrm{ZN}$. Acupressure and preoperative parental anxiety: a pilot study. Anesthesia and Analgesia 2005;101(3):666-9. [PUBMED: 16115972 ] 
Wang 2008 \{published data only\}

Wang SM, Escalera S, Lin EC, Maranets I, Kain ZN. Extra1 acupressure for children undergoing anesthesia. Anesthesia

\& Analgesia 2008;107(3):811-6. [PUBMED: 18713889]

\section{References to studies awaiting assessment}

\section{Kerimoglu 2013 \{published data only\}}

Kerimoglu B, Neuman A, Paul J, Stefanov DG, Twersky R. Anesthesia induction using video glasses as a distraction tool for the management of preoperative anxiety in children. Anesthesia \& Analgesia 2013;117(6):1373-9. [DOI: 10.1213/ANE.0b013e3182a8c18f]

\section{Additional references}

\section{Aguilera 2003}

Aguilera IM, Patel D, Meakin GH, Masterson J. Perioperative anxiety and postoperative behavioural disturbances in children undergoing intravenous or inhalation induction of anaesthesia. Paediatric Anaesthesia 2003;13(6):501-7. [PUBMED: 12846706 ]

Brady 2009

Brady MC, Kinn S, Ness V, O'Rourke K, Randhawa N, Stuart P. Preoperative fasting for preventing perioperative complications in children. Cochrane Database of Systematic Reviews 2009, Issue 4. [DOI: 10.1002/ 14651858.CD005285.pub2; : ]

\section{Brennan 1994}

Brennan A. Caring for children during procedures: a review of the literature. Pediatric Nursing 1994;20(5):451-8. [PUBMED: 7885763]

Cray 1996

Cray SH, Dixon JL, Heard CM, Selsby DS. Oral midazolam premedication for paediatric day case patients. Paediatric Anaesthesia 1996;6(4):265-70. [PUBMED: 8827741]

Davidson 2006

Davidson AJ, Shrivastava PP, Jamsen K, Huang GH, Czarnecki C, Gibson MA, et al. Risk factors for anxiety at induction of anesthesia in children: a prospective cohort study. Paediatric Anaesthesia 2006;16(9):919-27. [PUBMED: 16918652 ]

\section{Feldman 1998}

Feldman D, Reich N, Foster JM. Pediatric anesthesia and postoperative analgesia. Pediatric Clinics of North America 1998;45(6):1525-37. [PUBMED: 9889765 ]

\section{Greenberg 1996}

Greenberg JA, Davis PJ. Premedication and induction of anesthesia in pediatric surgical patients. Anesthesiology Clinics of North America 1996;14(4):781-2.

\section{Higgins 2002}

Higgins JP, Thompson SG. Quantifying heterogeneity in a meta-analysis. Statistics in Medicine 2002;15(21):1539-58. [PUBMED: 12111919]

\section{Holm-Knudsen 1998}

Holm-Knudsen RJ, Carlin JB, McKenzie IM. Distress at induction of anaesthesia in children. A survey of incidence, associated factors and recovery characteristics. Paediatric Anaesthesia 1998;8(5):383-92. [PUBMED: 9742532]

\section{Iacobucci 2005}

Iacobucci T, Federico B, Pintus C, Francisci G. Evaluation of satisfaction level by parents and children following pediatric anesthesia. Pediatric Anesthesia 2005;15(4): 314-20. [PUBMED: 15787923]

\section{Kain 1996a}

Kain ZN, Mayes LC, O'Connor TZ, Cicchetti DV. Preoperative anxiety in children: predictors and outcomes. Archives of Pediatrics \& Adolescent Medicine 1996;150(12): 1238-45. [PUBMED: 8953995 ]

\section{Kain 1997}

Kain ZN, Mayes LC, Cicchetti DV, Bagnall AL, Finley JD, Hofstadter MB. The Yale Preoperative Anxiety Scale: how does it compare with a "gold standard"?. Anaesthesia and Analgesia 1997;85(4):783-8. [PUBMED: 9322455]

\section{Kain 1999a}

Kain ZN, Mayes LC, Wang SM, Hofstadter MB. Postoperative behavioral outcomes in children effects of sedative premedication. Anesthesiology 1999;90(3):758-65. [PUBMED: 10078677]

Kain 1999b

Kain ZN, Wang SM, Mayes LC, Caramico LA, Hofstadter MB. Distress during the induction of anesthesia and postoperative behavioral outcomes. Anesthesia and Analgesia 1999;88(5):1042-7. [PUBMED: 10320165]

\section{Kain 2005}

Kain ZN, Caldwell-Andrews AA. Preoperative psychological preparation of the child for surgery: an update. Anesthesiology Clinics of North America 2005;23(4): 597-614. [PUBMED: 16310653 ]

\section{Kotiniemi 1997}

Kotiniemi LH, Ryhanen PT, Moilanen IK. Behavioural changes in children following day-case surgery: a 4-week follow-up of 551 children. Anaesthesia 1997;52(10):970-6. [PUBMED: 9370839]

\section{Lee 2003}

Lee A, Chui PT, Gin T. Educating patients about anesthesia: a systematic review of randomized controlled trials of media-based interventions. Anesthesia and Analgesia 2003; 96(5):1424-31. [PUBMED: 12707146]

Lee 2005

Lee A, Gin T. Educating patients about anaesthesia: effect of various modes on patients' knowledge, anxiety and satisfaction. Current Opinion in Anaesthesiology 2005;18(2): 205-8. [PUBMED: 16534340]

\section{Nilsson 2012}

Nilsson S, Buchholz M, Thunberg G. Assessing children's anxiety using the modified Short State-Trait Anxiety Inventory and talking mats: a pilot study. Nursing Research and Practice 2012;2012:1-7. [DOI: 10.1155/2012/ 932570]

\section{Pillai Riddell 2011}

Pillai Riddell RR, Racine NM, Turcotte K, Uman LS, Horton RE, Din Osmun L, et al. Non-pharmacological 
management of infant and young child procedural pain. Cochrane Database of Systematic Reviews 2011, Issue 10. [DOI: 10.1002/14651858.CD006275.pub2]

\section{RevMan 5.3}

The Nordic Cochrane Centre, The Cochrane Collaboration. Review Manager (RevMan) Version 5.3 for Windows. Copenhagen: The Nordic Cochrane Centre, The Cochrane Collaboration, 2014.

\section{Stargatt 2006}

Stargatt R, Davidson AJ, Huang GH, Czarnecki C, Gibson MA, Stewart SA, et al. A cohort study of the incidence and risk factors for negative behavior changes in children after general anesthesia. Pediatric Anesthesia 2006;16(8):846-59. [PUBMED: 16884468 ]

\section{Ullyot 1999}

Ullyot SC. Paediatric premedication. Canadian Journal of Anaesthesia 1999;39(6):533-6.

\section{Uman 2013}

Uman LS, Birnie KA, Noel M, Parker JA, Chambers CT, McGrath PJ, et al. Psychological interventions for needle-related procedural pain and distress in children and adolescents. Cochrane Database of Systematic Reviews 2013, Issue 10. [DOI: 10.1002/14651858.CD005179.pub3]

\section{Van den Berg 2005a}

Van den Berg AA, Chitty DA, Jones RD, Sohel MS, Shahen A. Intravenous or inhaled induction of anesthesia in adults? An audit of preoperative patient preferences. Anesthesia and Analgesia 2005;100(5):1422-4. [PUBMED: 15845699]

\section{Van den Berg 2005b}

Van den Berg AA, Muir J. An audit of pediatric patient choice of route for induction of anesthesia: 19\% choose an intravenous induction! [abstract]. Anesthesiology 2005;103: A1363.

Wollin 2003

Wollin SR, Plummer JL, Owen H, Hawkins RM, Materazzo F. Predictors of preoperative anxiety in children. Anaesthesia and Intensive Care 2003;31(1):69-74. [PUBMED: 12635399]

\section{References to other published versions of this review}

\section{Yip 2009}

Yip P, Middleton P, Cyna AM, Carlyle AV. Nonpharmacological interventions for assisting the induction of anaesthesia in children. Cochrane Database of Systematic Reviews 2009, Issue 3. [DOI: 10.1002/ 14651858.CD006447.pub2]

* Indicates the major publication for the study 


\section{CHARACTERISTICS OF STUDIES}

\section{Characteristics of included studies [ordered by study ID]}

\section{Akinci 2008}

\begin{tabular}{l|l}
\hline Methods & RCT \\
\hline Participants & $\begin{array}{l}100 \text { children ages of } 2 \text { - 10, ASA I - II, elective ambulatory surgery under general } \\
\text { anaesthesia } \\
\text { Exclusions: children with a past history of cardiac, pulmonary, hepatic or renal insuffi- } \\
\text { ciency or who had known psychological problems } \\
\text { Setting: Turkey }\end{array}$ \\
\hline
\end{tabular}

Interventions

\section{PARENTAL PRESENCE:}

1. Parental presence (mother present): $\mathrm{n}=50$

2. No parental presence (mother absent): $n=50$

All had midazolam $0.5 \mathrm{mg} / \mathrm{kg}$ intranasally at least 20 minutes before surgery

All received inhalation induction: oxygen/nitrous oxide/sevoflurane

$\begin{array}{ll}\text { Outcomes } & \text { Preoperatively (on day of surgery): child's behaviour measured by PHBQ } \\ \text { At induction: child's level of stress using 4-point scale (1 = agitated, crying and not co- } \\ \text { operative, } 4 \text { = sleeping) } \\ \text { Preoperatively (on the day of surgery) mother's trait anxiety measured by STAI (Trait) } \\ \text { Preoperatively (on day of surgery): mother's state anxiety measured by STAI (State) } \\ \text { Postoperatively (1 week after surgery): mother's state anxiety measured by STAI (State) }\end{array}$

Notes

The mother completed the PHBQ preoperatively to determine the child's behaviour disturbances

A psychologist assessed and administered the STAI and PHBQ postoperatively

\section{Risk of bias}

\section{Bias}

Authors' judgement Support for judgement

Random sequence generation (selection Low risk Random number table bias)

Allocation concealment (selection bias) Unclear risk $\quad$ Methods of allocation concealment not reported

Blinding of participants and personnel High risk (performance bias)

Not reported but blinding unlikely due to the nature of the

All outcomes interventions

Blinding of outcome assessment (detection Unclear risk "A psychologist functioned as the assessor" bias)

All outcomes

Incomplete outcome data (attrition bias) Low risk No losses reported All outcomes 
Akinci 2008 (Continued)

\begin{tabular}{lll}
\hline Selective reporting (reporting bias) & Unclear risk & Limited number of outcomes reported \\
\hline Other bias & Low risk & No other concerns noted \\
\hline
\end{tabular}

Arai 2007

\begin{tabular}{|c|c|}
\hline Methods & RCT \\
\hline \multirow[t]{5}{*}{ Participants } & 60 children \\
\hline & Inclusion criteria: Children aged 1 - 3 years, ASA I undergoing minor plastic surgery \\
\hline & under GA \\
\hline & $\begin{array}{l}\text { Exclusion: History of chronic illness, prematurity or developmental delay, history of } \\
\text { previous surgery }\end{array}$ \\
\hline & Setting: university hospital, Japan \\
\hline
\end{tabular}

Interventions

\section{PARENTAL PRESENCE}

1. Parental presence (mother) - mother held child throughout induction of anaesthesia $(\mathrm{n}=20)$

2. Parental presence (mother) + midazolam (both as above and below); $\mathrm{n}=19$

3. Sedative (midazolam $0.5 \mathrm{mg} / \mathrm{kg}$ oral 40 minutes before induction) $\mathrm{n}=19$

All participants:

Anaesthesia: induced with $7 \%$ sevoflurane in 100\% oxygen, maintained with sevoflurane $1.5-2.5$ in $60 \%$ oxygen and intravenous fentanyl $4 \mathrm{mcg} / \mathrm{kg}$

Sevoflurane was discontinued at the end of surgery

Outcomes

\section{Emergence behaviour:}

5-point scale:

1. Obtunded with no response to stimuli

2. Asleep but response to movement or stimulation

3. Awake and responsive

4. Inconsolable crying

5. Thrashing behaviour requiring restraint

Quality of mask induction (entered as Co-operation in this review):

3-point scale:

1. Readily accepts mask

2. Minimally resistant

3. Fighting

Notes

\section{Risk of bias}

\begin{tabular}{l|l|l}
\hline Bias & Authors' judgement & Support for judgement \\
\hline $\begin{array}{l}\text { Random sequence generation (selection } \\
\text { bias) }\end{array}$ & Low risk & Computer-generated random numbers \\
\hline $\begin{array}{l}\text { Allocation concealment (selection bias) } \\
\text { Non-pharmacological interventions for assisting the induction of anaesthesia in children (Review) } \\
\text { Copyright } \odot 2015 \text { The Cochrane Collaboration. Published by John Wiley \& Sons, Ltd. }\end{array}$ & Unclear risk & Methods of allocation concealment not reported \\
\hline \begin{tabular}{l} 
Non \\
\hline
\end{tabular}
\end{tabular}




\begin{tabular}{l|l|l}
\hline $\begin{array}{l}\text { Blinding of participants and personnel } \\
\text { (performance bias) } \\
\text { All outcomes }\end{array}$ & High risk & Not reported, but unlikely due to the nature of the intervention \\
\hline $\begin{array}{l}\text { Blinding of outcome assessment (detection } \\
\text { bias) } \\
\text { All outcomes }\end{array}$ & Low risk & Outcome assessment was blinded \\
\hline $\begin{array}{l}\text { Incomplete outcome data (attrition bias) } \\
\text { All outcomes }\end{array}$ & Unclear risk & $\begin{array}{l}2 \text { children refused the whole midazolam dose }(1 \text { in the mida- } \\
\text { zolam-only group and } 1 \text { in the midazolam + parental presence } \\
\text { group) }\end{array}$ \\
\hline $\begin{array}{l}\text { Selective reporting (reporting bias) } \\
\text { Other bias }\end{array}$ & Unclear risk & Child anxiety not reported; no parental outcomes reported \\
\hline
\end{tabular}

\section{Berghmans 2012}

\begin{tabular}{ll}
\hline Methods & RCT \\
\hline Participants & 120 children and their parents (mostly mothers), ages 6 months - 16 years, ASA I or \\
& $\begin{array}{l}\text { II, scheduled for day-care surgery (most frequent procedures were urology (32\%) in the } \\
\text { control group and ears, nose, throat (ENT) (35\%) in the intervention group) } \\
\text { No premedication was administered } \\
\text { Setting: Belgium }\end{array}$ \\
\hline
\end{tabular}

Interventions

Outcomes

Notes

\section{Risk of bias}

\section{Bias}

\section{Authors' judgement Support for judgement}




\section{Berghmans 2012 (Continued)}

\begin{tabular}{|c|c|c|}
\hline $\begin{array}{l}\text { Random sequence generation (selection } \\
\text { bias) }\end{array}$ & Low risk & Computer-generated random sequence \\
\hline Allocation concealment (selection bias) & Unclear risk & $\begin{array}{l}\text { Parents picked a computer-generated randomly numbered en- } \\
\text { velope }\end{array}$ \\
\hline $\begin{array}{l}\text { Blinding of participants and personnel } \\
\text { (performance bias) } \\
\text { All outcomes }\end{array}$ & Unclear risk & Not feasible to blind participants and personnel \\
\hline $\begin{array}{l}\text { Blinding of outcome assessment (detection } \\
\text { bias) } \\
\text { All outcomes }\end{array}$ & Low risk & $\begin{array}{l}\text { Child anxiety was assessed by anaesthetists blinded to group } \\
\text { allocation }\end{array}$ \\
\hline $\begin{array}{l}\text { Incomplete outcome data (attrition bias) } \\
\text { All outcomes }\end{array}$ & Low risk & No losses reported \\
\hline Selective reporting (reporting bias) & Unclear risk & $\begin{array}{l}\text { Most expected outcomes are reported, although child anxiety is } \\
\text { reported as median and } 95 \% \text { CI }\end{array}$ \\
\hline Other bias & Low risk & No other concerns apparent \\
\hline
\end{tabular}

\section{Bevan 1990}

\begin{tabular}{ll}
\hline Methods & Quasi-RCT \\
\hline Participants & $\begin{array}{l}134 \text { children ages } 2 \text { - } 10 \text { years, ASA I - II, who spoke French or English and accompanied } \\
\text { by parents with whom they usually lived } \\
\text { All types of surgery included } \\
\text { Setting: Canada; Day Surgery Centre of Montreal Children's Hospital }\end{array}$ \\
\hline Interventions & PARENTAL PRESENCE \\
& $\begin{array}{l}\text { 1. Parental presence ( } \mathrm{n}=65) \\
\text { 2. No parental presence (n }=65) \\
\text { Method of induction: not stated }\end{array}$ \\
\hline
\end{tabular}

Outcomes

Child behaviour responses as measured by 'Hospital fears inventory' $(1=$ no fear, $5=$ very much) preoperatively and after discharge; Global mood scale ( 1 = playing happily, 7 = screaming) at induction; and behavioural questionnaire 1 week postoperatively (mean for each question). $100 \mathrm{~mm}$ VAS to measure anxiety of children at induction

Parental anxiety was measured using questionnaire and $100 \mathrm{~mm}$ VAS

Notes

Parents were divided into 'anxious' or 'calm' based on a median split of their anxiety scores (median VAS 42) in the waiting room

\section{Risk of bias}


Bevan 1990 (Continued)

\begin{tabular}{|c|c|c|}
\hline $\begin{array}{l}\text { Random sequence generation (selection } \\
\text { bias) }\end{array}$ & High risk & Allocation was by day of the week \\
\hline Allocation concealment (selection bias) & High risk & Allocation was by day of the week \\
\hline $\begin{array}{l}\text { Blinding of participants and personnel } \\
\text { (performance bias) } \\
\text { All outcomes }\end{array}$ & Unclear risk & States parents and child were blinded, although this not likely \\
\hline $\begin{array}{l}\text { Blinding of outcome assessment (detection } \\
\text { bias) } \\
\text { All outcomes }\end{array}$ & Unclear risk & Nurse observers could not be blinded. \\
\hline $\begin{array}{l}\text { Incomplete outcome data (attrition bias) } \\
\text { All outcomes }\end{array}$ & Unclear risk & $\begin{array}{l}2 \text { children allocated had parental presence despite allocation to } \\
\text { control and excluded from analysis. Variable dropouts of be- } \\
\text { tween } 1 \text { and } 7 \text { participants with responses to the different mea- } \\
\text { sures }\end{array}$ \\
\hline Selective reporting (reporting bias) & Low risk & Most expected outcomes were reported \\
\hline Other bias & Unclear risk & $\begin{array}{l}\text { No explanation why only } 112 \text { of the } 130 \text { parents were classified } \\
\text { as anxious or calm }\end{array}$ \\
\hline
\end{tabular}

\section{Calipel 2005}

\begin{tabular}{ll}
\hline Methods & RCT \\
\hline Participants & 50 children ages $2-11$. ASA I - II, ambulatory, lower abdominal surgery \\
& Exclusions: Hospitalization in last 6 months; emergency surgery; psychological retarda- \\
& tion \\
& Setting: France \\
\hline
\end{tabular}

Interventions

\section{CHILD/PARENT INTERVENTION: HYPNOSIS}

1. Hypnosis: $\mathrm{n}=23$ (participants allocated to hypnosis received placebo premed plus hypnotic interaction with anaesthetist for 30 minutes prior to induction)

2. Midazolam: $\mathrm{n}=27$ (midazolam participants received midazolam $0.5 \mathrm{mg} / \mathrm{kg} 30$ minutes before surgery and nurse to take patient to theatre).

Inhalational induction with oxygen/nitrous oxide/sevoflurane

Outcomes

mYPAS (0 -100 scale, higher score = greater anxiety) on arrival; entrance to operating room; and on applying facemask; mYPAS > 24 classified as anxious

Hospitalization behavioural questionnaire measured Day 1 and 7 postoperatively

Postoperative pain in recovery measured by objective pain score at $1,30,60,120$ minutes

Notes

Some children had parental presence which was not controlled for

\section{Risk of bias}


Calipel 2005 (Continued)

\begin{tabular}{|c|c|c|}
\hline Bias & Authors' judgement & Support for judgement \\
\hline $\begin{array}{l}\text { Random sequence generation (selection } \\
\text { bias) }\end{array}$ & Unclear risk & "Two randomized groups" \\
\hline Allocation concealment (selection bias) & Unclear risk & "Two randomized groups"; no further details reported \\
\hline $\begin{array}{l}\text { Blinding of participants and personnel } \\
\text { (performance bias) } \\
\text { All outcomes }\end{array}$ & Unclear risk & $\begin{array}{l}\text { Parent and participant blinded but probably partially at best as } \\
\text { children in the hypnosis group talked with the anaesthetist while } \\
\text { s/he established a "hypnotic relation"; not clear if nurse observer } \\
\text { blinded }\end{array}$ \\
\hline $\begin{array}{l}\text { Blinding of outcome assessment (detection } \\
\text { bias) } \\
\text { All outcomes }\end{array}$ & Unclear risk & Not reported \\
\hline $\begin{array}{l}\text { Incomplete outcome data (attrition bias) } \\
\text { All outcomes }\end{array}$ & Low risk & No losses reported \\
\hline Selective reporting (reporting bias) & Unclear risk & Not all expected outcomes were reported or reported fully \\
\hline Other bias & Low risk & No apparent sources of other bias \\
\hline
\end{tabular}

\section{Campbell 2005}

\begin{tabular}{l|l}
\hline Methods & RCT \\
\hline Participants & $\begin{array}{l}198 \text { children aged } 3-10 \text {, for dental extractions under general anaesthesia. No previous } \\
\text { experience of either medical or dental general anaesthesia. English as first language } \\
\text { Setting: dental general anaesthesia service, Scotland }\end{array}$ \\
\hline Interventions & CHILD/PARENT INTERVENTION: COMPUTER/CARTOON \\
1. Interactive computer package preparation (n $=55)$ & $\begin{array}{l}\text { 2. Paper-based cartoon preparation }(\mathrm{n}=55) \\
\text { 3. Control (verbal preparation) }(\mathrm{n}=58) \\
\text { Majority of children had inhalational sevoflurane induction. If specifically requested, an } \\
\text { intravenous induction was used. All had parental presence }\end{array}$
\end{tabular}

Outcomes

Coping VAS $(0$ - 10) at induction and recovery (measuring co-operation and negative behaviour); all reported as medians and ranges

Notes

Risk of bias

Bias

Authors' judgement Support for judgement

Non-pharmacological interventions for assisting the induction of anaesthesia in children (Review) 


\section{Campbell 2005 (Continued)}

\begin{tabular}{l|l|l}
$\begin{array}{l}\text { Random sequence generation (selection } \\
\text { bias) }\end{array}$ & Low risk & Computerized randomization grid \\
\hline Allocation concealment (selection bias) & Unclear risk & Method of allocation concealment not reported \\
\hline
\end{tabular}

\begin{tabular}{|c|c|c|}
\hline $\begin{array}{l}\text { Blinding of participants and personnel } \\
\text { (performance bias) } \\
\text { All outcomes }\end{array}$ & High risk & Not feasible to blind the intervention \\
\hline $\begin{array}{l}\text { Blinding of outcome assessment (detection } \\
\text { bias) } \\
\text { All outcomes }\end{array}$ & Low risk & Outcome assessors were blinded \\
\hline $\begin{array}{l}\text { Incomplete outcome data (attrition bias) } \\
\text { All outcomes }\end{array}$ & Unclear risk & $\begin{array}{l}30 / 198(15 \%) \text { children not assessed for coping behaviour at } \\
\text { induction and } 32 / 198 \text { not assessed at recovery (losses by group } \\
\text { not reported) }\end{array}$ \\
\hline Selective reporting (reporting bias) & Unclear risk & No parental outcomes reported \\
\hline Other bias & Low risk & No other risk of bias apparent \\
\hline
\end{tabular}

Fernandes 2010

\begin{tabular}{ll}
\hline Methods & QuasiRCT \\
\hline Participants & 70 children ( 53 boys) aged $5-12$, scheduled for minor surgery (such as circumcision, \\
herniorrhaphy, excision, orchiopexy and cystoscopy) \\
Inclusion criteria: undergoing minor surgery, accompanied by a family member(mother \\
or father or both), between 5 and 12 years of age and having parental consent to partic- \\
ipate \\
$\begin{array}{l}\text { Exclusions: children under the age of } 5, \text { a history of neurological or psychopathology } \\
\text { disorder as reported by their parents } \\
\text { Setting: Portugal }\end{array}$ \\
\hline
\end{tabular}

Interventions

\section{CLOWNS/CLOWN DOCTORS}

1. Clowns and parents group $(n=35)$ : a pair of clowns (male and female) and parents arrived with the child in the ambulatory room 30 minutes before surgery; the clowns entertained the child for 15 minutes with magic tricks, music, jokes, games and humour

2. Parents-only group: $\mathrm{n}=35$

All participants: Method of induction not stated

Outcomes

Child's temperament: was assessed by their parents through completion of the EAS Temperament Survey for Children

Child's preoperative worries about surgery: was assessed using the CSWQ; 23 items, 5-point scale

Emotional responses: The SAM scale was used to measure the dimensions of valence and arousal 
Fernandes 2010 (Continued)

Parents' preoperative state of anxiety: STAI

Health professionals' opinion regarding presence of clowns: The questionnaire to ascertain the effectiveness of clowns was based on Vagnoli 2005

Notes

Risk of bias

\begin{tabular}{|c|c|c|}
\hline Bias & Authors' judgement & Support for judgement \\
\hline $\begin{array}{l}\text { Random sequence generation (selection } \\
\text { bias) }\end{array}$ & High risk & By day of week \\
\hline Allocation concealment (selection bias) & High risk & $\begin{array}{l}\text { The } 2 \text { groups were scheduled for different days in order to avoid } \\
\text { the awareness of the comparison group about the presence of } \\
\text { clowns with children in the treatment group }\end{array}$ \\
\hline $\begin{array}{l}\text { Blinding of participants and personnel } \\
\text { (performance bias) } \\
\text { All outcomes }\end{array}$ & High risk & Not possible to blind this intervention \\
\hline $\begin{array}{l}\text { Blinding of outcome assessment (detection } \\
\text { bias) } \\
\text { All outcomes }\end{array}$ & High risk & Assessors were not blind to the presence or absence of the clowns \\
\hline $\begin{array}{l}\text { Incomplete outcome data (attrition bias) } \\
\text { All outcomes }\end{array}$ & Low risk & No losses reported \\
\hline Selective reporting (reporting bias) & Low risk & Most expected outcomes were reported \\
\hline Other bias & Low risk & No other concerns \\
\hline
\end{tabular}

Golan 2009

\begin{tabular}{ll}
\hline Methods & RCT \\
\hline Participants & 65 children aged $3-8$ years, ASA I - II scheduled to undergo general anaesthesia and \\
& elective outpatient surgery \\
& Exclusions: a history of previous anaesthesia or chronic illness, preterm birth, develop- \\
& mental delay, or significant hearing or visual impairments \\
& Setting: USA
\end{tabular}

Interventions

\section{CHILD/PARENT INTERVENTIONS: CLOWN DOCTORS/CLOWNS}

1. Clowns $(n=21)$ : children had two specially trained female clowns present upon arrival to the preoperative holding area and throughout OR entrance and mask application for inhalation induction of anaesthesia

2. Midazolam $(\mathrm{n}=22)$ : children received $0.5 \mathrm{mg} / \mathrm{kg}$ oral midazolam 30 minutes before surgery up to a maximum of $15 \mathrm{mg}$

3. Control $(n=22)$ : children did not receive midazolam or clown presence 
Golan 2009 (Continued)

All participants: Method of induction not stated; parents present

Outcomes

Preoperative child anxiety at the entrance to operating room (OR): mYPAS

Preoperative child anxiety during application of mask: mYPAS

Notes

Risk of bias

Bias

Authors' judgement Support for judgement

Random sequence generation (selection Low risk bias)

\begin{tabular}{l|l|l}
\hline Allocation concealment (selection bias) & Unclear risk & No details of method of allocation concealment reported \\
\hline $\begin{array}{l}\text { Blinding of participants and personnel } \\
\text { (performance bias) } \\
\text { All outcomes }\end{array}$ & High risk & Not feasible to blind the intervention \\
\hline $\begin{array}{l}\text { Blinding of outcome assessment (detection } \\
\text { bias) } \\
\text { All outcomes }\end{array}$ & Low risk & $\begin{array}{l}\text { Evaluators were blinded (although clowns may have been visible } \\
\text { in some videos) }\end{array}$ \\
\hline $\begin{array}{l}\text { Incomplete outcome data (attrition bias) } \\
\text { All outcomes }\end{array}$ & Low risk & No losses reported \\
\hline $\begin{array}{l}\text { Selective reporting (reporting bias) } \\
\text { Other bias }\end{array}$ & Unclear risk & Only 1 outcome reported (child anxiety) \\
\hline
\end{tabular}

Kain 1996b

\begin{tabular}{ll}
\hline Methods & RCT \\
\hline Participants & 84 children ages 1 - 6, ASA I - II, elective outpatient surgery under general anaesthesia \\
& Exclusion: previous surgery, hospitalization, chronic illness, developmental delay \\
& Setting: Children's Hospital at Yale-New Haven, USA \\
\hline
\end{tabular}

Interventions

\section{PARENTAL PRESENCE}

1. Parental presence $(n=43)$

2. No parental presence $(n=41)$

All inductions were in the morning with parents dressed in own clothing, using oxygen/ nitrous oxide/halothane in induction room

Outcomes

At induction: child anxiety (YPAS, CARS : $0=$ relaxed, $5=$ loud cry and out of contact with reality) and co-operation (VAS), serum cortisol sampled immediately after intravenous cannula insertion

Parental anxiety was measured by STAI, blood pressure, heart rate. Anaesthetist's blood 
Kain 1996b (Continued)

pressure, heart rate and rated own situational anxiety (STAI 20 - 80 with higher scores denoting higher levels of anxiety) and completed questionnaire rating helpfulness of parents

Duration of induction time

Nausea and vomiting and other anaesthetic complications

Time to discharge

Parents rated own helpfulness to their child and satisfaction with medical staff using $100 \mathrm{~mm}$ VAS

Post-hospital behavioural questionnaire completed by parents at 2 weeks and 6 months

Notes

All participated in a behavioural preoperative preparation programme (consists of providing information to the child and parent, an orientation tour of the operating room and post-anaesthesia care unit and modelling using dolls by child-life specialists related to the specific surgery planned for the child)

\section{Risk of bias}

Bias

Authors' judgement Support for judgement

Random sequence generation (selection Low risk bias)

Allocation concealment (selection bias) Unclear risk Method of allocation concealment not reported

Blinding of participants and personnel Unclear risk (performance bias)

Observers and patients could not be blinded because of the nature of intervention

All outcomes

Blinding of outcome assessment (detection Low risk bias)

Anxiety of both children and parents was rated by indepen-

All outcomes dent "blinded" observers using VAS preoperatively; all inductions were videotaped and analysed

Incomplete outcome data (attrition bias) Unclear risk

6 failed to complete post-hospital behavioural questionnaire at All outcomes 2 weeks. 22 failed to complete questionnaire at 6 months

Selective reporting (reporting bias)

Low risk

Comprehensive range of outcomes reported

Other bias

Low risk

No apparent evidence of other sources of bias

Kain 1998

\begin{tabular}{ll}
\hline Methods & RCT \\
\hline Participants & 93 children ages $2-8$, ASA I - II, elective outpatient surgery under general anaesthesia \\
& $\begin{array}{l}\text { Exclusion: history of chronic illness, prematurity, developmental delay, parents who } \\
\text { insisted on a particular study group } \\
\text { Setting: USA }\end{array}$
\end{tabular}


Kain 1998 (Continued)

\begin{tabular}{|c|c|}
\hline Interventions & $\begin{array}{l}\text { PARENTAL PRESENCE } \\
\text { 1. Parental presence }(\mathrm{n}=29) \\
\text { 2. Midazolam }(0.5 \mathrm{mg} / \mathrm{kg} \text { orally mixed with } 10 \mathrm{mg} / \mathrm{kg} \text { acetaminophen syrup at least } \\
30 \text { minutes before procedure }(\mathrm{n}=33) \\
\text { 3. Control - no parental presence; no medication }(\mathrm{n}=26) \\
\text { All had inhalational gaseous induction with oxygen/nitrous oxide/halothane }\end{array}$ \\
\hline Outcomes & $\begin{array}{l}\text { Child anxiety measured by YPAS and PBRS: } 0=\text { behaviour did not occur, } 3=\text { behaviour } \\
\text { was extreme or lasted a specific amount of time) } \\
\text { Co-operation of children at induction was rated using ICC ( } 1=\text { compliant, > } 1 \text { = non- } \\
\text { compliant) } \\
\text { Parental anxiety measured by STAI } \\
\text { Post-hospital behavioural questionnaire at } 2 \text { weeks post-operative (incidence of neg- } \\
\text { ative behaviour) } \\
\text { Excitement scale was used to rate postoperative excitement } \\
\text { Parental satisfaction with nursing, anaesthesia, overall medical care and overall function } \\
\text { of the surgical centre was measured by Likert scale (poor = } 0 \text {, very good = } 4 \text { ) } \\
\text { Adverse effects, analgesic requirements, pain scores (Children's Hospital of Eastern } \\
\text { Ontario Pain Scale), time to first void, amount of fluid intake } \\
\text { Time to discharge from the PACU and time to 'postoperative recovery' (assessed by } \\
\text { SPRS) }\end{array}$ \\
\hline Notes & 48 children participated in behavioural preoperative preparation program \\
\hline
\end{tabular}

Risk of bias

Bias

Authors' judgement Support for judgement

Random sequence generation (selection Unclear risk Random number table bias)

Allocation concealment (selection bias) Unclear risk "Managing anaesthesiologist, parents, and assessor did not know the randomization code"

Blinding of participants and personnel High risk Not feasible to blind this intervention (performance bias)

All outcomes

Blinding of outcome assessment (detection Unclear risk bias)

All outcomes

Assessors were blinded in the midazolam vs control group but not to the parental-presence group; research nurse who carried out phone interviews to complete post-hospitalization behaviour questionnaire was blinded

Incomplete outcome data (attrition bias) Unclear risk No losses to follow-up but 5 children were excluded post-ranAll outcomes domization because of violation of anaesthetic protocol (sevoflurane instead of halothane); not reported which groups these exclusions were from 
Kain 1998 (Continued)

\begin{tabular}{l|ll}
\hline Selective reporting (reporting bias) & Low risk & Most expected outcomes were reported \\
\hline Other bias & Unclear risk & No apparent evidence of other sources of bias \\
\hline
\end{tabular}

Kain 2000

\begin{tabular}{l|l}
\hline Methods & RCT \\
\hline Participants & $\begin{array}{l}103 \text { children ages } 2-8 \text {, ASA I - II, outpatient surgery under general anaesthesia } \\
\text { Exclusions: history of chronic illness, prematurity, developmental delay } \\
\text { Setting: USA }\end{array}$ \\
\hline
\end{tabular}

Interventions

PARENTAL PRESENCE

1. Parental presence and oral midazolam $(0.5 \mathrm{mg} / \mathrm{kg}): \mathrm{n}$ not clear

2. Oral midazolam $(0.5 \mathrm{mg} / \mathrm{kg})$ without parental presence: $\mathrm{n}$ not clear

All received inhalational induction with oxygen/nitrous oxide/sevoflurane

\begin{tabular}{|c|c|}
\hline Outcomes & $\begin{array}{l}\text { Child anxiety measured by mYPAS. } \\
\text { ICC was used to assess co-operation of children at induction } \\
\text { Parental anxiety was measured using STAI } \\
\text { Satisfaction questionnaire completed by parents } 2 \text { weeks postoperatively } \\
\text { Postoperative excitement scale was used to measure behavioural changes in recovery } \\
\text { Anaesthetic complications were recorded }\end{array}$ \\
\hline Notes & $\begin{array}{l}\text { Some participated in preoperative preparation programme voluntarily } \\
\text { Insufficient reporting (e.g. numbers of children in each group not reported) limited the } \\
\text { ability to meta-analyse the results from this trial }\end{array}$ \\
\hline
\end{tabular}

\section{Risk of bias}

\section{Bias}

Random sequence generation (selection Low risk bias)

Allocation concealment (selection bias) Unclear risk

Blinding of participants and personnel High risk (performance bias)

All outcomes

\section{Authors' judgement Support for judgement}

Random numbers table

Yoked design based on surgical histories; the 1st child undergoing surgery who had not undergone surgery before was randomized to 1 of the 2 groups. The 2 nd child undergoing surgery with no surgical history was allocated automatically to the other group. This ensured almost equal distribution of surgical experience in the 2 groups

Not reported but unlikely due to the nature of the intervention 
Kain 2000 (Continued)

\begin{tabular}{|c|c|c|}
\hline $\begin{array}{l}\text { Blinding of outcome assessment (detection } \\
\text { bias) } \\
\text { All outcomes }\end{array}$ & Unclear risk & Not reported \\
\hline $\begin{array}{l}\text { Incomplete outcome data (attrition bias) } \\
\text { All outcomes }\end{array}$ & Unclear risk & $\begin{array}{l}8 \text { losses to follow-up (groups not reported): } 5 \text { children were ex- } \\
\text { cluded due to protocol violations (e.g. refusal to swallow the } \\
\text { sedative premedication); } 3 \text { families refused to participate "after } \\
\text { notification that they had been randomized to undergo the op- } \\
\text { eration"; } 68 \% \text { response rate to the parent satisfaction question- } \\
\text { naire }\end{array}$ \\
\hline Selective reporting (reporting bias) & Low risk & Most expected outcomes were reported \\
\hline Other bias & Low risk & $\begin{array}{l}\text { No apparent evidence of other sources of bias (apart from some } \\
\text { incomplete reporting as mentioned above) }\end{array}$ \\
\hline
\end{tabular}

Kain 2001

\begin{tabular}{ll}
\hline Methods & RCT \\
\hline Participants & $\begin{array}{l}70 \text { children, ages } 2-7, \text { ASA I - II } \\
\text { Exclusions: any history of chronic illness, prematurity, or developmental delay } \\
\text { Setting: USA }\end{array}$ \\
\hline
\end{tabular}

Interventions

CHILD/PARENT INTERVENTION: LOW SENSORY STIMULATION

1. Low sensory stimulation group (LSSG) - low light, background music (lights dimmed at 200LX, Bach's 'Air on a G string' was played using a CD player set at the 50-60 dB located at a set distance from the child): $n=33$

2. Control: $\mathrm{n}=37$

All received inhalational induction: oxygen/nitrous oxide/sevoflurane

Outcomes

mYPAS was used to rate anxiety of children

Induction co-operation was measured using the ICC

Parental anxiety was measured by STAI

Post-hospitalization behavioural questionnaire was completed by parents at day 1,2 ,

$3,7 \& 14$ postoperatively

Other outcomes: adverse effects, time to discharge, analgesia requirement

Notes

Parental presence was used as rescue therapy on separation to the theatre 11 times ( 5 in the LSSG and 6 control group)

\section{Risk of bias}

Bias

Random sequence generation (selection Low risk bias)

\section{Authors' judgement Support for judgement}

Computer-generated list created from a random-number table 


\section{Kain 2001 (Continued)}

\begin{tabular}{|c|c|c|}
\hline Allocation concealment (selection bias) & Unclear risk & $\begin{array}{l}\text { "Randomized" - yoked design based on child's age type of } \\
\text { surgery, and participation in the preoperative preparation pro- } \\
\text { gramme }\end{array}$ \\
\hline $\begin{array}{l}\text { Blinding of participants and personnel } \\
\text { (performance bias) } \\
\text { All outcomes }\end{array}$ & High risk & Not reported but unlikely due to the nature of the intervention \\
\hline $\begin{array}{l}\text { Blinding of outcome assessment (detection } \\
\text { bias) } \\
\text { All outcomes }\end{array}$ & Unclear risk & Not reported \\
\hline $\begin{array}{l}\text { Incomplete outcome data (attrition bias) } \\
\text { All outcomes }\end{array}$ & Low risk & No losses reported \\
\hline Selective reporting (reporting bias) & Unclear risk & $\begin{array}{l}\text { Most expected outcomes were reported although actual numer- } \\
\text { ical results were not always reported }\end{array}$ \\
\hline Other bias & Unclear risk & No apparent evidence of other sources of bias \\
\hline
\end{tabular}

Kain 2003

\begin{tabular}{ll}
\hline Methods & RCT \\
\hline Participants & 80 children, ASA I - II, elective outpatient surgery \\
& Children had a mean age of about 5 years \\
& Exclusion: history of chronic illness, prematurity, developmental delay \\
& Setting: USA \\
\hline
\end{tabular}

Interventions

\section{PARENTAL PRESENCE}

1. Parental presence $(n=29)$

2. Parental presence and oral midazolam $0.5 \mathrm{mg} / \mathrm{kg} 30$ minutes prior $(\mathrm{n}=27)$

3. Control $(n=24)$

All had inhalational induction using oxygen/nitrous oxide/sevoflurane

Outcomes mYPAS was used to rate anxiety of children

Parental anxiety was measured by STAI, changes in heart rate, skin conductance and blood pressure

Notes

Some participated in behavioural preoperative preparation programmes voluntarily

\section{Risk of bias}

\section{Bias}

Random sequence generation (selection Low risk bias)

\section{Authors' judgement Support for judgement}

"Based on a random number table, parents were assigned to one of the following three experimental groups..." 
Kain 2003

(Continued)

\begin{tabular}{l|l|l}
\hline Allocation concealment (selection bias) & Unclear risk & See above \\
\hline $\begin{array}{l}\text { Blinding of participants and personnel } \\
\text { (performance bias) } \\
\text { All outcomes }\end{array}$ & High risk & Not feasible to blind participants and personnel \\
\hline $\begin{array}{l}\text { Blinding of outcome assessment (detection } \\
\text { bias) } \\
\text { All outcomes }\end{array}$ & Unclear risk & $\begin{array}{l}\text { Not reported, but objective data from Biolog were used to mea- } \\
\text { sure physiological variables }\end{array}$ \\
\hline $\begin{array}{l}\text { Incomplete outcome data (attrition bias) } \\
\text { All outcomes }\end{array}$ & Low risk & No losses reported \\
\hline Selective reporting (reporting bias) & Unclear risk & $\begin{array}{l}\text { Only anxiety (child and parent) reported, with child anxiety } \\
\text { reported only as no significant difference between groups }\end{array}$ \\
\hline Other bias & Low risk & $\begin{array}{l}\text { Parental presence was used a rescue in 1 child in the control } \\
\text { group; no apparent source of other bias }\end{array}$ \\
\hline
\end{tabular}

Kain 2004

\begin{tabular}{ll}
\hline Methods & RCT \\
\hline Participants & 123 children ages 3 - 7, ASA I - II \\
& $\begin{array}{l}\text { Exclusions: history of chronic illness, prematurity, developmental delay, significant hear- } \\
\text { ing or visual impairment } \\
\text { Setting: USA }\end{array}$ \\
\hline
\end{tabular}

Interventions

\section{CHILD/PARENT INTERVENTION: MUSIC THERAPY}

1. Music therapy $(n=51): 20$ mins duration from holding area to completion of induction of anaesthesia

2. Midazolam (oral $0.5 \mathrm{mg} / \mathrm{kg} 20$ - 30 minutes prior) $(\mathrm{n}=34)$

3. Control $(\mathrm{n}=38)$

No parental presence

All children had inhalational induction with oxygen/nitrous oxide/sevoflurane

Outcomes $\quad$ mYPAS was used to rate anxiety of children

Induction co-operation was measured using the ICC

Parental anxiety was measured using STAI

However all outcomes were presented graphically and therefore could not be metaanalysed

\section{Notes}

Some participated in behavioural preoperative preparation programme voluntarily

\section{Risk of bias}

\section{Bias}

Authors' judgement Support for judgement 
Kain 2004 (Continued)

\begin{tabular}{|c|c|c|}
\hline $\begin{array}{l}\text { Random sequence generation (selection } \\
\text { bias) }\end{array}$ & Unclear risk & Not reported \\
\hline Allocation concealment (selection bias) & Unclear risk & $\begin{array}{l}\text { Permuted block randomization in a 1:1:1.5 ratio; more children } \\
\text { were randomized to the music therapy group to ensure an ade- } \\
\text { quate number of cases for each of the } 2 \text { music therapists; method } \\
\text { of allocation concealment not reported }\end{array}$ \\
\hline $\begin{array}{l}\text { Blinding of participants and personnel } \\
\text { (performance bias) } \\
\text { All outcomes }\end{array}$ & High risk & Not reported but unlikely due to the nature of the intervention \\
\hline $\begin{array}{l}\text { Blinding of outcome assessment (detection } \\
\text { bias) } \\
\text { All outcomes }\end{array}$ & Low risk & $\begin{array}{l}\text { Assessors of videotapes of induction were blinded to the purpose } \\
\text { of the study but music therapist was occasionally visible in the } \\
\text { videotapes }\end{array}$ \\
\hline $\begin{array}{l}\text { Incomplete outcome data (attrition bias) } \\
\text { All outcomes }\end{array}$ & Low risk & No losses reported \\
\hline Selective reporting (reporting bias) & Unclear risk & Most expected outcomes were reported but only graphically \\
\hline Other bias & Low risk & No apparent evidence of other sources of bias \\
\hline
\end{tabular}

Kain 2007

\begin{tabular}{ll}
\hline Methods & RCT \\
\hline Participants & 308 children ages $2-10$, ASA I - II elective outpatient surgery under GA \\
& Exclusion: children with a history of chronic illness, prematurity $(<36$ weeks), diagnosed \\
& developmental delay \\
Setting: USA
\end{tabular}

Interventions

\section{PARENTAL PRESENCE}

1. Parental presence $(n=101)$

2. Oral midazolam $0.5 \mathrm{mg} / \mathrm{kg}$ at least 30 minutes prior $(\mathrm{n}=101)$

3. Control $(n=106)$

A 4th arm of the trial (the ADVANCE behavioural preparation group) was omitted here as it involved participation several days before surgery

All had inhalational induction using oxygen/nitrous oxide/sevoflurane

Outcomes

Anxiety of children (mYPAS).

Parental anxiety (STAI).

Emergence behaviour/delirium - using a 3-point scale ( 1 = no symptoms of emergence delirium, 3 = moderate to severe symptoms, crying, thrashing, need for restraint)

Analgesic requirements in PACU

Discharge time between arrival to PACU and home 
Kain 2007 (Continued)

$\begin{array}{ll}\text { Notes } & \text { All received standard-of-care treatment with a hospital-based surgery preoperative pro- } \\ \text { gramme: a } 20 \text {-minute programme provides information through an orientation tour } \\ \text { of the operating rooms and via interviews by a nurse, an anaesthetist, and a child-life } \\ \text { experimental protocol }\end{array}$

Risk of bias

\begin{tabular}{l|l|l} 
Bias & Authors' judgement & Support for judgement \\
\hline $\begin{array}{l}\text { Random sequence generation (selection } \\
\text { bias) }\end{array}$ & Low risk & Computer-generated random-number table \\
\hline Allocation concealment (selection bias) & Unclear risk & $\begin{array}{l}\text { Randomization sequence was concealed before interventions } \\
\text { were assigned but no details how allocation was concealed were } \\
\text { reported }\end{array}$ \\
\hline
\end{tabular}

Blinding of participants and personnel Unclear risk

Participants not blinded; personnel partially blinded (performance bias)

All outcomes

\begin{tabular}{|c|c|c|}
\hline $\begin{array}{l}\text { Blinding of outcome assessment (detection } \\
\text { bias) } \\
\text { All outcomes }\end{array}$ & Unclear risk & $\begin{array}{l}\text { Raters of videotapes of induction were as blind to group as- } \\
\text { signments as possible (not completely in comparing between } \\
\text { parental presence and absence). Anaesthetist blinded, all other } \\
\text { medical personnel in the recovery room were blinded to group } \\
\text { assignment and preoperative interventions }\end{array}$ \\
\hline
\end{tabular}

\begin{tabular}{l|l|l}
\hline Incomplete outcome data (attrition bias) & Unclear risk & 17 children (7 from the control group; 7 from the parental pres-
\end{tabular} All outcomes ence group; and 3 from the midazolam group) could not receive the designated interventions because of issues related to the operating room schedule: results (except for anxiety) were analysed on an intention-to-treat basis

\begin{tabular}{|c|c|c|}
\hline Selective reporting (reporting bias) & Unclear risk & $\begin{array}{l}\text { Parental anxiety was only reported as all } 3 \text { groups above com- } \\
\text { bined compared with the ADVANCE intervention }\end{array}$ \\
\hline
\end{tabular}

\begin{tabular}{l|l} 
Other bias & Unclear risk $\quad$ No apparent source of other bias
\end{tabular}

Kain 2009

\begin{tabular}{ll}
\hline Methods & RCT \\
\hline Participants & $\begin{array}{l}61 \text { healthy children, ASA I - II scheduled to undergo outpatient surgery under general } \\
\text { anaesthesia who arrived with } 2 \text { parents } \\
58 \text { mothers, } 49 \text { fathers and } 9 \text { other female parents (grandmothers, aunts). Excludes } 3 \\
\text { postrandomization exclusions } \\
\text { Exclusion: a history of chronic illness, prematurity, or developmental delay } \\
\text { Setting: USA }\end{array}$ \\
\end{tabular}


Kain 2009 (Continued)

\begin{tabular}{|c|c|c|}
\hline Interventions & \multicolumn{2}{|c|}{$\begin{array}{l}\text { PARENTAL PRESENCE } \\
\text { 1. 1-parent group }(\mathrm{n}=30) \text { : families were asked which parent would accompany the } \\
\text { child } \\
\text { 2. 2-parent group }(\mathrm{n}=28) \text { : } \\
\text { All participants received inhalation induction with oxygen/nitrous oxide/sevoflurane via } \\
\text { a scented mask }\end{array}$} \\
\hline Outcomes & \multicolumn{2}{|c|}{$\begin{array}{l}\text { Child anxiety at induction: } \mathrm{mYPAS} \\
\text { Child co-operation at induction: induction compliance checklist (ICC) } \\
\text { Parental anxiety after leaving OR: STAI }\end{array}$} \\
\hline \multicolumn{3}{|l|}{ Notes } \\
\hline \multicolumn{3}{|l|}{ Risk of bias } \\
\hline Bias & Authors' judgement & Support for judgement \\
\hline $\begin{array}{l}\text { Random sequence generation (selection } \\
\text { bias) }\end{array}$ & Low risk & Computer-generated random-number table \\
\hline Allocation concealment (selection bias) & Unclear risk & "Concealed until enrolment in the study" \\
\hline $\begin{array}{l}\text { Blinding of participants and personnel } \\
\text { (performance bias) } \\
\text { All outcomes }\end{array}$ & High risk & $\begin{array}{l}\text { The nature of the intervention precluded blinding of partici- } \\
\text { pants }\end{array}$ \\
\hline $\begin{array}{l}\text { Blinding of outcome assessment (detection } \\
\text { bias) } \\
\text { All outcomes }\end{array}$ & Low risk & $\begin{array}{l}\text { Research assistants evaluating outcomes were blind to the study } \\
\text { conditions }\end{array}$ \\
\hline $\begin{array}{l}\text { Incomplete outcome data (attrition bias) } \\
\text { All outcomes }\end{array}$ & Unclear risk & $\begin{array}{l}3 \text { participants dropped out from the study after group assign- } \\
\text { ment ( } 1 \text { in the } 1 \text {-parent group and } 2 \text { in the } 2 \text {-parent group) and } \\
\text { were not included in the report }\end{array}$ \\
\hline Selective reporting (reporting bias) & Low risk & Most expected outcomes were reported \\
\hline Other bias & Low risk & $\begin{array}{l}\text { No other concerns apparent, apart from a higher proportion of } \\
\text { women in the single-parent group compared with the 2-parent } \\
\text { group }\end{array}$ \\
\hline
\end{tabular}

Kazak 2010

\begin{tabular}{ll}
\hline Methods & RCT \\
\hline Participants & $\begin{array}{l}60 \text { healthy children aged } 2-6 \text { years, ASA I - II scheduled for short routine procedures } \\
\text { such as inguinal hernia, circumcision or strabismus } \\
\text { Exclusions: use of sedatives or hypnotics within the last month, use of theophylline } \\
\text { or hepatic enzyme-inducing drugs, presence of severe central nervous system (CNS) }\end{array}$
\end{tabular}


dysfunction or increased intracranial pressure, malformation of the cardiovascular system, hypertonus or hyperthyroidism and refusal to take the entire midazolam dose Setting: Turkey

\begin{tabular}{|c|c|}
\hline Interventions & $\begin{array}{l}\text { PARENTAL PRESENCE } \\
\text { 1. Parental presence alone }(\mathrm{n}=20) \\
\text { 2. Midazolam only }(\mathrm{n}=20): 0.5 \mathrm{mg} / \mathrm{kg} \text { midazolam orally } \\
\text { 3. Midazolam with parental presence }(\mathrm{n}=20): 0.25 \mathrm{mg} / \mathrm{kg} \text { midazolam orally } \\
\text { All children received inhalation induction with oxygen } / \text { nitrous oxide/sevoflurane via } \\
\text { mask }\end{array}$ \\
\hline Outcomes & $\begin{array}{l}\text { Child's anxiety before medication at } 5, \mathbf{1 0}, 15 \text { and } 20 \text { minutes: using a 4-point scale } \\
\text { ( } 1 \text { = panicky, } 4 \text { = friendly) } \\
\text { Child's anxiety after premedication: 4-point scale same as above } \\
\text { Child's anxiety at induction of anaesthesia: 4-point scale same as above } \\
\text { Child's sedation score at 5, 10, } 15 \text { and } 20 \text { minutes: The UMSS ( } 0 \text { = awake and alert, } \\
4 \text { = unarousable) } \\
\text { Child's sedation score after premedication: UMSS same as above } \\
\text { Child's sedation score at induction of anaesthesia: UMSS same as above } \\
\text { Child's postoperative recovery: every } 10 \text { minutes }(10,20,30) \text { - used the FLACC scale } \\
\text { Observer pain scale scores: not described } \\
\text { VAS: not described } \\
\text { Heart rate; before and after induction } \\
\text { Mean arterial blood pressure: before and after induction } \\
\text { Oxygen saturation: before and after induction }\end{array}$ \\
\hline
\end{tabular}

Risk of bias

Bias

Authors' judgement Support for judgement

Random sequence generation (selection Unclear risk "Randomly allocated" bias)

Allocation concealment (selection bias) Unclear risk Sealed envelope (no further details reported)

Blinding of participants and personnel Unclear risk Not reported, but unlikely (performance bias)

All outcomes

Blinding of outcome assessment (detection Unclear risk bias)

Not reported except that the VAS score was evaluated by a physi-

All outcomes

cian in the PACU blinded to the study groups

Incomplete outcome data (attrition bias) Low risk

All outcomes

No losses reported

Non-pharmacological interventions for assisting the induction of anaesthesia in children (Review) 
Kazak 2010 (Continued)

\begin{tabular}{|c|c|c|}
\hline Selective reporting (reporting bias) & Unclear risk & $\begin{array}{l}\text { Most expected outcomes were reported, but only as bar charts } \\
\text { and } \mathrm{P} \text { value }>\text { or }<0.05 \text {; no parental outcomes reported }\end{array}$ \\
\hline Other bias & Low risk & No other concerns apparent \\
\hline
\end{tabular}

MacLaren 2008

\begin{tabular}{l|l}
\hline Methods & RCT \\
\hline Participants & $\begin{array}{l}112 \text { healthy children ages } 2 \text { - } 7 \text { years and their parents, ASA I - II undergoing outpatient } \\
\text { surgery with general anaesthesia } \\
\text { Exclusions: none reported } \\
\text { Setting: USA. }\end{array}$ \\
\hline Interventions & $\begin{array}{l}\text { CHILD/PARENT INTERVENTION (mask introduction/exposure): } \\
\text { 1. Intervention (n }=45) \text { participated in an exposure and shaping procedure in } \\
\text { which they were introduced to the anaesthesia mask and were reinforced for successive } \\
\text { approximations of desired behaviour during induction } \\
\text { 2. Control (n = 58) }\end{array}$ \\
\hline Method of induction: not reported. \\
\hline Outcomes & $\begin{array}{l}\text { Child's anxiety: mYPAS (post-intervention and at induction of anaesthesia) } \\
\text { Child's co-operation with induction procedure: ICC (number of children compliant) } \\
\text { Parent's anxiety: STAI }\end{array}$ \\
\hline Nisk of bias & \\
\hline
\end{tabular}

\begin{tabular}{l|l|l} 
Bias & Authors' judgement & Support for judgement \\
\hline $\begin{array}{l}\text { Random sequence generation (selection } \\
\text { bias) }\end{array}$ & Unclear risk & Not reported \\
\hline Allocation concealment (selection bias) & Unclear risk & $\begin{array}{l}\text { Methods of allocation concealment not reported - “children were } \\
\text { randomly assigned to treatment condition” }\end{array}$ \\
\hline
\end{tabular}

Blinding of participants and personnel Unclear risk Research assistants who administered the mYPAS were not in-

(performance bias) formed of the study aims

All outcomes

\begin{tabular}{|c|c|c|}
\hline $\begin{array}{l}\text { Blinding of outcome assessment (detection } \\
\text { bias) } \\
\text { All outcomes }\end{array}$ & Unclear risk & Not reported \\
\hline
\end{tabular}

Incomplete outcome data (attrition bias) Unclear risk

9 children were missing mYPAS data at all 3 points and were All outcomes therefore excluded from the analyses; not reported which groups these losses were from 
MacLaren 2008 (Continued)

\begin{tabular}{|c|c|c|}
\hline Selective reporting (reporting bias) & Low risk & Most expected outcomes were reported \\
\hline Other bias & High risk & $\begin{array}{l}8 \text { participants with missing mYPAS had values replaced with the } \\
\text { mean mYPAS score; imbalance in numbers randomized to each } \\
\text { group (not clear if this was due to selective attrition) }\end{array}$ \\
\hline
\end{tabular}

McEwen 2007

\begin{tabular}{ll}
\hline Methods & RCT \\
\hline Participants & 122 parents \\
& Inclusion criteria: Parents of children booked for day surgery - children were ASA I, II \\
& or III; and under 16 years \\
& Exclusion: Parents with a poor command of English or literacy problems \\
& Setting: Day surgery, children's hospital, UK \\
\hline
\end{tabular}

Interventions

\section{PARENT INTERVENTIONS}

1. 8-minute video after parents completed the first questionnaire $(\mathrm{n}=55)$

2. Control $(n=56)$

Video: illustrated the events and procedures surrounding a child's admission to hospital for day surgery, including induction of anaesthesia

Questionnaire: All parents completed the APAIS questionnaires on the day of admission to surgery and then again just before accompanying their child to the anaesthetic room All parents were given the normal preoperative parental preparation Method of induction not reported

Outcomes

Parental anxiety: APAIS anxiety score; APAIS desire for information score; APAIS total score

Notes

\section{Risk of bias}

\section{Bias}

\section{Authors' judgement Support for judgement}

Random sequence generation (selection Low risk bias)

\begin{tabular}{l|l|l} 
Allocation concealment (selection bias) & Unclear risk & Sealed envelopes (no further details provided) \\
\hline $\begin{array}{l}\text { Blinding of participants and personnel } \\
\text { (performance bias) } \\
\text { All outcomes }\end{array}$ & Not reported but unlikely \\
\hline
\end{tabular}

Blinding of outcome assessment (detection Unclear risk Not reported bias)

All outcomes 
McEwen 2007 (Continued)

\begin{tabular}{lll}
$\begin{array}{l}\text { Incomplete outcome data (attrition bias) } \\
\text { All outcomes }\end{array}$ & Unclear risk & $\begin{array}{l}11 / 122(9 \%) \text { parents excluded after randomization due to in- } \\
\text { complete data; losses not reported by group }\end{array}$ \\
\hline Selective reporting (reporting bias) & Unclear risk & No child outcomes reported \\
\hline Other bias & Low risk & No apparent evidence of other bias \\
\hline
\end{tabular}

Meisel 2009

\begin{tabular}{ll}
\hline Methods & Quasi-RCT \\
\hline Participants & $\begin{array}{l}\text { 61 children ages 3 - } 12 \text { years, scheduled to undergo general anaesthesia for minor surgery } \\
\text { Exclusion: previous surgery, difficulties understanding the language, psychological def- } \\
\text { ciencies, sensitivity to clowns } \\
\text { Setting: Spain }\end{array}$ \\
\hline
\end{tabular}

Interventions

\section{CHILD INTERVENTIONS: CLOWNS/CLOWN DOCTORS}

1. Intervention group: children spent 7 minutes with clowns before anaesthesia $(\mathrm{n}=$ 28)

2. Control group: no clowns $(\mathrm{n}=33)$

Method of induction: not reported.

Outcomes

Child's distress: FAS was completed by the psychologist before surgery (Time 2) and before anaesthesia (Time 4)

Child's postoperative maladaptive behaviours: The parent completed the PHBQ before surgery in outpatient (Time 1) and 1 week after surgery (Time 6)

Surgery was conducted at Time 5 .

Notes Paper written in Spanish

\section{Risk of bias}

\begin{tabular}{l|l|l}
\hline Bias & Authors' judgement & Support for judgement \\
\hline $\begin{array}{l}\text { Random sequence generation (selection } \\
\text { bias) }\end{array}$ & High risk & By day of week \\
\hline $\begin{array}{l}\text { Allocation concealment (selection bias) } \\
\text { Blinding of participants and personnel } \\
\begin{array}{l}\text { (performance bias) } \\
\text { All outcomes }\end{array}\end{array}$ & High risk & By day of week \\
\hline $\begin{array}{l}\text { Blinding of outcome assessment (detection } \\
\text { bias) } \\
\text { All outcomes }\end{array}$ & Unclear risk & Not reported but unlikely \\
\hline
\end{tabular}


Meisel 2009 (Continued)

\begin{tabular}{|c|c|c|}
\hline $\begin{array}{l}\text { Incomplete outcome data (attrition bias) } \\
\text { All outcomes }\end{array}$ & Low risk & $\begin{array}{l}\text { The final sample consisted of } 61 \text { participants and no losses were } \\
\text { reported }\end{array}$ \\
\hline Selective reporting (reporting bias) & Low risk & Most expected outcomes were reported \\
\hline Other bias & Unclear risk & $\begin{array}{l}\text { No apparent evidence of other sources of bias, apart from base- } \\
\text { line imbalance in numbers allocated to each group }\end{array}$ \\
\hline
\end{tabular}

Mifflin 2012

\begin{tabular}{ll}
\hline Methods & RCT \\
\hline Participants & $\begin{array}{l}89 \text { children ages } 2 \text { - } 10 \text { years, ASA I or II, who presented for ambulatory surgery } \\
\text { Inclusion criteria: No previous exposure to anaesthesia or surgery, presented for ambu- } \\
\text { latory surgery } \\
\text { Exclusion; Requiring emergency surgery, those with language barriers, those with devel- } \\
\text { opmental disabilities and those taking psychoactive medications } \\
\text { Setting: Canada }\end{array}$ \\
\hline
\end{tabular}

Interventions

\section{CHILD/PARENT INTERVENTION (PASSIVE):}

1. Video clip distraction $(n=42)$ : children were asked to select from a list of ageappropriate videos and these were played on a large screen while the mask was held close to their face

2. Control group $(n=47)$ : anaesthetists used their usual traditional distraction techniques (imagery, story telling, game playing, non-procedural talk, humour) Method of induction: Using a circle system, oxygen $(2 \mathrm{~L} / \mathrm{min}$ ) and nitrous oxide (4 L/ $\min$ ) were offered for the 1 st minute and then sevoflurane was added in increments to reach the maximum vaporizer setting of $8 \%$ within a few breaths

Outcomes

Child's anxiety: mYPAS

Notes

Risk of bias

Bias

Authors' judgement Support for judgement

Random sequence generation (selection Low risk Random-number generator

bias)

\begin{tabular}{lll}
\hline Allocation concealment (selection bias) & Unclear risk & Sealed envelopes
\end{tabular}

Blinding of participants and personnel High risk

Not reported but unlikely

(performance bias)

All outcomes

Non-pharmacological interventions for assisting the induction of anaesthesia in children (Review) 
Mifflin 2012 (Continued)

\begin{tabular}{ll|l}
\hline $\begin{array}{l}\text { Blinding of outcome assessment (detection } \\
\text { bias) } \\
\text { All outcomes }\end{array}$ & Unclear risk & Not reported \\
\hline $\begin{array}{l}\text { Incomplete outcome data (attrition bias) } \\
\text { All outcomes }\end{array}$ & Low risk & $\begin{array}{l}1 \text { participant from the intervention group was excluded from } \\
\text { analysis (due to medication with midazolam) }\end{array}$ \\
\hline Selective reporting (reporting bias) & Unclear risk & Only some of the expected outcomes were reported \\
\hline Other bias & Low risk & Slight imbalance in numbers randomized to each group \\
\hline
\end{tabular}

Palermo 2000

\begin{tabular}{ll}
\hline Methods & RCT \\
\hline Participants & $\begin{array}{l}83 \text { children ages } 1-12 \text { months, ASA I - II, outpatient surgery } \\
\\
\text { Exclusions: airway-related disorders } \\
\text { Setting: USA }\end{array}$ \\
\hline
\end{tabular}

Interventions

PARENTAL PRESENCE

1. Parental presence $(n=37)$

2. Control - no parent present $(n=36)$

Induction technique not reported

Outcomes

Child behaviour scale developed by Hannallah \& Rosales was used to rate anxiety of children (low distress level $1-2$, extreme distress, body flailing $=4$ )

Parental anxiety was measured by STAI

Parental healthcare attitudes were assessed by parent version of the HCAQ.

Parents filled in satisfaction questionnaires when children returned to the recovery room ( 1 = not satisfied, 7 = extremely satisfied)

Notes

Risk of bias

Bias

Authors' judgement Support for judgement

Random sequence generation (selection Unclear risk "Randomly assigned" - no further details reported bias)

Allocation concealment (selection bias) Unclear risk "Randomly assigned" - no further details reported

Blinding of participants and personnel High risk (performance bias)

All outcomes

Non-pharmacological interventions for assisting the induction of anaesthesia in children (Review) 
Palermo 2000 (Continued)

\begin{tabular}{l|l|l}
$\begin{array}{l}\text { Blinding of outcome assessment (detection } \\
\text { bias) } \\
\text { All outcomes }\end{array}$ & Unclear risk & $\begin{array}{l}\text { Child behaviour graded by anaesthetists who were not blinded, } \\
\text { other anxiety measurement obtained from questionnaire filled } \\
\text { in by parents }\end{array}$ \\
\hline $\begin{array}{l}\text { Incomplete outcome data (attrition bias) } \\
\text { All outcomes }\end{array}$ & Unclear risk & $\begin{array}{l}10 \text { losses - due to "surgery cancellations and missing data"; } \\
\text { groups not reported }\end{array}$ \\
\hline Selective reporting (reporting bias) & High risk & Only child anxiety was reported \\
\hline Other bias & Low risk & No apparent evidence of other sources of bias \\
\hline
\end{tabular}

Patel 2006

\begin{tabular}{|c|c|}
\hline Methods & RCT \\
\hline Participants & $\begin{array}{l}112 \text { children aged } 4-12 \text { years undergoing outpatient surgery } \\
\text { Exclusions: emergency surgery, developmental disabilities, chronic illness, psychoactive } \\
\text { medications, children having repeated surgery } \\
\text { Setting: USA }\end{array}$ \\
\hline Interventions & $\begin{array}{l}\text { CHILD INTERVENTION (interactive) } \\
\text { 1. Video game }- \text { hand-held }(\mathrm{n}=38) \\
\text { 2. Midazolam } 0.5 \mathrm{mg} / \mathrm{kg} \text { orally }(\mathrm{n}=38) \\
\text { 3. No intervention control }(\mathrm{n}=36) \\
\text { All children had parents present during mask induction of anaesthesia } \\
\text { Inhalational induction with sevoflurane, nitrous oxide, oxygen }\end{array}$ \\
\hline Outcomes & $\begin{array}{l}\text { Child anxiety; child behaviour mYPAS and PHBQ administered preoperatively; a } \\
\text { second mYPAS was performed just prior to and during anaesthesia induction } \\
\text { PHBQ } 7 \text { and } 10 \text { days postoperatively }\end{array}$ \\
\hline Notes & \\
\hline
\end{tabular}

\section{Risk of bias}

\begin{tabular}{l|l|l} 
Bias & Authors' judgement & Support for judgement \\
\hline $\begin{array}{l}\text { Random sequence generation (selection } \\
\text { bias) }\end{array}$ & Unclear risk & "Randomized" - no further details given \\
\hline $\begin{array}{l}\text { Allocation concealment (selection bias) } \\
\begin{array}{l}\text { Blinding of participants and personnel } \\
\text { (performance bias) }\end{array}\end{array}$ & High risk & $\begin{array}{l}\text { Not reported but blinding unlikely due to the nature of the } \\
\text { intervention }\end{array}$
\end{tabular}

All outcomes 
Patel 2006 (Continued)

\begin{tabular}{|c|c|c|}
\hline $\begin{array}{l}\text { Blinding of outcome assessment (detection } \\
\text { bias) } \\
\text { All outcomes }\end{array}$ & Unclear risk & $\begin{array}{l}\text { Independent observer performed anxiety testing during induc- } \\
\text { tion of anaesthesia but could not be blinded due to presence of } \\
\text { video game at induction }\end{array}$ \\
\hline $\begin{array}{l}\text { Incomplete outcome data (attrition bias) } \\
\text { All outcomes }\end{array}$ & Low risk & No losses reported \\
\hline Selective reporting (reporting bias) & Unclear risk & Limited number of outcomes reported \\
\hline Other bias & Low risk & No apparent evidence of other sources of bias \\
\hline
\end{tabular}

\section{Vagnoli 2005}

\begin{tabular}{l|l}
\hline Methods & RCT \\
\hline Participants & $\begin{array}{l}\text { 40 Italian children ages 5 - 12, ASA I - II, minor day surgery } \\
\text { Exclusion: chronic illness, premature birth, premedications, previous anaesthesia } \\
\text { Setting: Anna Meyer Children's Hospital, Italy }\end{array}$ \\
\hline Interventions & $\begin{array}{l}\text { CHILD INTERVENTION (interactive) } \\
1 . \text { Clown group - a pair of clowns spent time with child in preoperative room, 30 } \\
\text { minutes prior and stay interacting with children before entering operating room. } \\
\text { Accompanied children and parents during induction (n }=20) \\
\text { 2. Parental presence only (n = 20) }\end{array}$ \\
\hline All children had inhalational induction with oxygen/nitrous oxide/sevoflurane \\
\hline Outcomes & $\begin{array}{l}\text { mYPAS was used to measured anxiety of children } \\
\text { STAI measured parental anxiety } \\
\text { Health professionals completed a questionnaire to express their opinion of the presence } \\
\text { of clowns during induction }\end{array}$ \\
\hline Notes & \begin{tabular}{l}
\hline \\
\hline
\end{tabular} \\
\hline
\end{tabular}

\section{Risk of bias}

Bias Authors' judgement Support for judgement

Random sequence generation (selection Unclear risk "Randomly assigned"; no further details reported bias)

\begin{tabular}{lll}
\hline Allocation concealment (selection bias) & Unclear risk & As above \\
\hline
\end{tabular}

Blinding of participants and personnel High risk Not feasible to blind (performance bias)

All outcomes 
Vagnoli 2005 (Continued)

\begin{tabular}{lll}
\hline $\begin{array}{l}\text { Blinding of outcome assessment (detection } \\
\text { bias) } \\
\text { All outcomes }\end{array}$ & High risk & $\begin{array}{l}2 \text { psychologist observers, present during the whole process, were } \\
\text { not blinded }\end{array}$ \\
\hline $\begin{array}{l}\text { Incomplete outcome data (attrition bias) } \\
\text { All outcomes }\end{array}$ & Low risk & None reported \\
\hline Selective reporting (reporting bias) & Unclear risk & Not all expected outcomes were reported \\
\hline Other bias & Unclear risk & No apparent evidence of other bias \\
\hline
\end{tabular}

\section{Vagnoli 2010}

\begin{tabular}{l|l}
\hline Methods & RCT \\
\hline Participants & $\begin{array}{l}75 \text { children, ages } 5-12 \text { years, ASA I - II scheduled to undergo general anaesthesia for } \\
\text { minor surgery } \\
\text { Exclusions: non-Italian children, a history of chronic illness, premature birth, develop- } \\
\text { mental delay or previous anaesthetic experience } \\
\text { Setting: Italy }\end{array}$ \\
\hline
\end{tabular}

Interventions

\section{CHILD/PARENT INTERVENTIONS: CLOWN DOCTORS/CLOWNS}

1. Clown group $(n=25)$ : were accompanied into the preoperative room by 2 clowns and a parent

2. Premedication group (PG) $(\mathrm{n}=25)$ : were premedicated with $0.5 \mathrm{mg} / \mathrm{kg}$ oral midazolam 45 minutes before surgery and parent was present throughout the anaesthesia-induction process

3. Control group (CG) $(n=25)$ : children were accompanied in the OR by 1 parent only without any clowns

All participants received inhalation induction with oxygen/nitrous oxide/sevoflurane via a scented mask

Outcomes

Child's anxiety in the waiting room and induction room: mYPAS

Parent's anxiety (STAI state and trait): STAI

Notes

\section{Risk of bias}

Bias

Random sequence generation (selection Low risk bias)

Allocation concealment (selection bias)
Unclear risk

Methods of allocation concealment not reported 
Blinding of participants and personnel Unclear risk (performance bias)

All outcomes
The anaesthetist, the parents and other observers were kept blinded to the purpose of the study and the groups involved. However it was impossible to be blinded entirely to assignment for the children in the clown group. In addition parents in the premedication group were told that their children had been given a drug

"Other observers were blinded to the purpose of the study and the groups involved" - we have interpreted this to indicate that outcome assessment was blinded (although this may have been difficult to achieve)
Blinding of outcome assessment (detection Low risk bias)

All outcomes
Limited number of outcomes

Incomplete outcome data (attrition bias) Low risk No losses reported

All outcomes

\begin{tabular}{llll} 
Selective reporting (reporting bias) & Unclear risk & Limited number of outcomes \\
\hline Other bias & Low risk & No apparent evidence of other bias
\end{tabular}

\section{Wang 2004}

\begin{tabular}{ll}
\hline Methods & RCT \\
\hline Participants & $\begin{array}{l}67 \text { children ages } 2-7, \text { ASA I - II, outpatient surgery under GA } \\
\text { Exclusion: chronic illness, prematurity or developmental delay, CNS dysfunction. Moth- } \\
\text { ers with a history of psychological illness (e.g. anxiety or depression) } \\
\text { Setting: Yale-New Haven Children's Hospital, USA }\end{array}$ \\
\hline
\end{tabular}

Interventions

\section{PARENT INTERVENTIONS}

1. Acupunture group (parents) - 3 occlusion auricular press needles at the external ear (points known to reduce anxiety) ipsilateral to the dominant hand $(\mathrm{n}=34)$

2. Sham control group - 3 auricular press needles at the external ear (points not known to reduce anxiety) ipsilateral to dominant hand $(\mathrm{n}=33)$

All children had inhalational induction with oxygen/nitrous oxide/sevoflurane

Outcomes Anxiety of children was measured by mYPAS.

Induction co-operation was measured using the ICC

STAI, heart rate and blood pressure were used to rate parental anxiety

Notes

\section{Risk of bias}

\begin{tabular}{l|l|l}
\hline Bias & Authors' judgement & Support for judgement \\
\hline $\begin{array}{l}\text { Random sequence generation (selection } \\
\text { bias) }\end{array}$ & Low risk & Random-number table generated by computer \\
\hline
\end{tabular}




\begin{tabular}{|c|c|c|}
\hline Allocation concealment (selection bias) & Unclear risk & $\begin{array}{l}\text { Randomization code was broken by acupuncturist after parent } \\
\text { recruitment and just before the intervention was administered }\end{array}$ \\
\hline $\begin{array}{l}\text { Blinding of participants and personnel } \\
\text { (performance bias) } \\
\text { All outcomes }\end{array}$ & Low risk & Research assistant and parent blinded to group assignment \\
\hline $\begin{array}{l}\text { Blinding of outcome assessment (detection } \\
\text { bias) } \\
\text { All outcomes }\end{array}$ & Low risk & Anaesthetist blinded to group assignment \\
\hline $\begin{array}{l}\text { Incomplete outcome data (attrition bias) } \\
\text { All outcomes }\end{array}$ & Unclear risk & None reported \\
\hline Selective reporting (reporting bias) & Low risk & Most expected outcomes were reported \\
\hline Other bias & Low risk & No apparent evidence of other bias \\
\hline
\end{tabular}

\section{Wright 2010}

\begin{tabular}{|c|c|}
\hline Methods & RCT \\
\hline Participants & $\begin{array}{l}61 \text { children, ages } 3-6 \text { years, scheduled for various day surgery procedures such as ears, } \\
\text { nose and throat (ENT) and urology } \\
\text { Exclusion: children with a history of gastro-oesophageal reflux disease, central nervous } \\
\text { system disease, psychiatric disease, liver or renal disease, cancer, or neurological or cog- } \\
\text { nitive impairment or disease } \\
\text { Setting: Canada }\end{array}$ \\
\hline
\end{tabular}

Interventions
PARENTAL PRESENCE

1. Parental presence $(\mathrm{n}=30)$

2. Parental absence $(\mathrm{n}=31)$

Induction technique not reported

No participants received premedication

Outcomes

Notes
Child's anxiety at induction (anaesthetic mask placement): mYPAS

The analysis reported in this study was the primary focus of a larger set of studies

\section{Risk of bias}

\section{Bias}

Random sequence generation (selection Low risk bias)

Allocation concealment (selection bias)
Unclear risk

\section{Authors' judgement Support for judgement}

Random-number generator

The randomization code was placed in a sealed envelope 
Wright 2010 (Continued)

\begin{tabular}{|c|c|c|}
\hline $\begin{array}{l}\text { Blinding of participants and personnel } \\
\text { (performance bias) } \\
\text { All outcomes }\end{array}$ & High risk & $\begin{array}{l}\text { Parents, children, anaesthetists and research assistants were blind } \\
\text { to group assignment until meeting with the anaesthetist just } \\
\text { before leaving the day surgery room, but binding unlikely }\end{array}$ \\
\hline $\begin{array}{l}\text { Blinding of outcome assessment (detection } \\
\text { bias) } \\
\text { All outcomes }\end{array}$ & Low risk & $\begin{array}{l}1 \text { research assistant was present throughout the procedure to } \\
\text { complete observer anxiety ratings. A } 2 \text { nd research assistant } \\
\text { videotaped the induction. A } 2 \text { nd rater independently scored the } \\
\text { mYPAS later via video tape for a random } 20 \% \text { of the participant }\end{array}$ \\
\hline $\begin{array}{l}\text { Incomplete outcome data (attrition bias) } \\
\text { All outcomes }\end{array}$ & Low risk & No losses reported \\
\hline Selective reporting (reporting bias) & Unclear risk & Only child anxiety was reported \\
\hline Other bias & Low risk & No apparent sources of other bias \\
\hline
\end{tabular}

Zuwala 2001

$\begin{array}{ll}\text { Methods } & \text { RCT }\end{array}$

Participants 80 children ages 10 months to 10 years. ASA I - II for elective myringotomy and tonsillectomy

Exclusion: previous surgery, children with a pregnant mother, and children whose anaesthetist or surgeon refused co-operation

Setting: USA

Interventions

\section{PARENT INTERVENTIONS}

1. Educational pamphlet explained the event expected during the perioperative period and a 2-minute instructional video demonstrating a paediatric mask induction $(\mathrm{n}=40)$

2. Educational pamphlet alone $(n=40)$

Inhalational induction (no further details provided)

Outcomes

Parental assessment of child behaviour during induction using behavioural scale (5item scale from quiet and co-operative to turbulent and uncontrollable) but no standard deviations were reported

Parental anxiety was measured using STAI, heart rate and blood pressure

Parents completed an opinion survey at discharge about their experience accompanying their child into induction

A postoperative questionnaire on behavioural changes in children was completed 2 weeks postoperatively

Notes

Risk of bias

Bias

Authors' judgement Support for judgement

Non-pharmacological interventions for assisting the induction of anaesthesia in children (Review)

Copyright @ 2015 The Cochrane Collaboration. Published by John Wiley \& Sons, Ltd. 


\begin{tabular}{l|l|l}
\hline $\begin{array}{l}\text { Random sequence generation (selection } \\
\text { bias) }\end{array}$ & Unclear risk & $\begin{array}{l}\text { Not reported: "parents of each patient were randomized to } 2 \\
\text { different interventions..." }\end{array}$ \\
\hline $\begin{array}{l}\text { Allocation concealment (selection bias) } \\
\text { Blinding of participants and personnel } \\
\text { (performance bias) } \\
\text { All outcomes }\end{array}$ & Unclear risk & Method of allocation concealment not reported \\
\hline $\begin{array}{l}\text { Blinding of outcome assessment (detection } \\
\text { bias) } \\
\text { All outcomes }\end{array}$ & Unclear risk & $\begin{array}{l}\text { Parents and children old enough to comply were instructed not } \\
\text { to reveal to the raters their methods of preparation }\end{array}$ \\
\hline $\begin{array}{l}\text { Incomplete outcome data (attrition bias) } \\
\text { All outcomes }\end{array}$ & Low risk & Not reported \\
\hline $\begin{array}{l}\text { Selective reporting (reporting bias) } \\
\text { Other bias }\end{array}$ & Unclear risk & $\begin{array}{l}\text { Child anxiety was not reported; and standard deviations for child } \\
\text { behaviour were not reported }\end{array}$ \\
\hline
\end{tabular}

APAIS: Amsterdam Preoperative Anxiety and Information Scale

ASA: American Society of Anesthesiologists

CARS: clinical anxiety rating scale

CSWQ: The Child Surgery Worries Questionnaire

EAS: Emotionality Activity Sociability

FAS: Facial Affective Scale

FLACC: Face, Legs, Activity, Cry and Consolability

GA: general anaesthetic

HCAQ: health care attitudes questionnaire

ICC: Induction Compliance Checklist

mYPAS: modified Yale preoperative anxiety scale

OR: operating room

PACU: post-anaesthesia care unit

PBRS: Procedural Behavioural Rating Scale

PHBQ: Posthospitalisation Behavior Questionnaire

PONV: postoperative nausea and vomiting

RCT: randomized controlled trial

SAM: Self-Assessment Mannequin

SPRS: Steward's Postoperative Recovery Scale

STAI: State Trait Anxiety Inventory

UMSS: University of Michigan Sedation Scale

VAS: Visual Analogue Scale

YPAS: Yale preoperative anxiety scale 
Characteristics of excluded studies [ordered by study ID]

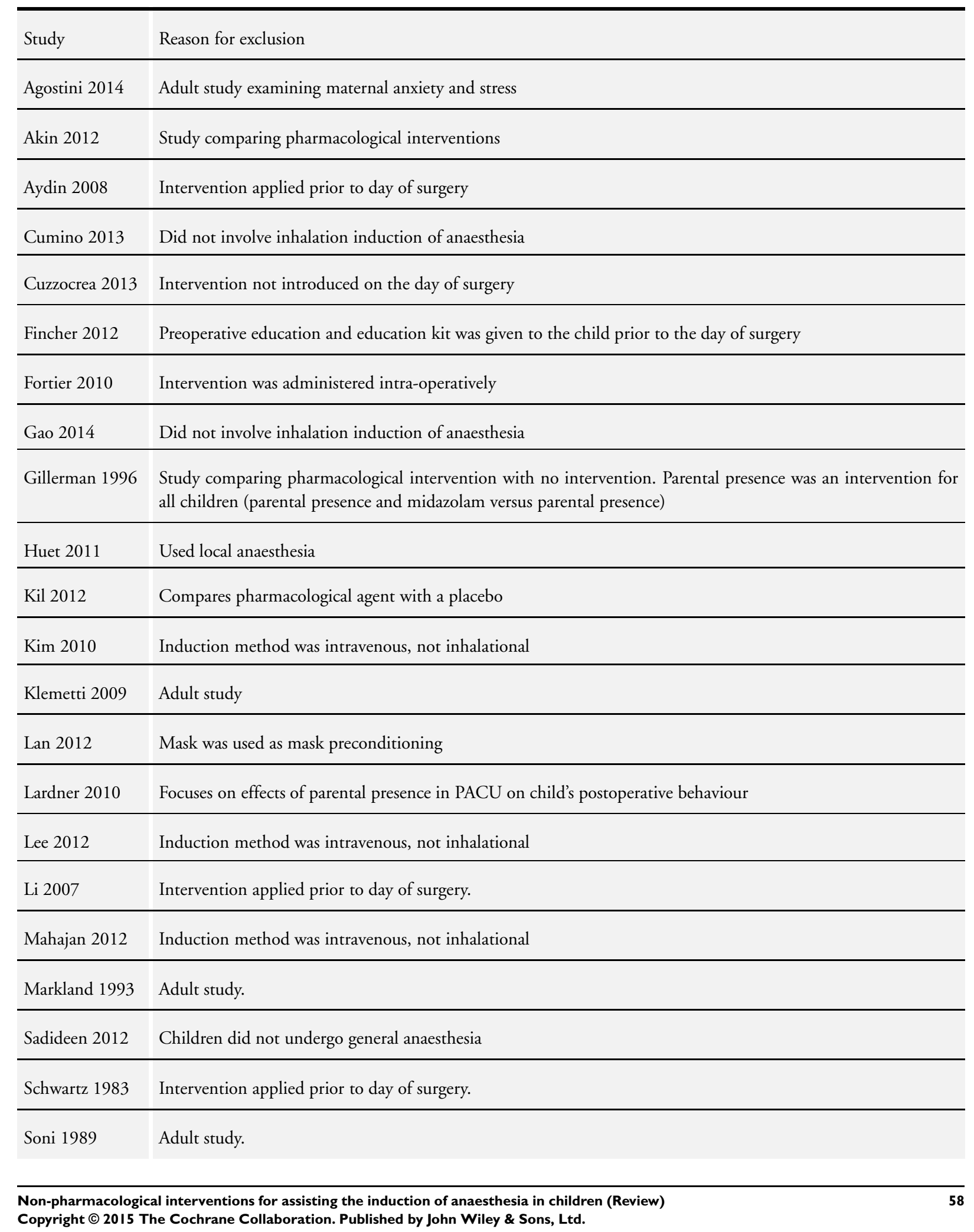


(Continued)

Tripi 2004 This was a comparison of parental presence at induction with parental presence both at induction and at emergence

Wang $2005 \quad$ Not clear whether outcomes were measured at induction

Wang $2008 \quad$ Not clear whether outcomes were measured at induction

PACU: post-anaesthesia care unit

Characteristics of studies awaiting assessment [ordered by study ID]

Kerimoglu 2013

Methods RCT

Participants 96 children aged $4-9$ years undergoing ambulatory surgery

Exclusion: ASA > II; emergency surgery; psychoactive medication; history of severe sleep apnoea, chronic illness, or cognitive dysfunction

Setting: SUNY Downstate Medical Center, Brooklyn, NY (USA)

Interventions CHILD INTERVENTION (video glasses as a distraction tool)

1. Midazolam $0.3 \mathrm{mg} / \mathrm{kg},(\mathrm{n}=32)$

2. Video glasses (Vuzix®, Vuzix Corporation, Rochester, NY) connected to a portable media player $(\mathrm{n}=32)$

3. Both midazolam and video glasses $(n=32)$

Outcomes Anxiety was measured using the modified Yale Preoperative Anxiety Scale before the intervention, 20 minutes later during transport to the operating room, and then during anaesthesia induction

Notes 
DATA ANDANALYSES

Comparison 1. Parental presence versus no parental presence

\begin{tabular}{|c|c|c|c|c|}
\hline Outcome or subgroup title & $\begin{array}{l}\text { No. of } \\
\text { studies }\end{array}$ & $\begin{array}{c}\text { No. of } \\
\text { participants }\end{array}$ & Statistical method & Effect size \\
\hline 1 anxiety during induction & 5 & 557 & Std. Mean Difference (IV, Fixed, 95\% CI) & $0.03[-0.14,0.20]$ \\
\hline 1.1 GMS total & 1 & 130 & Std. Mean Difference (IV, Fixed, 95\% CI) & $0.0[-0.34,0.34]$ \\
\hline 1.2 Child behaviour scale & 1 & 73 & Std. Mean Difference (IV, Fixed, 95\% CI) & $0.40[-0.07,0.86]$ \\
\hline 1.3 mYPAS & 2 & 254 & Std. Mean Difference (IV, Fixed, 95\% CI) & $-0.05[-0.29,0.20]$ \\
\hline 1.44 point scale $(1=$ agitated $)$ & 1 & 100 & Std. Mean Difference (IV, Fixed, 95\% CI) & $0.0[-0.39,0.39]$ \\
\hline 2 anxiety during induction & & & Other data & No numeric data \\
\hline $2.1 \mathrm{VAS}$ & & & Other data & No numeric data \\
\hline $2.2 \mathrm{mYPAS}$ & & & Other data & No numeric data \\
\hline 2.3 serum cortisol $(\mathrm{mcg} / \mathrm{ml})$ & & & Other data & No numeric data \\
\hline $\begin{array}{l}3 \text { anxiety during induction } \\
\quad \text { (parental anxiety subgroup) }\end{array}$ & 1 & & Mean Difference (IV, Fixed, 95\% CI) & Subtotals only \\
\hline 3.1 GMS anxious parent & 1 & 49 & Mean Difference (IV, Fixed, 95\% CI) & $1.1[0.26,1.94]$ \\
\hline 3.2 GMS calm parent & 1 & 63 & Mean Difference (IV, Fixed, 95\% CI) & $-0.10[-0.94,0.74]$ \\
\hline 4 cooperation during induction & & & Other data & No numeric data \\
\hline 4.1 VAS & & & Other data & No numeric data \\
\hline 4.2 ICC > 6 (poor) & & & Other data & No numeric data \\
\hline $\begin{array}{l}\text { 4.3 Quality of mask induction } \\
\text { (out of } 3 \text { - } 3 \text { worst) }\end{array}$ & & & Other data & No numeric data \\
\hline 5 anxiety/distress before induction & 1 & & Mean Difference (IV, Fixed, 95\% CI) & Subtotals only \\
\hline $\begin{array}{l}5.1 \text { separation from parent } \\
\text { (mYPAS) }\end{array}$ & 1 & 61 & Mean Difference (IV, Fixed, 95\% CI) & $\begin{array}{l}-12.16[-19.90,-4 \\
42]\end{array}$ \\
\hline $\begin{array}{l}6 \text { parental anxiety (on day of } \\
\text { surgery) }\end{array}$ & 6 & & Mean Difference (IV, Random, 95\% CI) & Subtotals only \\
\hline 6.1 VAS total & 1 & 125 & Mean Difference (IV, Random, 95\% CI) & $1.80[-10.43,14.03]$ \\
\hline 6.2 STAI & 1 & 73 & Mean Difference (IV, Random, 95\% CI) & $2.0[-0.30,4.30]$ \\
\hline 6.3 STAI (trait) & 1 & 100 & Mean Difference (IV, Random, 95\% CI) & $1.0[-2.34,4.34]$ \\
\hline 6.4 STAI (state) & 3 & 239 & Mean Difference (IV, Random, 95\% CI) & $-1.74[-4.55,1.07]$ \\
\hline $\begin{array}{l}6.5 \text { systolic blood pressure } \\
(\mathrm{mmHg})\end{array}$ & 2 & 137 & Mean Difference (IV, Random, 95\% CI) & $-1.39[-6.18,3.40]$ \\
\hline $\begin{array}{l}6.6 \text { diastolic blood pressure } \\
(\mathrm{mmHg})\end{array}$ & 2 & 137 & Mean Difference (IV, Random, 95\% CI) & $-1.51[-4.68,1.65]$ \\
\hline 6.7 heart rate & 1 & 84 & Mean Difference (IV, Random, 95\% CI) & $-1.0[-4.88,2.88]$ \\
\hline $\begin{array}{l}7 \text { parental anxiety (physiological } \\
\text { signs) }\end{array}$ & 1 & & Risk Ratio (M-H, Fixed, 95\% CI) & Subtotals only \\
\hline 7.1 isolated ventricular ectopy & 1 & 53 & Risk Ratio (M-H, Fixed, 95\% CI) & $0.83[0.18,3.73]$ \\
\hline $\begin{array}{l}7.2 \text { single premature atrial } \\
\text { contractions }\end{array}$ & 1 & 53 & Risk Ratio (M-H, Fixed, 95\% CI) & $0.55[0.10,3.04]$ \\
\hline $\begin{array}{l}8 \text { parental anxiety during } \\
\text { induction (parental anxiety } \\
\text { subgroup) }\end{array}$ & 1 & & Mean Difference (IV, Fixed, 95\% CI) & Subtotals only \\
\hline 8.1 VAS anxious parent & 1 & 49 & Mean Difference (IV, Fixed, 95\% CI) & $16.10[2.39,29.81]$ \\
\hline 8.2 VAS calm parent & 1 & 63 & Mean Difference (IV, Fixed, 95\% CI) & $\begin{array}{l}-10.90[-27.84,6 . \\
04]\end{array}$ \\
\hline
\end{tabular}

Non-pharmacological interventions for assisting the induction of anaesthesia in children (Review) 
9 parental anxiety postop 9.1 PQ 1 week postop

10 parental anxiety

11 emergence delirium

12 emergence delirium

12.1 postoperative excitement score

12.2 emergence behaviour (out of 5 - 5 worst)

13 time taken for induction (minutes)

14 negative behaviour postop 14.1 HFI at 1 week 14.2 BQ at 1 week $14.3 \mathrm{BQ}$ at 2 weeks 14.4 BQ at 6 months

15 negative behaviour postop 15.12 weeks postop

16 parental satisfaction 16.1 overall 16.2 anaesthetists 16.3 nursing staff

17 parental satisfaction 17.1 overall experience 17.2 admitting 17.3 preparation 17.4 communication

17.5 attention to concern

17.6 addressing fear and pain

17.7 emotional support

17.8 overall

17.9 anaesthetists

17.10 nursing staff

18 parental satisfaction
Mean Difference (IV, Fixed, 95\% CI)

121

Mean Difference (IV, Fixed, 95\% CI)

Other data

Risk Ratio (M-H, Fixed, 95\% CI)

Other data

Other data

Other data

Mean Difference (IV, Random, 95\% CI)

Mean Difference (IV, Fixed, 95\% CI)

Mean Difference (IV, Fixed, 95\% CI)

Mean Difference (IV, Fixed, 95\% CI)

Mean Difference (IV, Fixed, 95\% CI)

Mean Difference (IV, Fixed, 95\% CI)

Risk Ratio (M-H, Fixed, 95\% CI)

Risk Ratio (M-H, Fixed, 95\% CI)

Risk Ratio (M-H, Fixed, 95\% CI)

Risk Ratio (M-H, Fixed, 95\% CI)

Risk Ratio (M-H, Fixed, 95\% CI)

Risk Ratio (M-H, Fixed, 95\% CI)

Mean Difference (IV, Fixed, 95\% CI)

Mean Difference (IV, Fixed, 95\% CI)

Mean Difference (IV, Fixed, 95\% CI)

Mean Difference (IV, Fixed, 95\% CI)

Mean Difference (IV, Fixed, 95\% CI)

Mean Difference (IV, Fixed, 95\% CI)

Mean Difference (IV, Fixed, 95\% CI)

Mean Difference (IV, Fixed, 95\% CI)

Mean Difference (IV, Fixed, 95\% CI)

Mean Difference (IV, Fixed, 95\% CI)

Mean Difference (IV, Fixed, 95\% CI)

Other data
Subtotals only 0.20 [0.02, 0.38]

No numeric data 0.66 [0.37, 1.18]

No numeric data

No numeric data

No numeric data

$-0.94[-2.41,0.53]$

Subtotals only

$0.10[-0.19,0.39]$

$0.0[-0.07,0.07]$

$0.0[-2.42,2.42]$

$1.0[-2.23,4.23]$

$0.98[0.52,1.83]$

0.98 [0.52, 1.83]

Subtotals only

$1.09[0.93,1.27]$

$1.01[0.84,1.22]$

1.13 [0.97, 1.32]

Subtotals only

$-0.20[-0.36,-0.04]$

$0.0[-0.28,0.28]$

$-0.10[-0.31,0.11]$

$0.10[-0.13,0.33]$

$-0.10[-0.31,0.11]$

$0.0[-0.23,0.23]$

$-0.20[-0.45,0.05]$

$-1.0[-14.69,12.69]$

$8.0[-8.15,24.15]$

$3.00[-12.93,18.93]$

No numeric data

Comparison 2. Two parents versus one parent

\begin{tabular}{|c|c|c|c|c|}
\hline Outcome or subgroup title & $\begin{array}{l}\text { No. of } \\
\text { studies }\end{array}$ & $\begin{array}{c}\text { No. of } \\
\text { participants }\end{array}$ & Statistical method & Effect size \\
\hline 1 anxiety at induction & & & Other data & No numeric data \\
\hline $1.1 \mathrm{mYPAS}$ & & & Other data & No numeric data \\
\hline 2 co-operation during induction & 1 & 58 & Risk Ratio (M-H, Random, 95\% CI) & $1.88[0.61,5.72]$ \\
\hline 2.1 poor compliance: ICC > 6 & 1 & 58 & Risk Ratio (M-H, Random, 95\% CI) & $1.88[0.61,5.72]$ \\
\hline 3 parental anxiety after leaving OR & 1 & 58 & Mean Difference (IV, Fixed, 95\% CI) & $-8.90[-15.23,-2.57]$ \\
\hline 3.1 STAI & 1 & 58 & Mean Difference (IV, Fixed, 95\% CI) & $-8.90[-15.23,-2.57]$ \\
\hline
\end{tabular}

Non-pharmacological interventions for assisting the induction of anaesthesia in children (Review) 


\begin{tabular}{|c|c|c|c|c|}
\hline Outcome or subgroup title & $\begin{array}{l}\text { No. of } \\
\text { studies }\end{array}$ & $\begin{array}{c}\text { No. of } \\
\text { participants }\end{array}$ & Statistical method & Effect size \\
\hline 1 anxiety during induction & 1 & & Mean Difference (IV, Fixed, 95\% CI) & Subtotals only \\
\hline $1.1 \mathrm{mYPAS}$ & 1 & 192 & Mean Difference (IV, Fixed, 95\% CI) & $10.0[2.91,17.09]$ \\
\hline 2 anxiety during induction & & & Other data & No numeric data \\
\hline 2.1 entrance to OR & & & Other data & No numeric data \\
\hline 2.2 introduction of mask & & & Other data & No numeric data \\
\hline 3 cooperation during induction & 1 & & Risk Ratio (M-H, Fixed, 95\% CI) & Subtotals only \\
\hline 3.1 poor compliance; ICC > 6 & 1 & 62 & Risk Ratio (M-H, Fixed, 95\% CI) & $12.47[0.72,216.20]$ \\
\hline 4 cooperation during induction & & & Other data & No numeric data \\
\hline $\begin{array}{l}4.1 \text { quality of mask induction } \\
\text { (out of } 3 ; 3 \text { worst) }\end{array}$ & & & Other data & No numeric data \\
\hline 5 parental anxiety & 1 & & Mean Difference (IV, Fixed, 95\% CI) & Subtotals only \\
\hline 5.1 STAI & 1 & 62 & Mean Difference (IV, Fixed, 95\% CI) & $4.0[-1.48,9.48]$ \\
\hline $\begin{array}{l}6 \text { time taken for induction } \\
\text { (minutes) }\end{array}$ & 1 & 62 & Mean Difference (IV, Fixed, 95\% CI) & $0.60[0.36,0.84]$ \\
\hline 7 emergence delirium & 1 & 192 & Risk Ratio (M-H, Fixed, 95\% CI) & $0.74[0.41,1.36]$ \\
\hline 8 emergence delirium & & & Other data & No numeric data \\
\hline $\begin{array}{l}8.1 \text { postoperative excitement } \\
\text { score }\end{array}$ & & & Other data & No numeric data \\
\hline $\begin{array}{l}8.2 \text { emergence behaviour (out } \\
\text { of } 5 ; 5 \text { worst) }\end{array}$ & & & Other data & No numeric data \\
\hline 9 negative behaviour postop & 1 & 62 & Risk Ratio (M-H, Fixed, 95\% CI) & $0.91[0.51,1.61]$ \\
\hline 9.12 weeks postop & 1 & 62 & Risk Ratio (M-H, Fixed, 95\% CI) & $0.91[0.51,1.61]$ \\
\hline 10 parental satisfaction & 1 & & Risk Ratio (M-H, Fixed, 95\% CI) & Subtotals only \\
\hline 10.1 overall & 1 & 62 & Risk Ratio (M-H, Fixed, 95\% CI) & $0.96[0.88,1.06]$ \\
\hline 10.2 anaesthetists & 1 & 62 & Risk Ratio (M-H, Fixed, 95\% CI) & $0.90[0.78,1.03]$ \\
\hline 10.3 nursing staff & 1 & 62 & Risk Ratio (M-H, Fixed, 95\% CI) & $1.0[0.94,1.06]$ \\
\hline
\end{tabular}

Comparison 4. Parental presence + midazolam versus no parental presence

\begin{tabular}{|c|c|c|c|c|}
\hline Outcome or subgroup title & $\begin{array}{l}\text { No. of } \\
\text { studies }\end{array}$ & $\begin{array}{c}\text { No. of } \\
\text { participants }\end{array}$ & Statistical method & Effect size \\
\hline 1 parental anxiety & 1 & & Mean Difference (IV, Fixed, 95\% CI) & Subtotals only \\
\hline $\begin{array}{l}1.1 \text { systolic blood pressure } \\
(\mathrm{mmHg})\end{array}$ & 1 & 51 & Mean Difference (IV, Fixed, 95\% CI) & $2.0[-7.71,11.71]$ \\
\hline $\begin{array}{l}1.2 \text { diastolic blood pressure } \\
(\mathrm{mmHg})\end{array}$ & 1 & 51 & Mean Difference (IV, Fixed, 95\% CI) & $4.0[-3.75,11.75]$ \\
\hline 2 parental anxiety & 1 & & Risk Ratio (M-H, Fixed, 95\% CI) & Subtotals only \\
\hline 2.1 isolated ventricular ectopy & 1 & 51 & Risk Ratio (M-H, Fixed, 95\% CI) & $0.89[0.20,4.00]$ \\
\hline $\begin{array}{l}2.2 \text { single premature atrial } \\
\text { contractions }\end{array}$ & 1 & 51 & Risk Ratio (M-H, Fixed, 95\% CI) & $0.59[0.11,3.25]$ \\
\hline
\end{tabular}

Non-pharmacological interventions for assisting the induction of anaesthesia in children (Review) 


\begin{tabular}{|c|c|c|c|c|}
\hline Outcome or subgroup title & $\begin{array}{l}\text { No. of } \\
\text { studies }\end{array}$ & $\begin{array}{c}\text { No. of } \\
\text { participants }\end{array}$ & Statistical method & Effect size \\
\hline 1 co-operation & 1 & 120 & Risk Ratio (M-H, Fixed, 95\% CI) & $1.30[0.87,1.96]$ \\
\hline $\begin{array}{l}1.1 \mathrm{ICC}=0 \text { (perfect vs } \\
\text { poor-moderate compliance) }\end{array}$ & 1 & 120 & Risk Ratio (M-H, Fixed, 95\% CI) & $1.30[0.87,1.96]$ \\
\hline 2 parental anxiety (STAI $\geq 46)$ & 1 & & Risk Ratio (M-H, Fixed, 95\% CI) & Subtotals only \\
\hline 2.1 in holding bay & 1 & 120 & Risk Ratio (M-H, Fixed, 95\% CI) & $0.55[0.30,1.00]$ \\
\hline $\begin{array}{l}2.2 \text { after leaving operating } \\
\text { theatre }\end{array}$ & 1 & 120 & Risk Ratio (M-H, Fixed, 95\% CI) & $1.0[0.70,1.43]$ \\
\hline 3 parental anxiety (APAIS $\geq 13$ ) & 1 & & Risk Ratio (M-H, Fixed, 95\% CI) & Subtotals only \\
\hline 3.1 in holding bay & 1 & 120 & Risk Ratio (M-H, Fixed, 95\% CI) & $0.52[0.28,0.99]$ \\
\hline $\begin{array}{l}3.2 \text { after leaving operating } \\
\text { theatre }\end{array}$ & 1 & 120 & Risk Ratio (M-H, Fixed, 95\% CI) & $0.46[0.26,0.83]$ \\
\hline 4 parental anxiety (STAI) & 1 & & Mean Difference (IV, Fixed, 95\% CI) & Subtotals only \\
\hline 4.1 STATE: in holding area & 1 & 120 & Mean Difference (IV, Fixed, 95\% CI) & $-5.30[-9.04,-1.56]$ \\
\hline $\begin{array}{l}\text { 4.2 STATE: after leaving } \\
\text { operating theatre }\end{array}$ & 1 & 120 & Mean Difference (IV, Fixed, 95\% CI) & $-5.0[-9.51,-0.49]$ \\
\hline 5 parental anxiety (APAIS) & 1 & & Mean Difference (IV, Fixed, 95\% CI) & Subtotals only \\
\hline 5.1 STATE: in holding area & 1 & 120 & Mean Difference (IV, Fixed, 95\% CI) & $-1.70[-3.02,-0.38]$ \\
\hline $\begin{array}{l}5.2 \text { STATE: after leaving } \\
\text { operating theatre }\end{array}$ & 1 & 120 & Mean Difference (IV, Fixed, 95\% CI) & $-2.0[-3.39,-0.61]$ \\
\hline $\begin{array}{l}5.3 \text { INFORMATION: in } \\
\text { holding area }\end{array}$ & 1 & 120 & Mean Difference (IV, Fixed, 95\% CI) & $0.10[-0.53,0.73]$ \\
\hline $\begin{array}{l}5.4 \text { INFORMATION: after } \\
\text { leaving operating theatre }\end{array}$ & 1 & 120 & Mean Difference (IV, Fixed, 95\% CI) & $0.0[-0.76,0.76]$ \\
\hline
\end{tabular}

Comparison 6. Low sensory stimulation versus control

\begin{tabular}{lccll} 
Outcome or subgroup title & $\begin{array}{c}\text { No. of } \\
\text { studies }\end{array}$ & $\begin{array}{c}\text { No. of } \\
\text { participants }\end{array}$ & \multicolumn{1}{c}{ Statistical method } & \multicolumn{1}{c}{ Effect size } \\
\hline $\begin{array}{l}1 \text { co-operation at induction } \\
\text { 1.1 ICC }=0\end{array}$ & 1 & & Risk Ratio (M-H, Fixed, 95\% CI) & Subtotals only \\
$\begin{array}{l}2 \text { parental anxiety } \\
\text { 2.1 STAI }\end{array}$ & 1 & 70 & $\begin{array}{l}\text { Risk Ratio (M-H, Fixed, 95\% CI) } \\
\text { Mean Difference (IV, Fixed, 95\% CI) }\end{array}$ & $\begin{array}{l}\text { Subtotals only } \\
\text { STI }\end{array}$ \\
\hline
\end{tabular}




\begin{tabular}{|c|c|c|c|c|}
\hline Outcome or subgroup title & $\begin{array}{l}\text { No. of } \\
\text { studies }\end{array}$ & $\begin{array}{c}\text { No. of } \\
\text { participants }\end{array}$ & Statistical method & Effect size \\
\hline 1 anxiety & 1 & & Risk Ratio (M-H, Fixed, 95\% CI) & Subtotals only \\
\hline $\begin{array}{l}1.1 \text { post intervention } \\
\text { (introduction of mask) }\end{array}$ & 1 & 103 & Risk Ratio (M-H, Fixed, 95\% CI) & $6.44[0.78,53.23]$ \\
\hline 1.2 at induction of anaesthesia & 1 & 103 & Risk Ratio (M-H, Fixed, 95\% CI) & $0.59[0.31,1.11]$ \\
\hline $\begin{array}{l}2 \text { co-operation (ICC): number of } \\
\text { children compliant }\end{array}$ & 1 & 102 & Risk Ratio (M-H, Fixed, 95\% CI) & $1.27[1.06,1.51]$ \\
\hline 3 parental anxiety (STAI: trait) & 1 & 102 & Mean Difference (IV, Fixed, 95\% CI) & $-1.06[-3.35,1.23]$ \\
\hline
\end{tabular}

Comparison 8. Computer preparation versus control

\begin{tabular}{|c|c|c|c|}
\hline Outcome or subgroup title & $\begin{array}{lc}\text { No. of } & \text { No. of } \\
\text { studies } & \text { participants }\end{array}$ & Statistical method & Effect size \\
\hline 1 co-operation during induction & & Other data & No numeric data \\
\hline 1.1 coping VAS & & Other data & No numeric data \\
\hline 2 negative behavioural changes & & Other data & No numeric data \\
\hline 2.1 coping VAS & & Other data & No numeric data \\
\hline
\end{tabular}

Comparison 9. Cartoon preparation versus control

\begin{tabular}{|c|c|c|c|}
\hline Outcome or subgroup title & $\begin{array}{lc}\text { No. of } & \text { No. of } \\
\text { studies } & \text { participants }\end{array}$ & Statistical method & Effect size \\
\hline 1 co-operation during induction & & Other data & No numeric data \\
\hline 1.1 coping VAS & & Other data & No numeric data \\
\hline 2 negative behavioural changes & & Other data & No numeric data \\
\hline 2.1 coping VAS & & Other data & No numeric data \\
\hline
\end{tabular}

\section{Comparison 10. Computer versus cartoon preparation}

\begin{tabular}{|c|c|c|c|}
\hline Outcome or subgroup title & $\begin{array}{lc}\text { No. of } & \text { No. of } \\
\text { studies } & \text { participants }\end{array}$ & Statistical method & Effect size \\
\hline 1 co-operation during induction & & Other data & No numeric data \\
\hline 1.1 coping VAS $(0-10)$ & & Other data & No numeric data \\
\hline 2 negative behavioural change & & Other data & No numeric data \\
\hline 2.1 coping VAS $(0-10)$ & & Other data & No numeric data \\
\hline
\end{tabular}




\begin{tabular}{ccccc} 
Outcome or subgroup title & $\begin{array}{c}\text { No. of } \\
\text { studies }\end{array}$ & $\begin{array}{c}\text { No. of } \\
\text { participants }\end{array}$ & Statistical method & Effect size \\
\hline $\begin{array}{c}1 \text { anxiety during induction } \\
1.1 \text { mYPAS }\end{array}$ & 1 & & Mean Difference (IV, Fixed, 95\% CI) & Subtotals only \\
2 negative behaviour postop & 1 & 74 & $\begin{array}{l}\text { Mean Difference (IV, Fixed, 95\% CI) } \\
\text { Mean Difference (IV, Fixed, 95\% CI) }\end{array}$ & $\begin{array}{l}-9.80[-19.42,-0.18] \\
\text { Subtotals only }\end{array}$ \\
2.1 PHBQ & 1 & 74 & Mean Difference (IV, Fixed, 95\% CI) & $0.40[-1.72,2.52]$ \\
\hline
\end{tabular}

\section{Comparison 12. Video game versus midazolam}

\begin{tabular}{|c|c|c|c|c|}
\hline Outcome or subgroup title & $\begin{array}{l}\text { No. of } \\
\text { studies }\end{array}$ & $\begin{array}{c}\text { No. of } \\
\text { participants }\end{array}$ & Statistical method & Effect size \\
\hline 1 anxiety during induction & 1 & & Mean Difference (IV, Fixed, 95\% CI) & Subtotals only \\
\hline $1.1 \mathrm{mYPAS}$ & 1 & 76 & Mean Difference (IV, Fixed, 95\% CI) & $\begin{array}{l}-12.20[-21.82,-2 . \\
58]\end{array}$ \\
\hline 2 negative behaviour postop & 1 & & Mean Difference (IV, Fixed, 95\% CI) & Subtotals only \\
\hline 2.1 PHBQ & 1 & 76 & Mean Difference (IV, Fixed, 95\% CI) & $-0.5[-2.60,1.60]$ \\
\hline
\end{tabular}

\section{Comparison 13. Clowns/clown doctors versus parental presence}

\begin{tabular}{|c|c|c|c|c|}
\hline Outcome or subgroup title & $\begin{array}{l}\text { No. of } \\
\text { studies }\end{array}$ & $\begin{array}{c}\text { No. of } \\
\text { participants }\end{array}$ & Statistical method & Effect size \\
\hline 1 anxiety & 5 & & Mean Difference (IV, Random, 95\% CI) & Subtotals only \\
\hline $\begin{array}{l}1.1 \mathrm{mYPAS} \text { in } \\
\text { operating/induction room }\end{array}$ & 3 & 133 & Mean Difference (IV, Random, 95\% CI) & $\begin{array}{l}-24.41[-38.34,-10 . \\
48]\end{array}$ \\
\hline $\begin{array}{l}1.2 \text { mYPAS at application of } \\
\text { mask }\end{array}$ & 1 & 43 & Mean Difference (IV, Random, 95\% CI) & $8.30[-2.68,19.28]$ \\
\hline 1.3 CSWQ - hospitalisation & 1 & 70 & Mean Difference (IV, Random, 95\% CI) & $-1.1[-1.37,-0.83]$ \\
\hline $\begin{array}{l}1.4 \text { CSWQ - medical } \\
\text { procedures }\end{array}$ & 1 & 70 & Mean Difference (IV, Random, 95\% CI) & $-1.25[-1.64,-0.86]$ \\
\hline $\begin{array}{l}1.5 \text { CSWQ - illness and } \\
\text { consequences }\end{array}$ & 1 & 70 & Mean Difference (IV, Random, 95\% CI) & $-1.57[-1.93,-1.21]$ \\
\hline 1.6 FAS & 1 & 61 & Mean Difference (IV, Random, 95\% CI) & $0.06[-0.09,0.21]$ \\
\hline 2 co-operation at induction & 1 & & Mean Difference (IV, Random, 95\% CI) & Subtotals only \\
\hline 2.1 SAM - affective valence & 1 & 70 & Mean Difference (IV, Random, 95\% CI) & $2.08[1.42,2.74]$ \\
\hline 2.2 SAM - arousal & 1 & 70 & Mean Difference (IV, Random, 95\% CI) & $-1.70[-2.33,-1.07]$ \\
\hline 3 parental anxiety & 3 & & Mean Difference (IV, Fixed, 95\% CI) & Subtotals only \\
\hline 3.1 STAI - Y & 1 & 105 & Mean Difference (IV, Fixed, 95\% CI) & $-4.75[-14.69,5.19]$ \\
\hline 3.2 STAI (state) & 2 & 120 & Mean Difference (IV, Fixed, 95\% CI) & $-0.34[-0.54,-0.14]$ \\
\hline 3.3 STAI (trait) & 1 & 50 & Mean Difference (IV, Fixed, 95\% CI) & $-4.84[-9.97,0.29]$ \\
\hline 4 negative behaviour postop & 1 & 61 & Mean Difference (IV, Random, 95\% CI) & $-6.30[-12.58,-0.02]$ \\
\hline 4.1 PHBQ & 1 & 61 & Mean Difference (IV, Random, 95\% CI) & $-6.30[-12.58,-0.02]$ \\
\hline
\end{tabular}




\begin{tabular}{lcclc} 
Outcome or subgroup title & $\begin{array}{c}\text { No. of } \\
\text { studies }\end{array}$ & $\begin{array}{c}\text { No. of } \\
\text { participants }\end{array}$ & Statistical method & Effect size \\
\hline $\begin{array}{l}\text { 1 anxiety } \\
1.1 \text { mYPAS in operating room }\end{array}$ & 2 & & Mean Difference (IV, Random, 95\% CI) & Subtotals only \\
$\begin{array}{l}1.2 \text { mYPAS at application of } \\
\text { mask }\end{array}$ & 1 & 43 & Mean Difference (IV, Random, 95\% CI) & $-9.67[-21.14,1.80]$ \\
$\begin{array}{l}\text { 2 parental anxiety } \\
\text { 2.1 STAI (state) }\end{array}$ & 1 & & Mean Difference (IV, Fixed, 95\% CI) & Subtotals only \\
2.2 STAI (trait) & 1 & 50 & Mean Difference (IV, Fixed, 95\% CI) & $21.12[13.95,28.29]$ \\
\hline
\end{tabular}

Comparison 15. Hypnosis versus midazolam

\begin{tabular}{|c|c|c|c|c|}
\hline Outcome or subgroup title & $\begin{array}{l}\text { No. of } \\
\text { studies }\end{array}$ & $\begin{array}{c}\text { No. of } \\
\text { participants }\end{array}$ & Statistical method & Effect size \\
\hline 1 anxiety during induction & 1 & & Risk Ratio (M-H, Fixed, 95\% CI) & Subtotals only \\
\hline 1.1 mYPAS $<24$ & 1 & 50 & Risk Ratio (M-H, Fixed, 95\% CI) & $0.59[0.33,1.04]$ \\
\hline 2 negative behaviour postop & 1 & & Risk Ratio (M-H, Fixed, 95\% CI) & Subtotals only \\
\hline 2.1 PHBQ day 1 & 1 & 50 & Risk Ratio (M-H, Fixed, 95\% CI) & $0.48[0.24,0.96]$ \\
\hline 2.2 PHBQ day 7 & 1 & 50 & Risk Ratio (M-H, Fixed, 95\% CI) & $0.44[0.21,0.94]$ \\
\hline
\end{tabular}

\section{Comparison 16. Acupuncture for parents}

\begin{tabular}{|c|c|c|c|c|}
\hline Outcome or subgroup title & $\begin{array}{l}\text { No. of } \\
\text { studies }\end{array}$ & $\begin{array}{c}\text { No. of } \\
\text { participants }\end{array}$ & Statistical method & Effect size \\
\hline 1 anxiety during induction & 1 & & Mean Difference (IV, Fixed, 95\% CI) & Subtotals only \\
\hline $1.1 \mathrm{mYPAS}$ & 1 & 67 & Mean Difference (IV, Fixed, 95\% CI) & $-17.0[-30.51,-3.49]$ \\
\hline 2 co-operation during induction & 1 & & Risk Ratio (M-H, Fixed, 95\% CI) & Subtotals only \\
\hline 2.1 perfect induction $\mathrm{ICC}=0$ & 1 & 67 & Risk Ratio (M-H, Fixed, 95\% CI) & $1.59[1.01,2.53]$ \\
\hline 3 parental anxiety & 1 & & Mean Difference (IV, Fixed, 95\% CI) & Subtotals only \\
\hline 3.1 STAI (acupuncture) & 1 & 67 & Mean Difference (IV, Fixed, 95\% CI) & $-6.60[-11.64,-1.56]$ \\
\hline 3.2 STAI (acupressure) & 0 & 0 & Mean Difference (IV, Fixed, 95\% CI) & $0.0[0.0,0.0]$ \\
\hline 3.3 heart rate & 1 & 67 & Mean Difference (IV, Fixed, 95\% CI) & $0.5[-4.77,5.77]$ \\
\hline $\begin{array}{l}3.4 \text { systolic blood pressure } \\
(\mathrm{mmHg})\end{array}$ & 1 & 67 & Mean Difference (IV, Fixed, 95\% CI) & $0.0[-7.04,7.04]$ \\
\hline $\begin{array}{l}3.5 \text { diastolic blood pressure } \\
(\mathrm{mmHg})\end{array}$ & 1 & 67 & Mean Difference (IV, Fixed, 95\% CI) & $0.0[-4.81,4.81]$ \\
\hline
\end{tabular}

Non-pharmacological interventions for assisting the induction of anaesthesia in children (Review) 


\begin{tabular}{|c|c|c|c|c|}
\hline Outcome or subgroup title & $\begin{array}{l}\text { No. of } \\
\text { studies }\end{array}$ & $\begin{array}{c}\text { No. of } \\
\text { participants }\end{array}$ & Statistical method & Effect size \\
\hline 1 parental anxiety & 2 & & Mean Difference (IV, Fixed, 95\% CI) & Subtotals only \\
\hline 1.1 STAI & 1 & 80 & Mean Difference (IV, Fixed, 95\% CI) & $1.0[-1.88,3.88]$ \\
\hline 1.2 APAIS anxiety score & 1 & 111 & Mean Difference (IV, Fixed, 95\% CI) & $-0.06[-1.40,1.28]$ \\
\hline $\begin{array}{l}1.3 \text { mean arterial blood } \\
\text { pressure }(\mathrm{mmHg})\end{array}$ & 1 & 80 & Mean Difference (IV, Fixed, 95\% CI) & $-4.0[-7.27,-0.73]$ \\
\hline 1.4 heart rate & 1 & 80 & Mean Difference (IV, Fixed, 95\% CI) & $-3.0[-7.37,1.37]$ \\
\hline $\begin{array}{l}\text { 1.5 APAIS desire for } \\
\text { information score }\end{array}$ & 1 & 111 & Mean Difference (IV, Fixed, 95\% CI) & $-0.82[-1.64,-0.00]$ \\
\hline 1.6 APAIS total score & 1 & 111 & Mean Difference (IV, Fixed, 95\% CI) & $-0.89[-2.74,0.96]$ \\
\hline
\end{tabular}

\section{Analysis I.I. Comparison I Parental presence versus no parental presence, Outcome I anxiety during induction.}

Review: Non-pharmacological interventions for assisting the induction of anaesthesia in children

Comparison: I Parental presence versus no parental presence

Outcome: I anxiety during induction

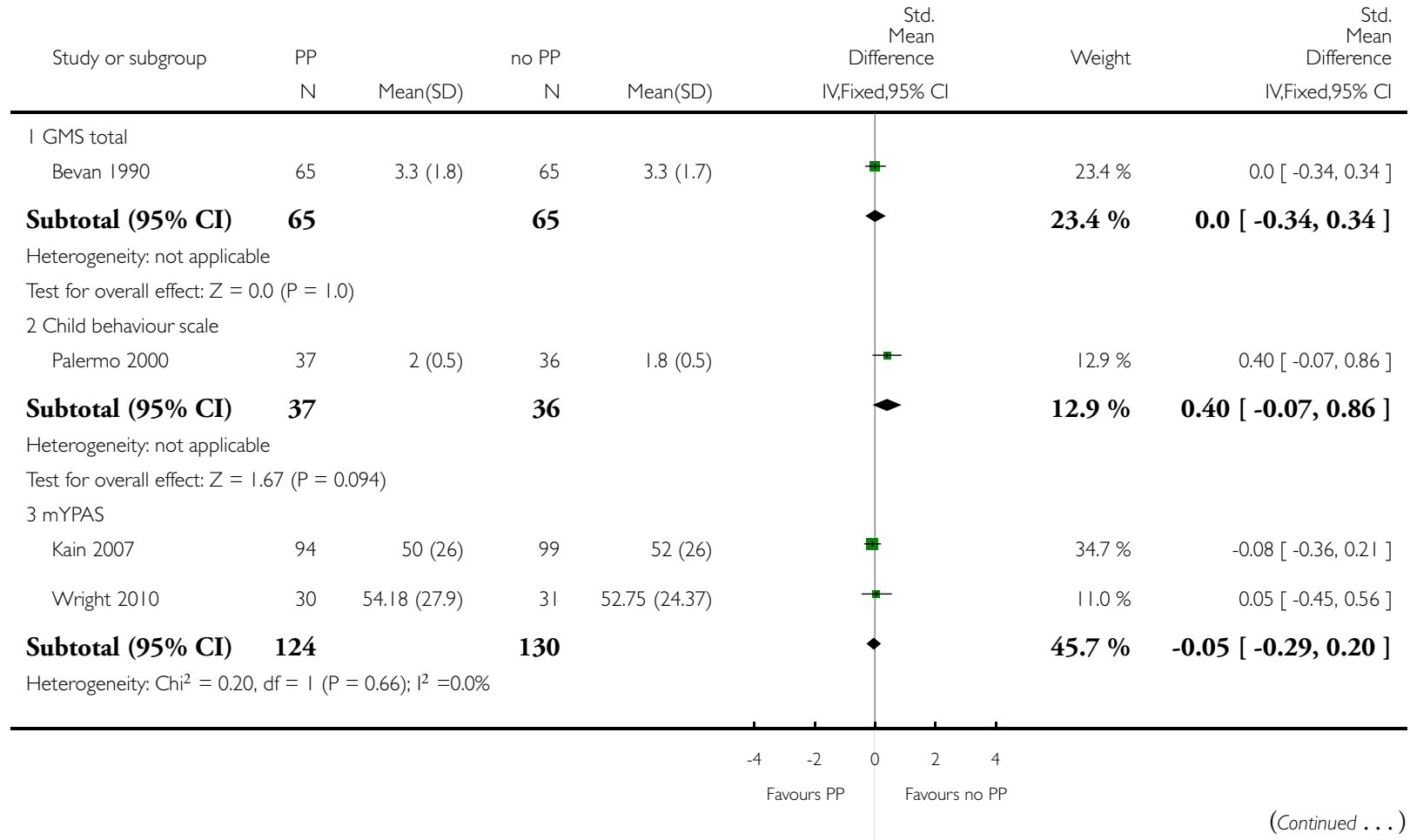

Non-pharmacological interventions for assisting the induction of anaesthesia in children (Review) 


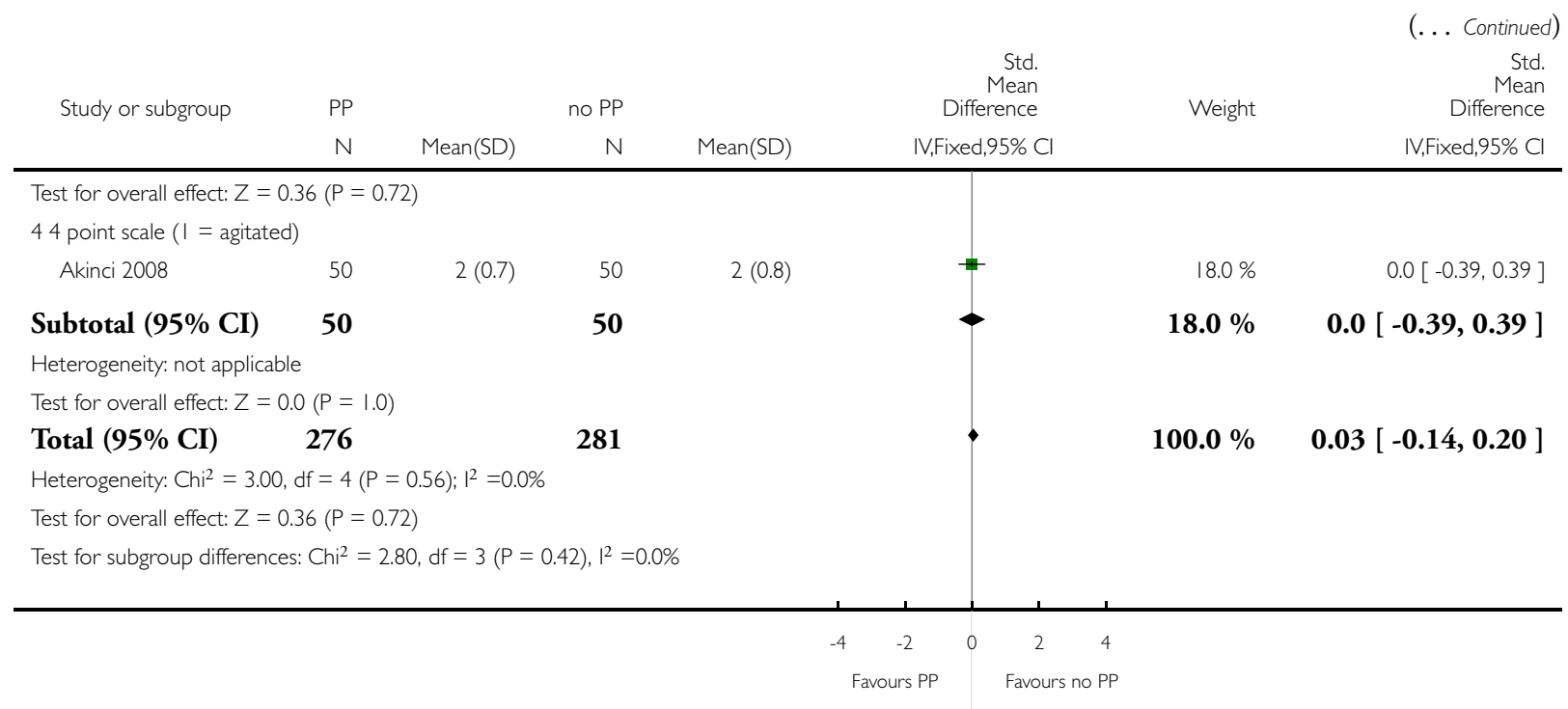

Analysis I.2. Comparison I Parental presence versus no parental presence, Outcome 2 anxiety during induction.

anxiety during induction

\begin{tabular}{|c|c|c|c|}
\hline Study & PP (median, range) & No PP (median, range) & $p$ value $(n=103)$ \\
\hline \multicolumn{4}{|l|}{ VAS } \\
\hline Kain 1996b & $\begin{array}{l}\text { VAS } 45(8-86) \\
\text { YPAS } 42(30-62) \\
\text { CARS } 1(0-4)\end{array}$ & $\begin{array}{l}43(5-78) \\
38(24-65) \\
1(0-4)\end{array}$ & $\begin{array}{l}\text { ns } \\
\text { ns } \\
\text { ns }\end{array}$ \\
\hline \multicolumn{4}{|l|}{ mYPAS } \\
\hline Kain 2000 & not reported & not reported & 0.49 \\
\hline \multicolumn{4}{|c|}{ serum cortisol $(\mathrm{mcg} / \mathrm{ml})$} \\
\hline Kain 1996b & $76(48-91)$ & $73(51-100)$ & ns \\
\hline
\end{tabular}


Analysis I.3. Comparison I Parental presence versus no parental presence, Outcome 3 anxiety during induction (parental anxiety subgroup).

Review: Non-pharmacological interventions for assisting the induction of anaesthesia in children

Comparison: I Parental presence versus no parental presence

Outcome: 3 anxiety during induction (parental anxiety subgroup)

\begin{tabular}{|c|c|c|c|c|c|c|c|c|c|}
\hline \multirow[t]{2}{*}{ Study or subgroup } & PP & \multicolumn{3}{|c|}{ Control } & \multicolumn{3}{|c|}{$\begin{array}{r}\text { Mean } \\
\text { Difference }\end{array}$} & \multirow[t]{2}{*}{ Weight } & \multirow{2}{*}{$\begin{array}{r}\text { Mean } \\
\text { Difference } \\
\text { IV,Fixed,95\% Cl }\end{array}$} \\
\hline & $\mathrm{N}$ & Mean(SD) & $N$ & Mean(SD) & & & ed,95\% Cl & & \\
\hline \multicolumn{10}{|l|}{ I GMS anxious parent } \\
\hline Bevan 1990 & 24 & $4.5(1.5)$ & 25 & $3.4(1.5)$ & & & & $100.0 \%$ & $1.10[0.26,1.94]$ \\
\hline Subtotal (95\% CI) & 24 & & 25 & & & & $\bullet$ & $100.0 \%$ & $1.10[0.26,1.94]$ \\
\hline \multicolumn{10}{|c|}{ Heterogeneity: not applicable } \\
\hline \multicolumn{10}{|c|}{ Test for overall effect: $Z=2.57(P=0.010)$} \\
\hline \multicolumn{10}{|l|}{2 GMS calm parent } \\
\hline Bevan 1990 & 30 & $3.4(1.6)$ & 33 & $3.5(1.8)$ & & & & $100.0 \%$ & $-0.10[-0.94,0.74]$ \\
\hline Subtotal (95\% CI) & 30 & & 33 & & & & P & $100.0 \%$ & $-0.10[-0.94,0.74]$ \\
\hline \multicolumn{10}{|c|}{ Heterogeneity: not applicable } \\
\hline \multicolumn{10}{|c|}{ Test for overall effect: $Z=0.23(P=0.82)$} \\
\hline \multicolumn{10}{|c|}{ Test for subgroup differences: $\mathrm{Chi}^{2}=3.92, \mathrm{df}=\mathrm{I}(\mathrm{P}=0.05), \mathrm{I}^{2}=74 \%$} \\
\hline & & & & & -10 & -5 & 5 & 10 & \\
\hline & & & & Favours & ental & eser & Favou & parental pres & \\
\hline
\end{tabular}

Analysis I.4. Comparison I Parental presence versus no parental presence, Outcome 4 cooperation during induction.

cooperation during induction

\begin{tabular}{|c|c|c|c|}
\hline Study & PP + midazolam (median, range) & Midazolam (median, range) & P value \\
\hline \multicolumn{4}{|l|}{ VAS } \\
\hline Kain $1996 b$ & $89,73-92(n=43)$ & $85,67-91(n=41)$ & ns \\
\hline \multicolumn{4}{|c|}{ ICC > 6 (poor) } \\
\hline Kain 2000 & $\begin{array}{l}11 \%(\text { overall } \mathrm{n}=103 \text {; breakdown not } \\
\text { reported) }\end{array}$ & $15 \%$ & ns \\
\hline \multicolumn{4}{|c|}{ Quality of mask induction (out of 3 - 3 worst) } \\
\hline Arai 2007 & $2(1-3)(n=19)$ & $2(1-3)(n=19)$ & ns \\
\hline
\end{tabular}


Analysis I.5. Comparison I Parental presence versus no parental presence, Outcome 5 anxiety/distress before induction.

Review: Non-pharmacological interventions for assisting the induction of anaesthesia in children

Comparison: I Parental presence versus no parental presence

Outcome: 5 anxiety/distress before induction

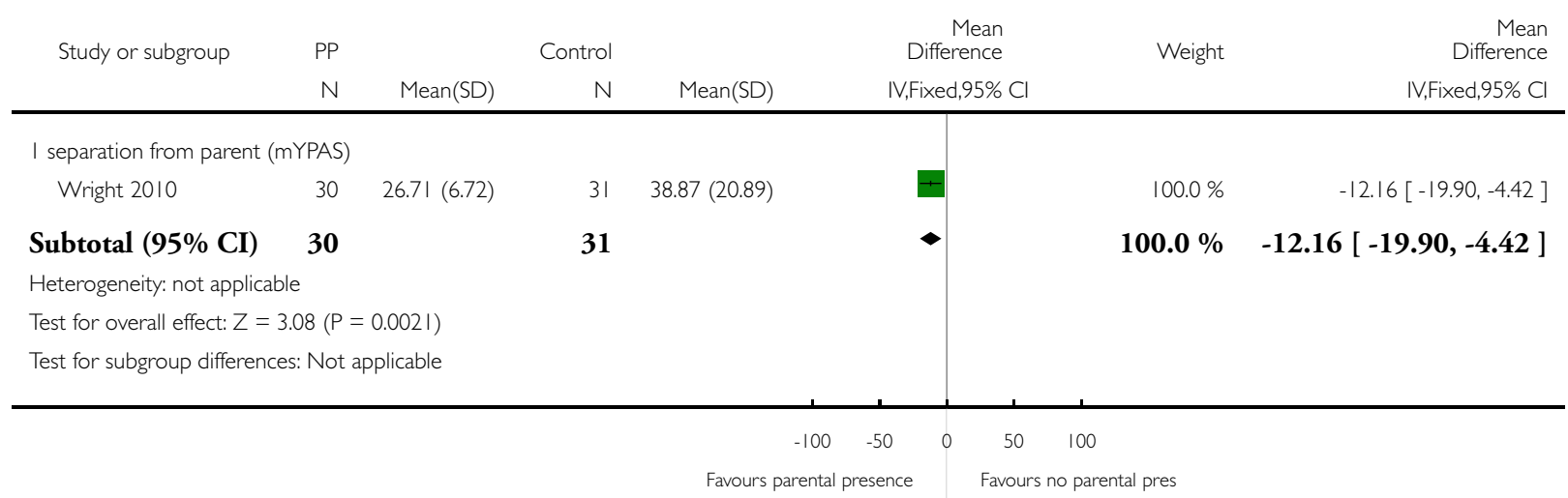


Analysis I.6. Comparison I Parental presence versus no parental presence, Outcome 6 parental anxiety (on day of surgery).

Review: Non-pharmacological interventions for assisting the induction of anaesthesia in children

Comparison: I Parental presence versus no parental presence

Outcome: 6 parental anxiety (on day of surgery)

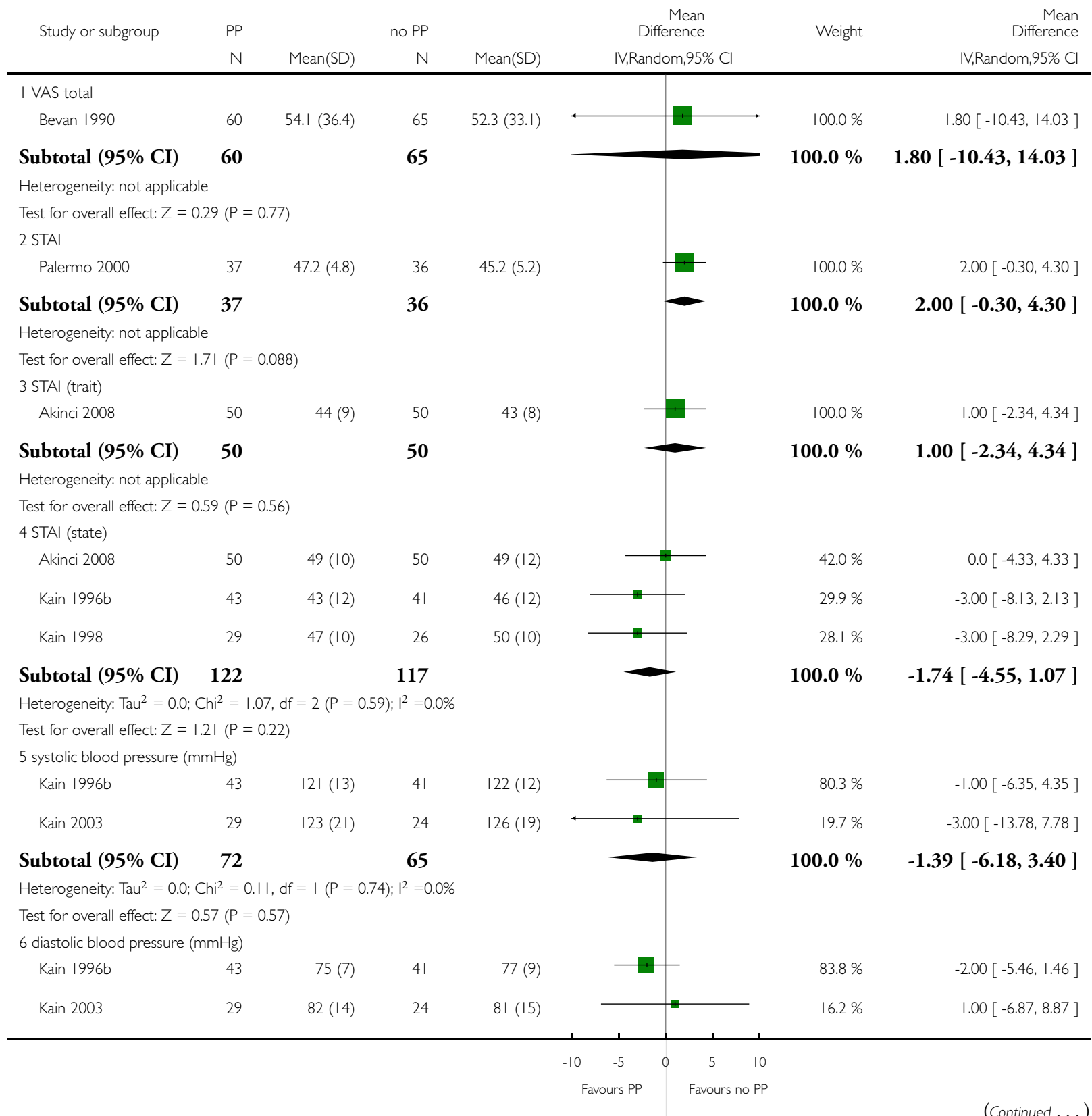

Non-pharmacological interventions for assisting the induction of anaesthesia in children (Review)

Copyright @ 2015 The Cochrane Collaboration. Published by John Wiley \& Sons, Ltd. 


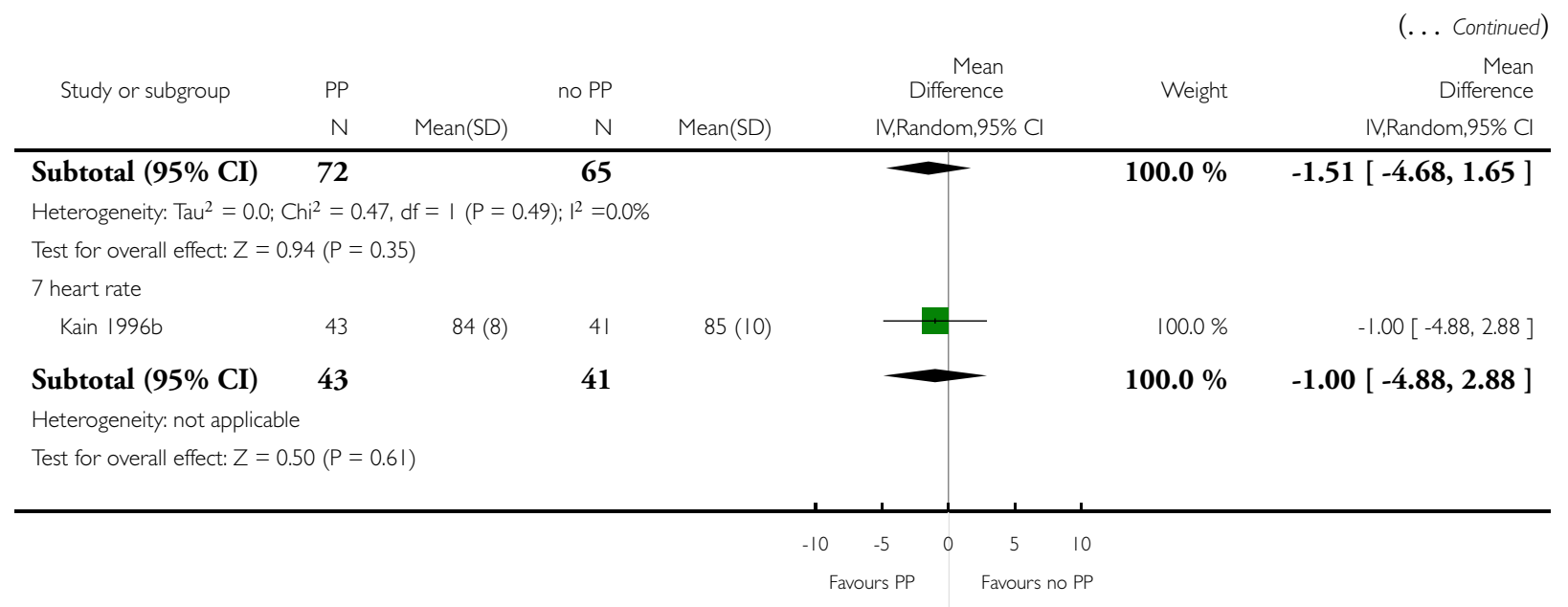

Analysis I.7. Comparison I Parental presence versus no parental presence, Outcome 7 parental anxiety (physiological signs).

Review: Non-pharmacological interventions for assisting the induction of anaesthesia in children

Comparison: I Parental presence versus no parental presence

Outcome: 7 parental anxiety (physiological signs)

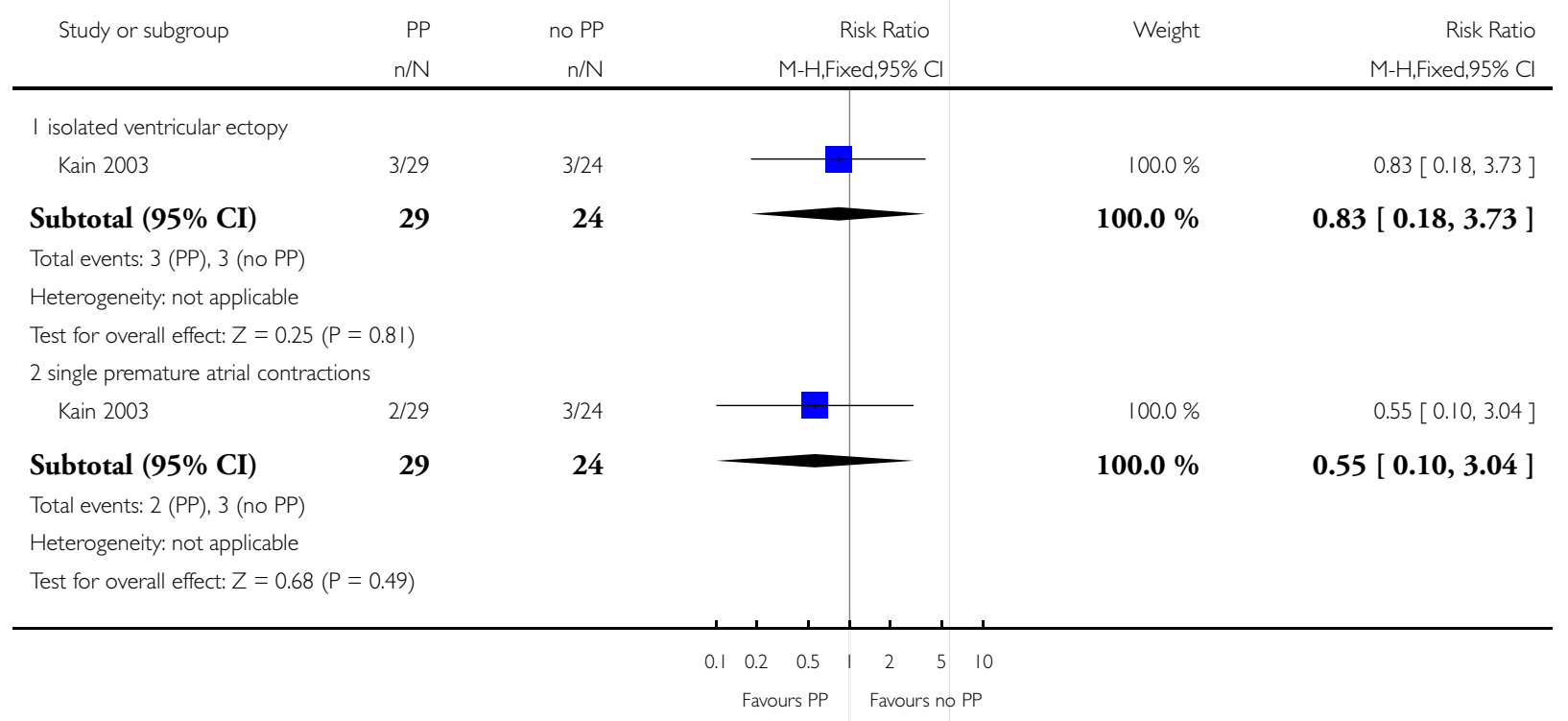


Analysis I.8. Comparison I Parental presence versus no parental presence, Outcome 8 parental anxiety during induction (parental anxiety subgroup).

Review: Non-pharmacological interventions for assisting the induction of anaesthesia in children

Comparison: I Parental presence versus no parental presence

Outcome: 8 parental anxiety during induction (parental anxiety subgroup)

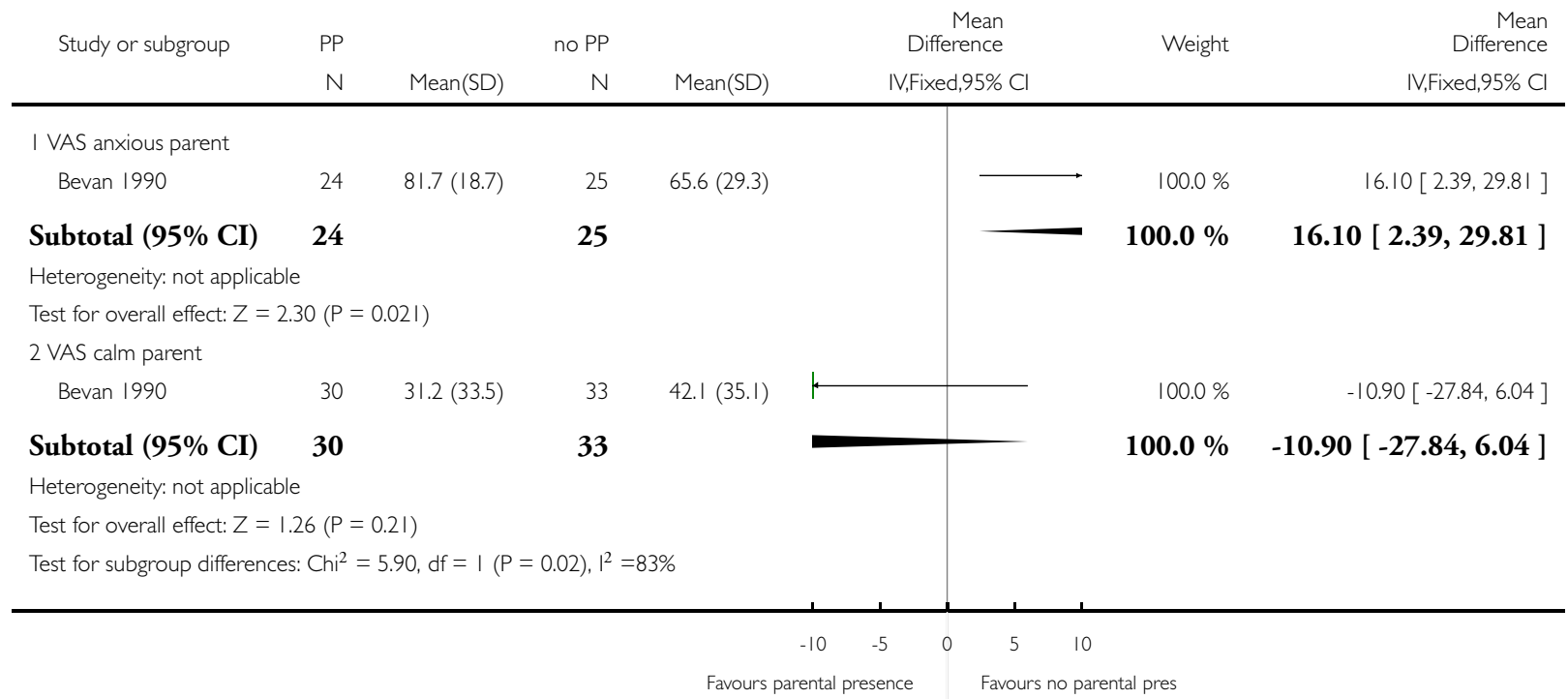


Analysis I.9. Comparison I Parental presence versus no parental presence, Outcome 9 parental anxiety postop.

Review: Non-pharmacological interventions for assisting the induction of anaesthesia in children

Comparison: I Parental presence versus no parental presence

Outcome: 9 parental anxiety postop

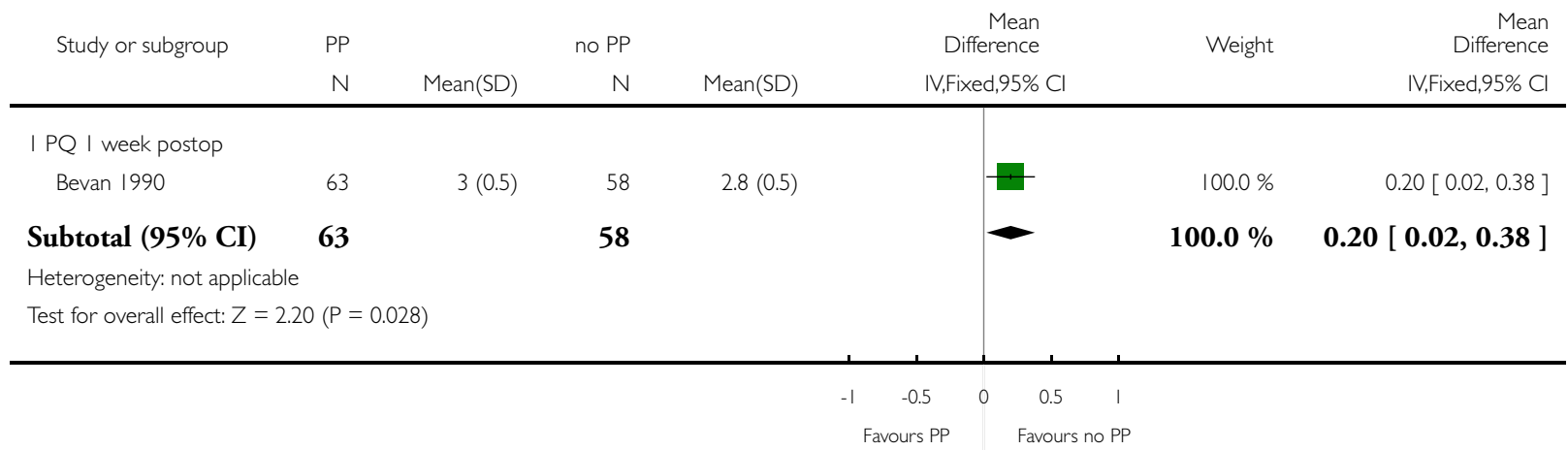

Analysis I.10. Comparison I Parental presence versus no parental presence, Outcome 10 parental anxiety. parental anxiety

\begin{tabular}{l|l|l|l}
\hline Study & Parental presence + midazolam & Midazolam & P value \\
\hline Kain 2000 & mean 43 [SD 11] & mean 48 [SD 12] & $P=0.037$ (controlling for parental anxiety at baseline) \\
\hline
\end{tabular}


Analysis I.II. Comparison I Parental presence versus no parental presence, Outcome I I emergence delirium.

Review: Non-pharmacological interventions for assisting the induction of anaesthesia in children

Comparison: I Parental presence versus no parental presence

Outcome: II emergence delirium

\begin{tabular}{|c|c|c|c|c|c|}
\hline \multirow[t]{2}{*}{ Study or subgroup } & PP & no PP & Risk Ratio & \multirow[t]{2}{*}{ Weight } & \multirow{2}{*}{$\begin{array}{r}\text { Risk Ratio } \\
\text { M-H,Fixed,95\% Cl }\end{array}$} \\
\hline & $n / N$ & $\mathrm{n} / \mathrm{N}$ & M-H,Fixed,95\% Cl & & \\
\hline Kain 2007 & $15 / 94$ & $24 / 99$ & & $100.0 \%$ & $0.66[0.37,1.18]$ \\
\hline Total (95\% CI) & 94 & 99 & & $100.0 \%$ & $0.66[0.37,1.18]$ \\
\hline \multicolumn{6}{|c|}{ Total events: I5 (PP), 24 (no PP) } \\
\hline \multicolumn{6}{|c|}{ Heterogeneity: not applicable } \\
\hline \multicolumn{6}{|c|}{ Test for overall effect: $Z=1.41(P=0.16)$} \\
\hline Test for subgroup diffe & t applic & & & & \\
\hline
\end{tabular}

$\begin{array}{lllllll}0.1 & 0.2 & 0.5 & 1 & 2 & 5 & 10\end{array}$

Favours PP Favours no PP

Analysis I.I2. Comparison I Parental presence versus no parental presence, Outcome I 2 emergence delirium.

emergence delirium

\begin{tabular}{l|lllll}
\hline Study & PP (median) & $\mathbf{P P}($ range) & no PP (median) & no PP (range) & P value \\
\hline postoperative excitement score & & & \\
\hline Kain 1998 & $1(\mathrm{n}=29)$ & $1-1.5$ & $1(\mathrm{n}=26)$ & $1-2$ & $\mathrm{~ns}$ \\
\hline Kain 2000 & $2(\mathrm{n}=19)$ & $1-2$ & $2(\mathrm{n}=19)$ & $1-3$ & 0.28 \\
\hline emergence behaviour (out of $5-\mathbf{5}$ worst) & & \\
\hline Arai 2007 & $3(\mathrm{n}=19)$ & $2-4$ & $4(\mathrm{n}=19)$ & $2-5$ & 0.05 \\
\hline
\end{tabular}


Analysis I.I3. Comparison I Parental presence versus no parental presence, Outcome I 3 time taken for induction (minutes).

Review: Non-pharmacological interventions for assisting the induction of anaesthesia in children

Comparison: I Parental presence versus no parental presence

Outcome: 13 time taken for induction (minutes)

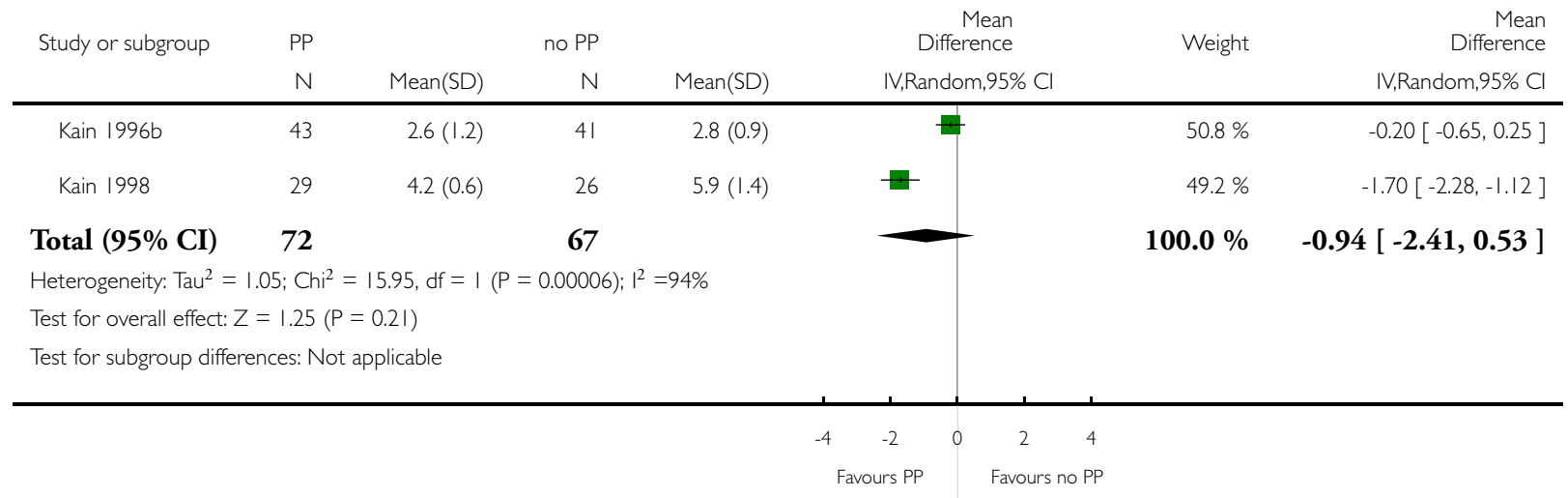




\section{Analysis I.14. Comparison I Parental presence versus no parental presence, Outcome I4 negative}

behaviour postop.

Review: Non-pharmacological interventions for assisting the induction of anaesthesia in children

Comparison: I Parental presence versus no parental presence

Outcome: 14 negative behaviour postop

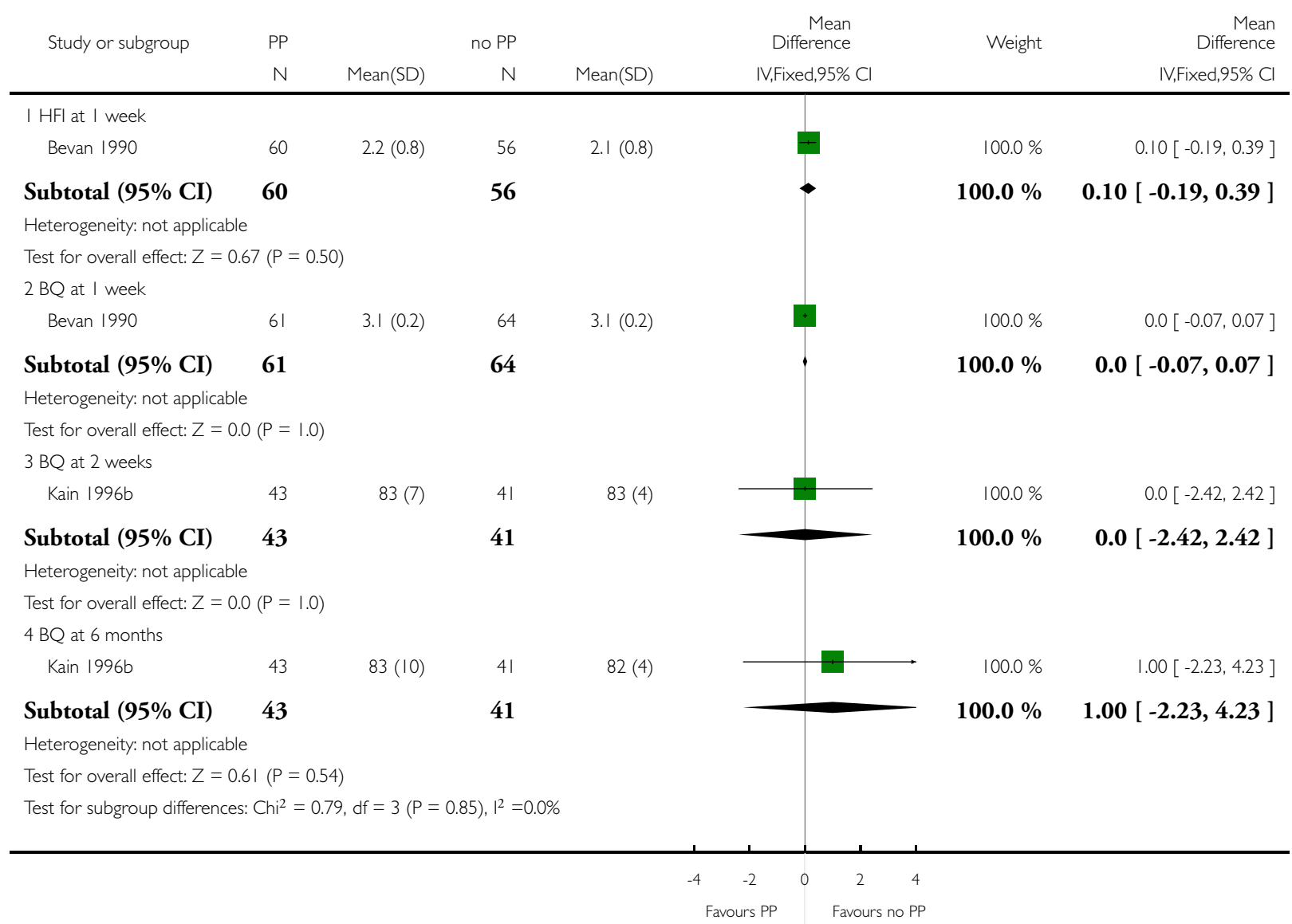




\section{Analysis I.15. Comparison I Parental presence versus no parental presence, Outcome I5 negative behaviour postop.}

\begin{tabular}{|c|c|c|c|c|c|}
\hline \multicolumn{6}{|c|}{ Comparison: I Parental presence versus no parental presence } \\
\hline \multicolumn{6}{|c|}{ Outcome: 15 negative behaviour postop } \\
\hline \multirow[t]{2}{*}{ Study or subgroup } & PP & no PP & Risk Ratio & Weight & Risk Ratio \\
\hline & $\mathrm{n} / \mathrm{N}$ & $\mathrm{n} / \mathrm{N}$ & M-H,Fixed,95\% Cl & & M-H,Fixed,95\% Cl \\
\hline \multicolumn{6}{|l|}{ I 2 weeks postop } \\
\hline Kain 1998 & $12 / 29$ & $11 / 26$ & & $100.0 \%$ & $0.98[0.52,1.83]$ \\
\hline Total $(95 \% \mathrm{CI})$ & 29 & 26 & - & $100.0 \%$ & $0.98[0.52,1.83]$ \\
\hline \multicolumn{6}{|c|}{ Total events: 12 (PP), II (no PP) } \\
\hline \multicolumn{6}{|c|}{ Heterogeneity: not applicable } \\
\hline \multicolumn{6}{|c|}{ Test for overall effect: $Z=0.07(P=0.94)$} \\
\hline Test for subgroup diff & ot applic & & & & \\
\hline
\end{tabular}

\section{Analysis I.16. Comparison I Parental presence versus no parental presence, Outcome 16 parental}

satisfaction.

Review: Non-pharmacological interventions for assisting the induction of anaesthesia in children

Comparison: I Parental presence versus no parental presence

Outcome: 16 parental satisfaction

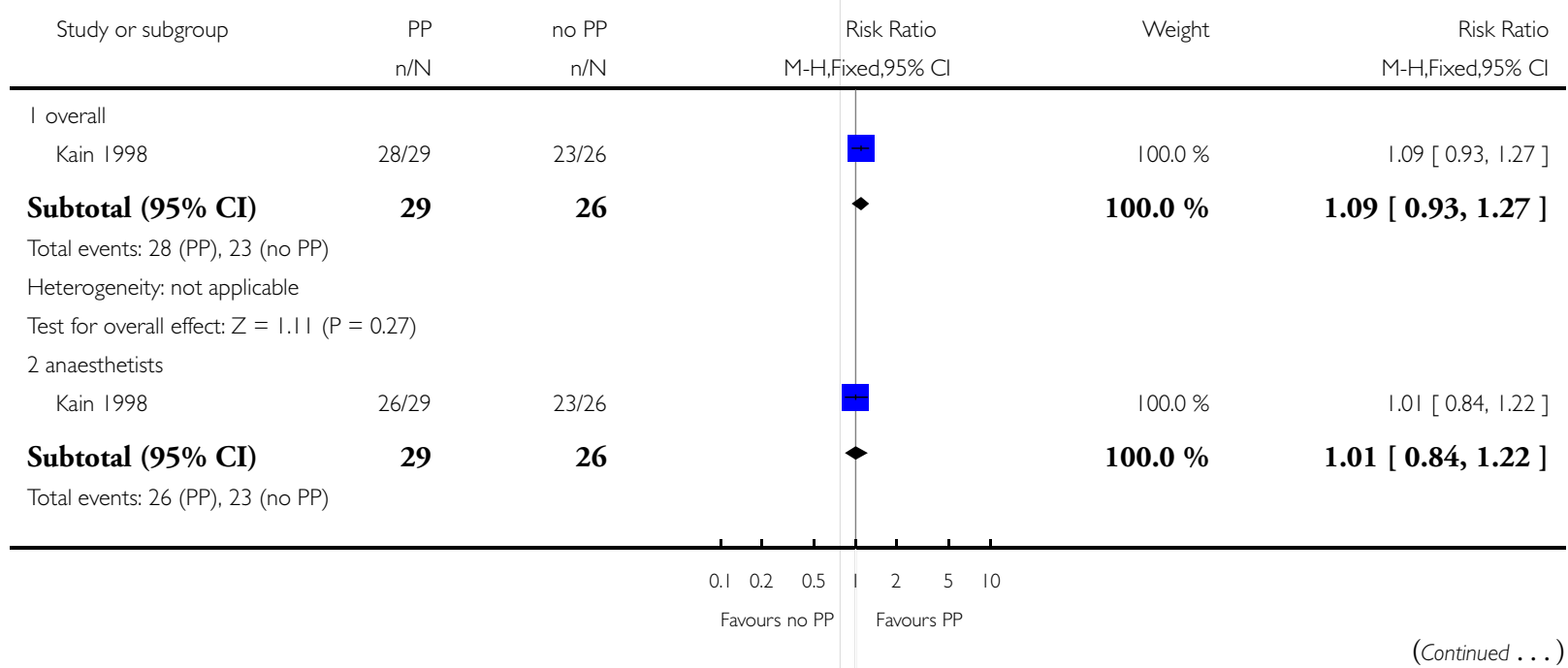

Non-pharmacological interventions for assisting the induction of anaesthesia in children (Review)

Copyright $\Subset 2015$ The Cochrane Collaboration. Published by John Wiley \& Sons, Ltd. 


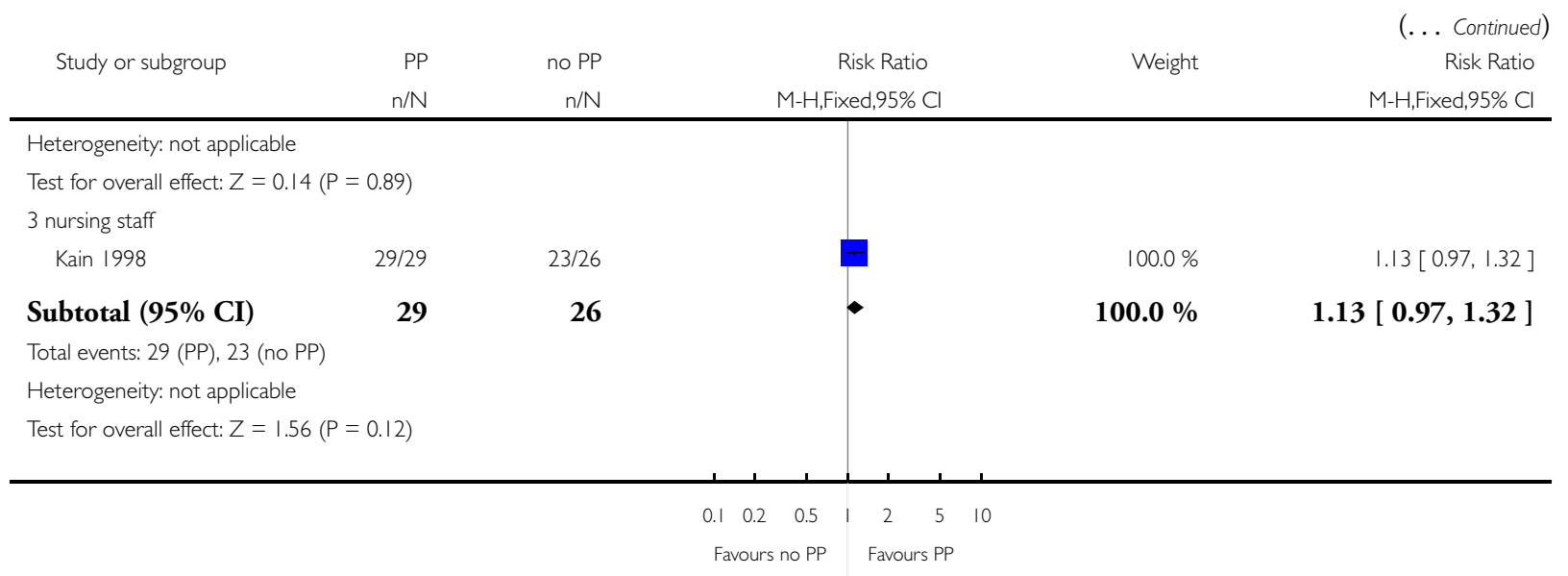

\section{Analysis I.I7. Comparison I Parental presence versus no parental presence, Outcome 17 parental} satisfaction.

Review: Non-pharmacological interventions for assisting the induction of anaesthesia in children

Comparison: I Parental presence versus no parental presence

Outcome: 17 parental satisfaction

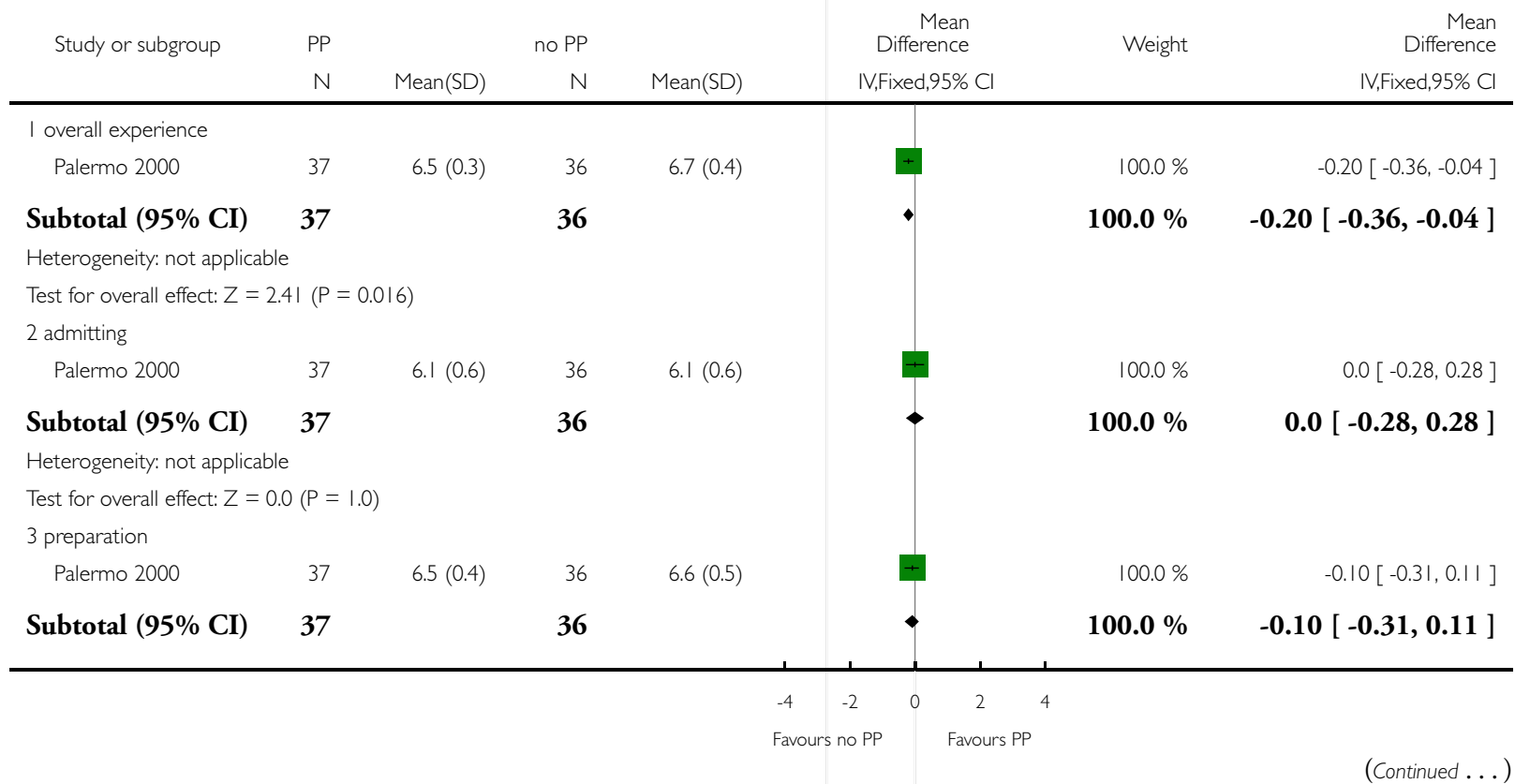

Non-pharmacological interventions for assisting the induction of anaesthesia in children (Review)

Copyright $\odot 2015$ The Cochrane Collaboration. Published by John Wiley \& Sons, Ltd. 


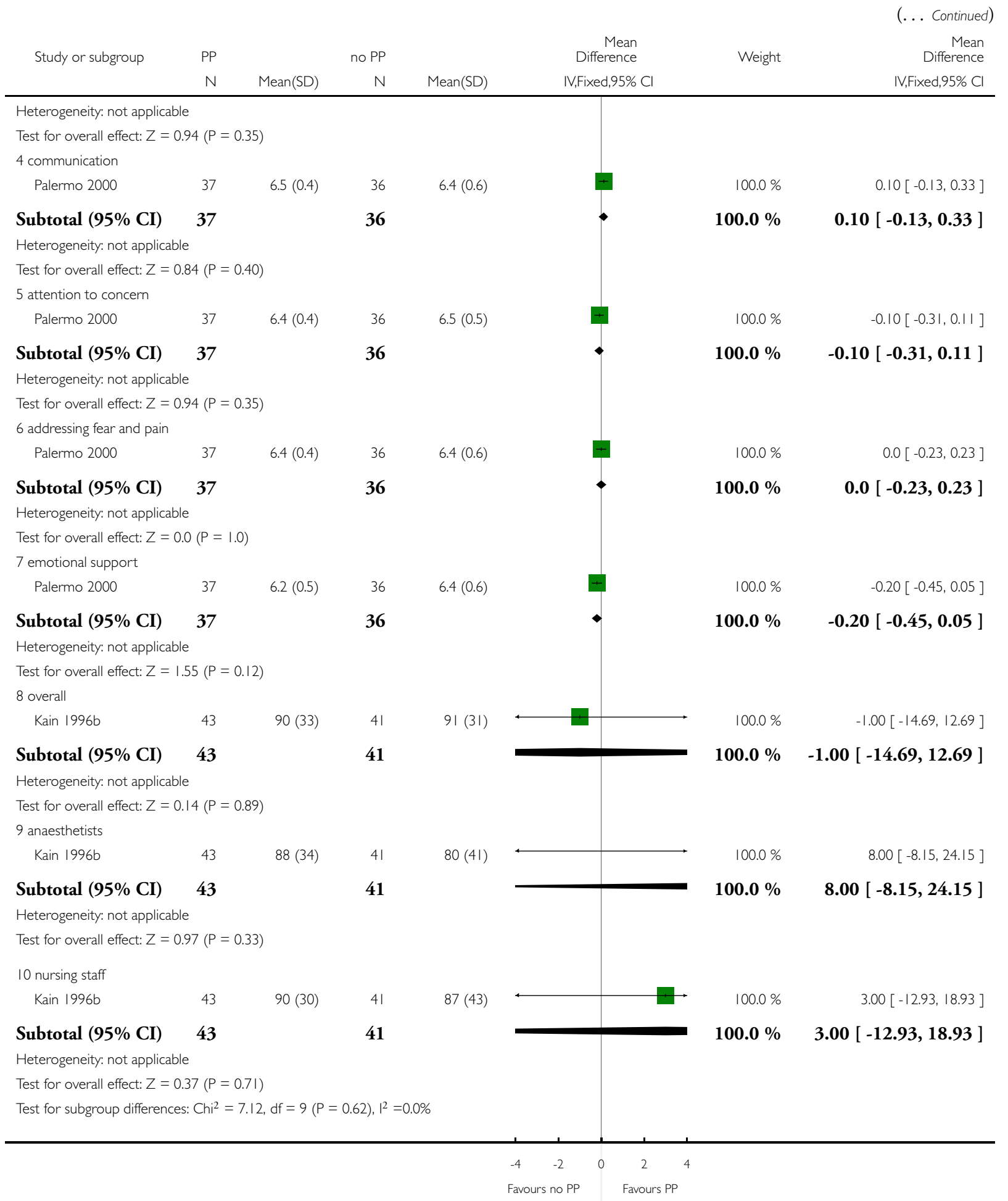

Non-pharmacological interventions for assisting the induction of anaesthesia in children (Review)

Copyright $\odot 2015$ The Cochrane Collaboration. Published by John Wiley \& Sons, Ltd. 


\section{Analysis I.I8. Comparison I Parental presence versus no parental presence, Outcome I8 parental satisfaction.}

parental satisfaction

\begin{tabular}{|c|c|c|}
\hline Study & satisfaction with overall care & satisfaction with separation process \\
\hline Kain 2000 & $\mathrm{P}=0.046$ in favour of parental presence + midazolam & $\mathrm{P}=0.03$ in favour of parental presence + midazolam \\
\hline
\end{tabular}

\section{Analysis 2.I. Comparison 2 Two parents versus one parent, Outcome I anxiety at induction.}

anxiety at induction

\begin{tabular}{l|lll}
\hline Study & two parents $(\mathbf{n}=\mathbf{2 8})$ & one parent $(\mathbf{n}=\mathbf{3 0})$ & P-value \\
\hline mYPAS & & & \\
\hline Kain 2009 & median, IQR & median, IQR \\
& $79.2(37.5,100)$ & $41.7(29.2,90.1)$ & ns \\
\hline
\end{tabular}

Analysis 2.2. Comparison 2 Two parents versus one parent, Outcome 2 co-operation during induction.

Review: Non-pharmacological interventions for assisting the induction of anaesthesia in children

Comparison: 2 Two parents versus one parent

Outcome: 2 co-operation during induction

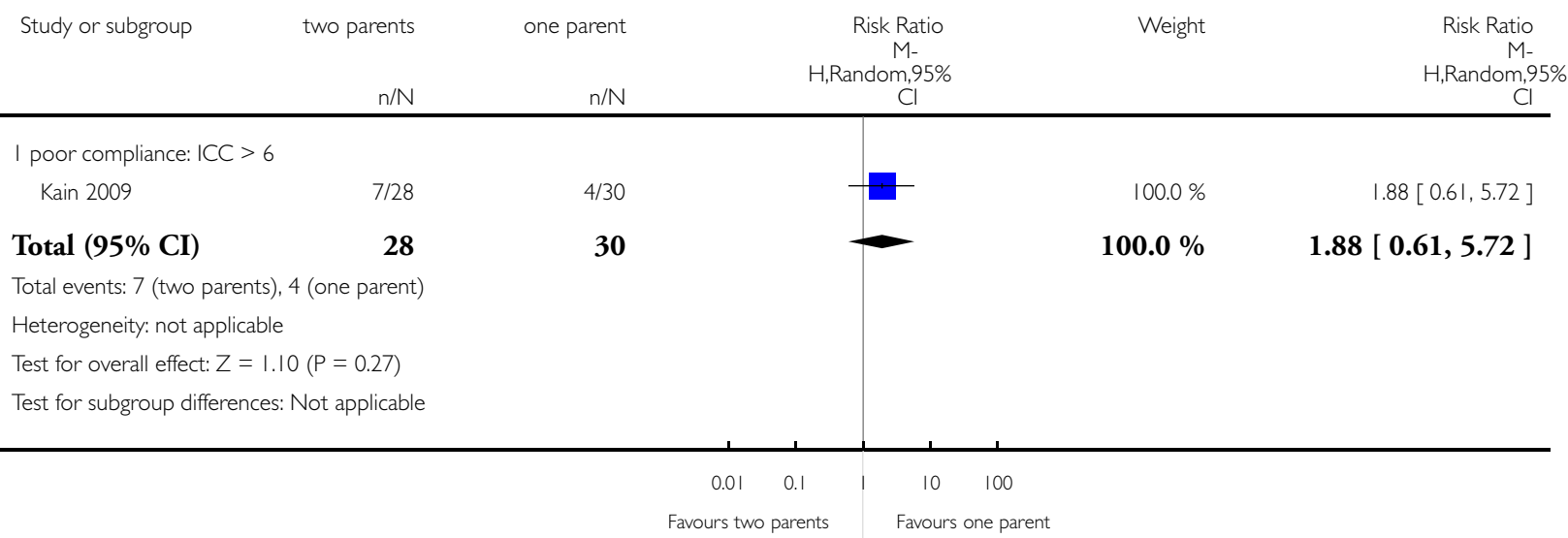


Analysis 2.3. Comparison 2 Two parents versus one parent, Outcome 3 parental anxiety after leaving OR.

Review: Non-pharmacological interventions for assisting the induction of anaesthesia in children

Comparison: 2 Two parents versus one parent

Outcome: 3 parental anxiety after leaving OR

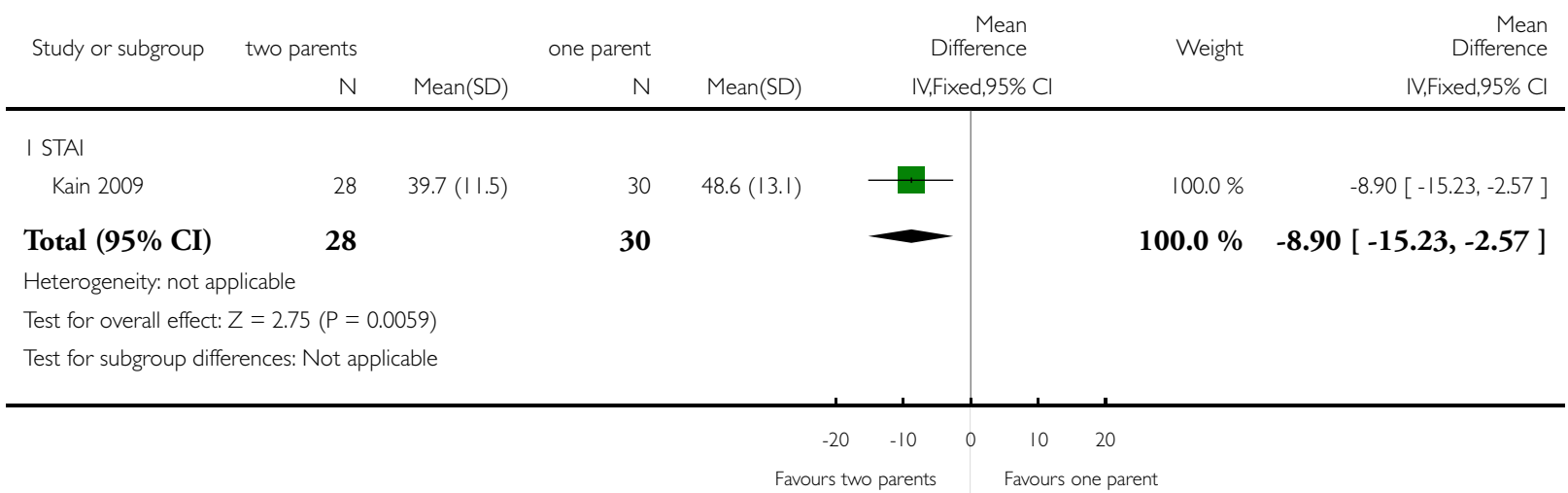

\section{Analysis 3.I. Comparison 3 Parental presence versus midazolam, Outcome I anxiety during induction.}

Review: Non-pharmacological interventions for assisting the induction of anaesthesia in children

Comparison: 3 Parental presence versus midazolam

Outcome: I anxiety during induction

\begin{tabular}{|c|c|c|c|c|c|c|c|c|c|}
\hline \multirow[t]{2}{*}{ Study or subgroup } & \multirow{2}{*}{$\begin{array}{l}\mathrm{PP} \\
\mathrm{N}\end{array}$} & \multirow[b]{2}{*}{ Mean(SD) } & \multirow{2}{*}{$\begin{array}{l}M \\
N\end{array}$} & \multirow{2}{*}{\multicolumn{4}{|c|}{$\begin{array}{c}\text { Mean } \\
\text { Difference } \\
\text { IV,Fixed,95\% Cl }\end{array}$}} & \multirow[t]{2}{*}{ Weight } & \multirow{2}{*}{$\begin{array}{r}\text { Mean } \\
\text { Difference } \\
\text { IV,Fixed,95\% C }\end{array}$} \\
\hline & & & & & & & & & \\
\hline \multicolumn{10}{|l|}{ I mYPAS } \\
\hline Kain 2007 & 94 & $50(26)$ & 98 & $40(24)$ & & & & $100.0 \%$ & $10.00[2.91,17.09]$ \\
\hline Subtotal (95\% CI) & 94 & & 98 & & & & 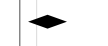 & $100.0 \%$ & $10.00[2.91,17.09]$ \\
\hline \multicolumn{10}{|c|}{ Heterogeneity: not applicable } \\
\hline \multicolumn{10}{|c|}{ Test for overall effect: $Z=2.77(P=0.0057)$} \\
\hline \multicolumn{10}{|c|}{ Test for subgroup differences: Not applicable } \\
\hline & & & & & -50 & -25 & 25 & 50 & \\
\hline \multicolumn{10}{|c|}{ Favours PP $\quad$ Favours $M$} \\
\hline
\end{tabular}


Analysis 3.2. Comparison 3 Parental presence versus midazolam, Outcome 2 anxiety during induction. anxiety during induction

\begin{tabular}{|c|c|c|c|c|}
\hline Study & scale & PP & $\mathbf{M}$ & P value \\
\hline \multicolumn{5}{|c|}{ entrance to $\mathrm{OR}$} \\
\hline Kain 1998 & mYPAS & $\mathrm{n}=29$ & $\mathrm{n}=33$; lower anxiety & 0.0171 \\
\hline \multicolumn{5}{|c|}{ introduction of mask } \\
\hline Kain 1998 & mYPAS & $\mathrm{n}=29$ & $\mathrm{n}=33$; lower anxiety & 0.0176 \\
\hline Kazak 2010 & anxiety scale & $\mathrm{n}=20$ & $\mathrm{n}=20$; lower anxiety & $<0.05$ \\
\hline
\end{tabular}

Analysis 3.3. Comparison 3 Parental presence versus midazolam, Outcome 3 cooperation during induction.

Review: Non-pharmacological interventions for assisting the induction of anaesthesia in children

Comparison: 3 Parental presence versus midazolam

Outcome: 3 cooperation during induction

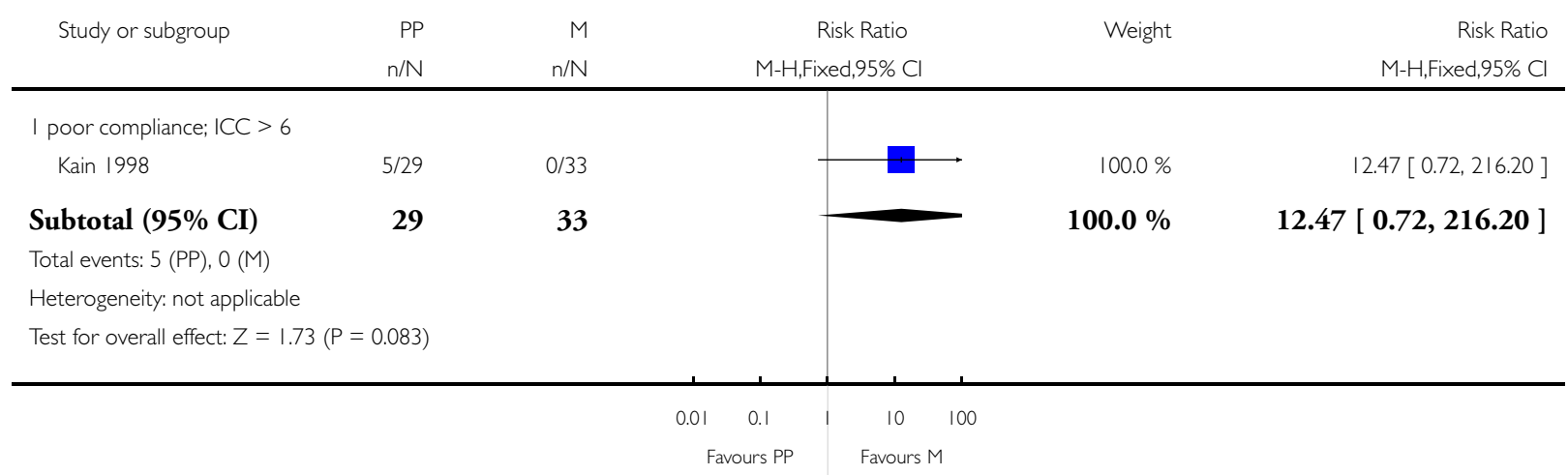

Analysis 3.4. Comparison 3 Parental presence versus midazolam, Outcome 4 cooperation during induction. cooperation during induction

$\begin{array}{ll}\text { Study } & \text { parental presence (median, range): } \mathbf{n} \text { midazolam (median, range): } \mathbf{n}=19 \quad \mathbf{p} \text { value } \\ & =20\end{array}$ quality of mask induction (out of $3 ; 3$ worst)

Non-pharmacological interventions for assisting the induction of anaesthesia in children (Review) 


$\begin{array}{llll}\text { Arai } 2007 & 3(2-3) & 2(1-3) & 0.05\end{array}$

\section{Analysis 3.5. Comparison 3 Parental presence versus midazolam, Outcome 5 parental anxiety.}

Review: Non-pharmacological interventions for assisting the induction of anaesthesia in children

Comparison: 3 Parental presence versus midazolam

Outcome: 5 parental anxiety

\begin{tabular}{|c|c|c|c|c|c|c|c|}
\hline \multirow[t]{2}{*}{ Study or subgroup } & \multirow{2}{*}{$\begin{array}{l}\mathrm{PP} \\
\mathrm{N}\end{array}$} & \multicolumn{2}{|r|}{ M } & \multicolumn{2}{|r|}{$\begin{array}{r}\text { Mean } \\
\text { Difference }\end{array}$} & \multirow[t]{2}{*}{ Weight } & \multirow{2}{*}{$\begin{array}{r}\text { Mean } \\
\text { Difference } \\
\text { IV,Fixed,95\% CI }\end{array}$} \\
\hline & & Mean(SD) & $\mathrm{N}$ & Mean(SD) & IV,Fixed,95\% Cl & & \\
\hline \multicolumn{8}{|l|}{ I STAl } \\
\hline Kain 1998 & 29 & $47(10)$ & 33 & $43(12)$ & 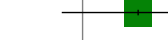 & $100.0 \%$ & $4.00[-1.48,9.48]$ \\
\hline Subtotal $(95 \% \mathrm{CI})$ & 29 & & 33 & & & $100.0 \%$ & $4.00[-1.48,9.48]$ \\
\hline \multicolumn{8}{|c|}{ Heterogeneity: not applicable } \\
\hline \multicolumn{8}{|c|}{ Test for overall effect: $Z=1.43(P=0.15)$} \\
\hline \multicolumn{8}{|c|}{ Test for subgroup differences: Not applicable } \\
\hline
\end{tabular}


Analysis 3.6. Comparison 3 Parental presence versus midazolam, Outcome 6 time taken for induction (minutes).

Review: Non-pharmacological interventions for assisting the induction of anaesthesia in children

Comparison: 3 Parental presence versus midazolam

Outcome: 6 time taken for induction (minutes)

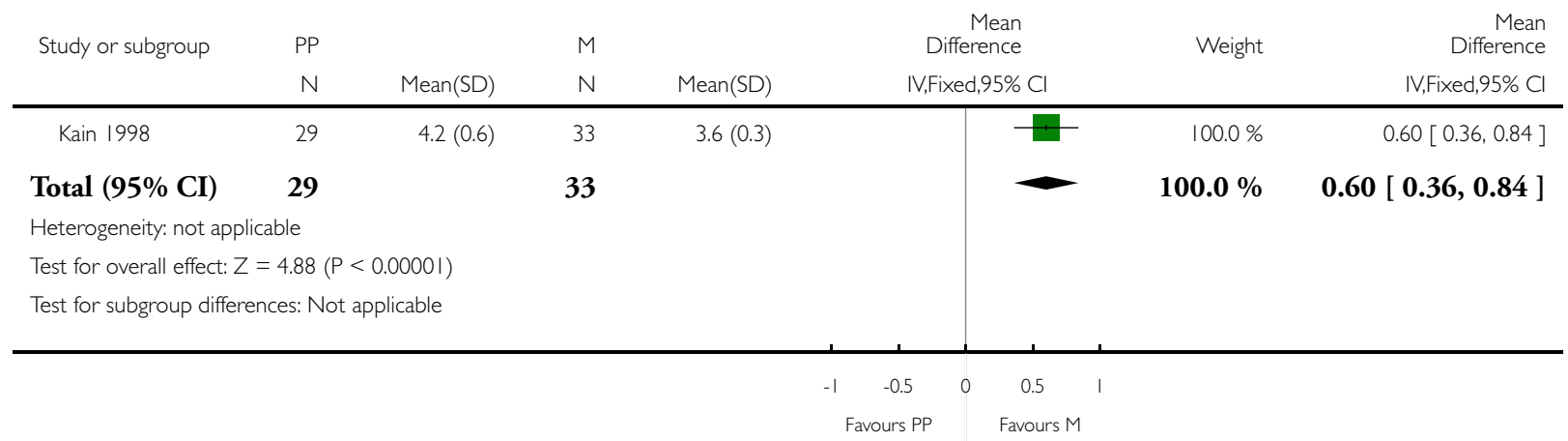

Analysis 3.7. Comparison 3 Parental presence versus midazolam, Outcome 7 emergence delirium.

Review: Non-pharmacological interventions for assisting the induction of anaesthesia in children

Comparison: 3 Parental presence versus midazolam

Outcome: 7 emergence delirium

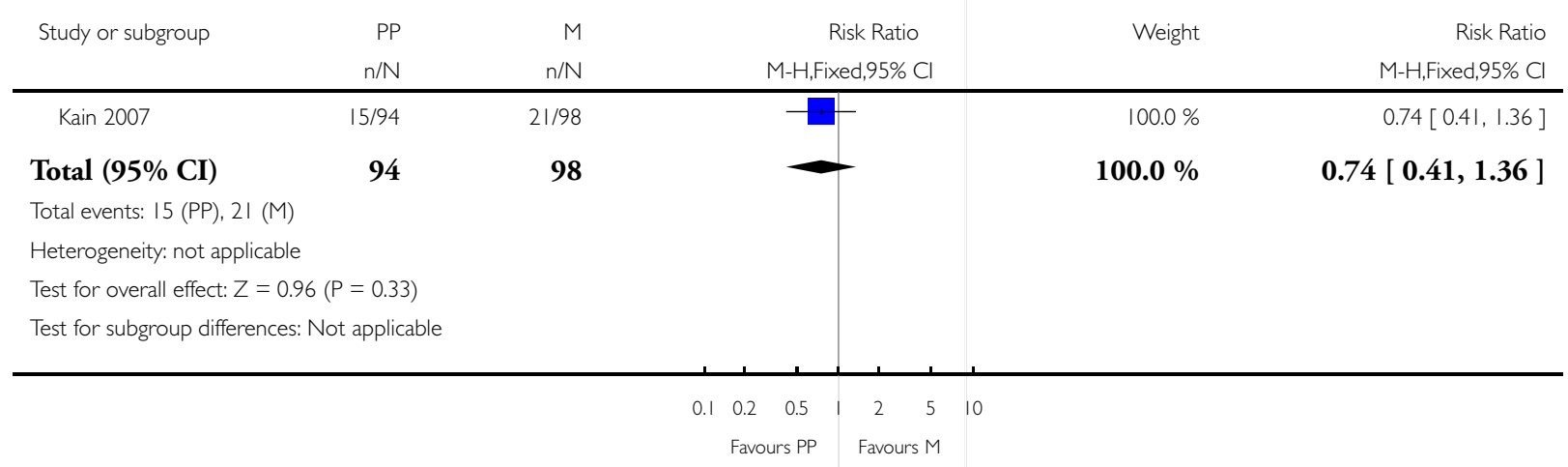


Analysis 3.8. Comparison 3 Parental presence versus midazolam, Outcome 8 emergence delirium. emergence delirium

\begin{tabular}{l|lll}
\hline Study & $\mathbf{P P}($ mean, range) $\mathbf{n}=\mathbf{2 0}$ & $\mathbf{M}($ mean, range) $\mathbf{n}=\mathbf{1 9}$ & $\mathbf{P}$ \\
\hline postoperative excitement score & & $\mathrm{ns}$ \\
\hline Kain $1998 \quad 1(1-1.5)$ & $1(1-2)$ & \\
\hline emergence behaviour (out of $\mathbf{5} ; \mathbf{5}$ worst) & $\mathrm{ns}$ \\
\hline Arai $2007 \quad 4(2-5)$ & $4(2-5)$ & \\
\hline
\end{tabular}

Analysis 3.9. Comparison 3 Parental presence versus midazolam, Outcome 9 negative behaviour postop.

Review: Non-pharmacological interventions for assisting the induction of anaesthesia in children

Comparison: 3 Parental presence versus midazolam

Outcome: 9 negative behaviour postop

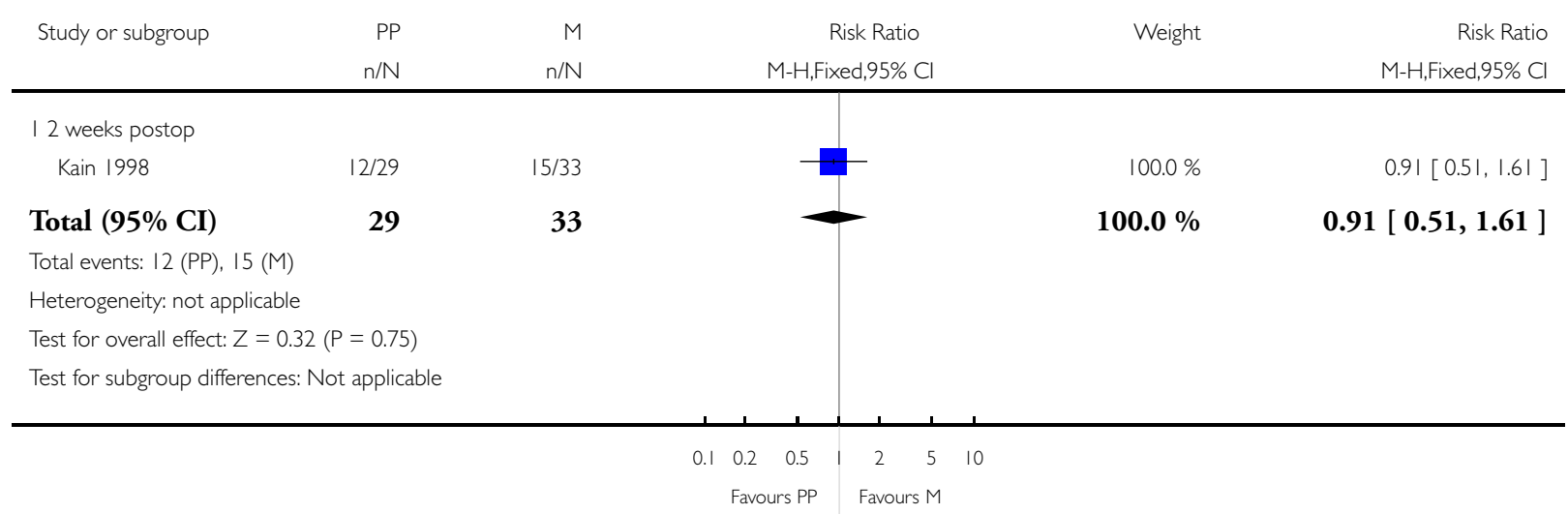


Analysis 3.10. Comparison 3 Parental presence versus midazolam, Outcome 10 parental satisfaction.

Review: Non-pharmacological interventions for assisting the induction of anaesthesia in children

Comparison: 3 Parental presence versus midazolam

Outcome: 10 parental satisfaction

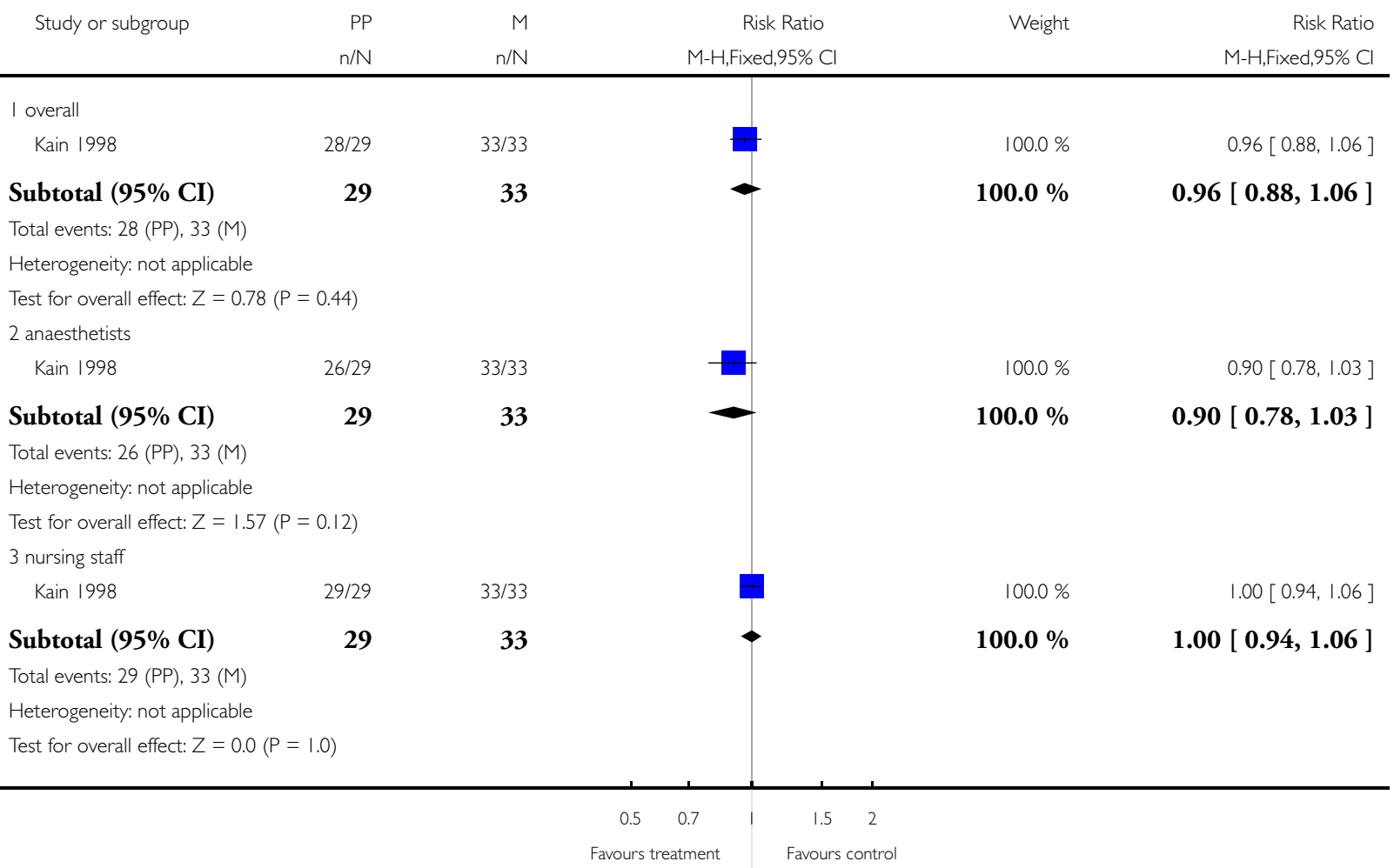


Analysis 4.I. Comparison 4 Parental presence + midazolam versus no parental presence, Outcome I parental anxiety.

Review: Non-pharmacological interventions for assisting the induction of anaesthesia in children

Comparison: 4 Parental presence + midazolam versus no parental presence

Outcome: I parental anxiety

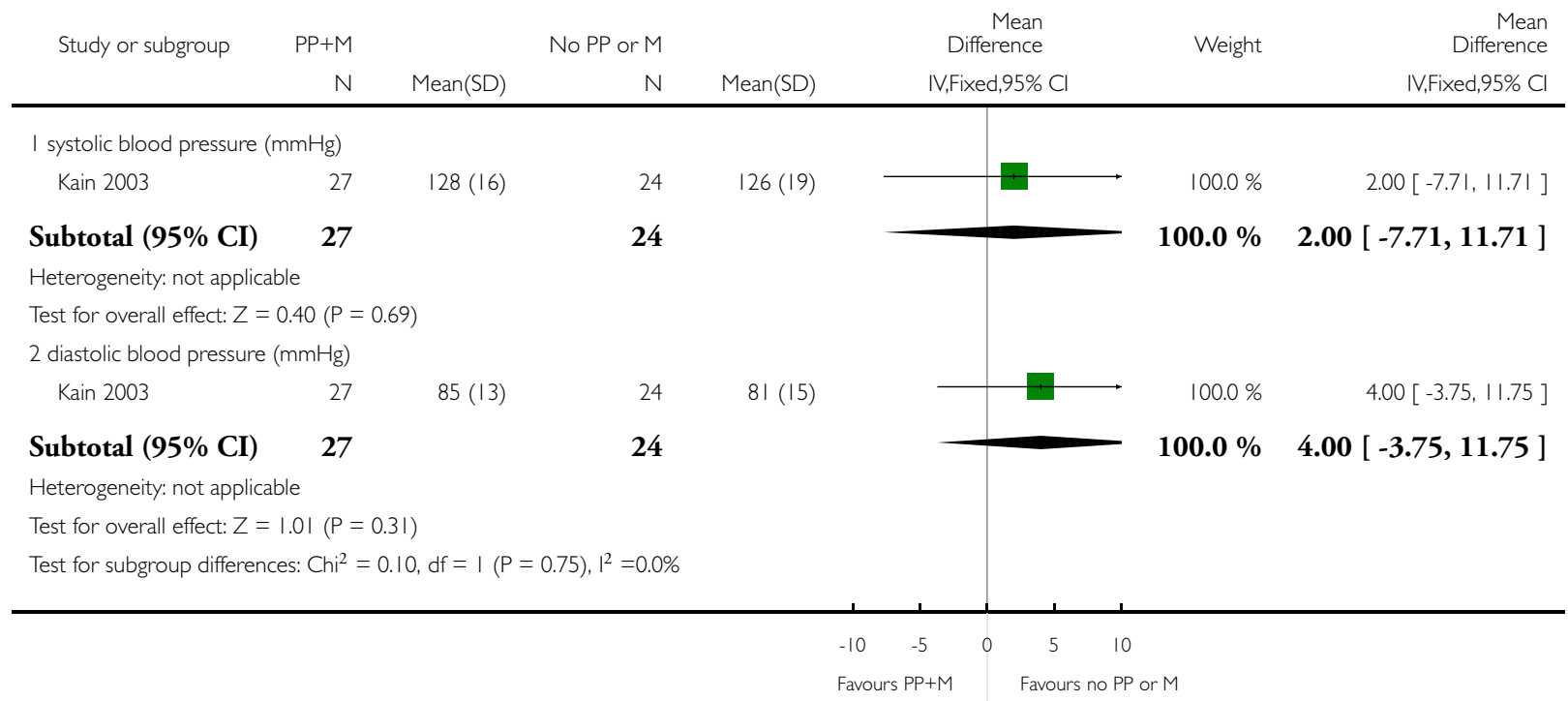


Analysis 4.2. Comparison 4 Parental presence + midazolam versus no parental presence, Outcome 2 parental anxiety.

Review: Non-pharmacological interventions for assisting the induction of anaesthesia in children

Comparison: 4 Parental presence + midazolam versus no parental presence

Outcome: 2 parental anxiety

\begin{tabular}{|c|c|c|c|c|c|}
\hline \multirow[t]{2}{*}{ Study or subgroup } & \multirow{2}{*}{$\begin{array}{r}\mathrm{PP}+\mathrm{M} \\
\mathrm{n} / \mathrm{N}\end{array}$} & \multirow{2}{*}{$\begin{array}{r}\text { no PP or } M \\
n / N\end{array}$} & Risk Ratio & \multirow[t]{2}{*}{ Weight } & \multirow{2}{*}{$\begin{array}{r}\text { Risk Ratio } \\
\text { M-H,Fixed,95\% Cl }\end{array}$} \\
\hline & & & M-H,Fixed,95\% C & & \\
\hline \multicolumn{6}{|c|}{ I isolated ventricular ectopy } \\
\hline Kain 2003 & $3 / 27$ & $3 / 24$ & & $100.0 \%$ & $0.89[0.20,4.00]$ \\
\hline Subtotal $(95 \% \mathrm{CI})$ & 27 & 24 & & $100.0 \%$ & $0.89[0.20,4.00]$ \\
\hline \multicolumn{6}{|c|}{ Total events: 3 (PP+M), 3 (no PP or M) } \\
\hline \multicolumn{6}{|c|}{ Heterogeneity: not applicable } \\
\hline \multicolumn{6}{|c|}{ Test for overall effect: $Z=0.15(P=0.88)$} \\
\hline \multicolumn{6}{|c|}{2 single premature atrial contractions } \\
\hline Kain 2003 & $2 / 27$ & $3 / 24$ & & $100.0 \%$ & $0.59[0.11,3.25]$ \\
\hline Subtotal (95\% CI) & 27 & 24 & & $100.0 \%$ & $0.59[0.11,3.25]$ \\
\hline \multicolumn{6}{|c|}{ Total events: 2 (PP+M), 3 (no PP or M) } \\
\hline \multicolumn{6}{|c|}{ Heterogeneity: not applicable } \\
\hline \multicolumn{6}{|c|}{ Test for overall effect: $Z=0.60(P=0.55)$} \\
\hline
\end{tabular}

Analysis 5.I. Comparison 5 Video 'fairytale', Outcome I co-operation.

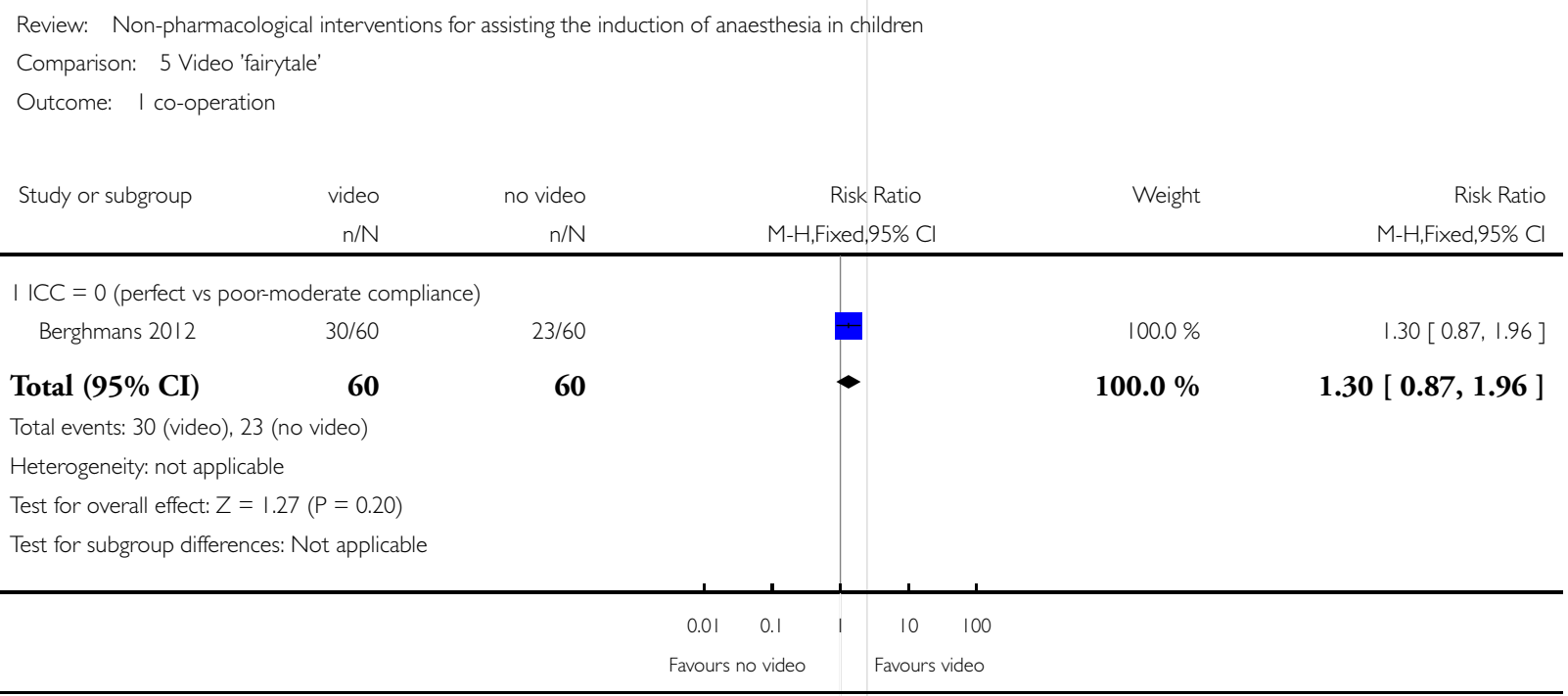




\section{Analysis 5.2. Comparison 5 Video 'fairytale', Outcome 2 parental anxiety (STAI $\geq 46$ ).}

Review: Non-pharmacological interventions for assisting the induction of anaesthesia in children

Comparison: 5 Video 'fairytale'

Outcome: 2 parental anxiety (STAI $\geq 46)$

$\begin{array}{llll}\text { Study or subgroup } & \text { video } & \text { Risk Ratio video } & \text { Wisk Ratio }\end{array}$

$\mathrm{n} / \mathrm{N} \quad \mathrm{n} / \mathrm{N}$

M-H,Fixed,95\% Cl

$\mathrm{M}-\mathrm{H}$, Fixed,95\% Cl

I in holding bay

Berghmans 2012

$12 / 60 \quad 22 / 60$

60

$100.0 \%$

$0.55[0.30,1.00]$

Subtotal (95\% CI)

60

$100.0 \%$

$0.55[0.30,1.00]$

Total events: 12 (video), 22 (no video)

Heterogeneity: not applicable

Test for overall effect: $Z=1.96(P=0.050)$

2 after leaving operating theatre

Berghmans 2012 30/60 30/60

60

60

$100.0 \%$

$1.00[0.70,1.43]$

Subtotal (95\% CI)

$100.0 \%$

$1.00[0.70,1.43]$

Total events: 30 (video), 30 (no video)

Heterogeneity: not applicable

Test for overall effect: $Z=0.0(P=1.0)$

Test for subgroup differences: $\mathrm{Chi}^{2}=2.85, \mathrm{df}=\mathrm{I}(\mathrm{P}=0.09), \mathrm{I}^{2}=65 \%$

$\begin{array}{cccc}0.01 \quad 0.1 & 1 & 10 & 100 \\ \text { Favours video } & & \text { Favours no video }\end{array}$




\section{Analysis 5.3. Comparison 5 Video 'fairytale', Outcome 3 parental anxiety (APAIS $\geq 13$ ).}

Review: Non-pharmacological interventions for assisting the induction of anaesthesia in children

Comparison: 5 Video 'fairytale'

Outcome: 3 parental anxiety (APAIS $\geq 13$ )

video no video

Risk Ratio

Weight

Risk Ratio

$n / N$

$n / \mathrm{N}$

M-H,Fixed,95\% C

M-H,Fixed,95\% Cl

I in holding bay

Berghmans 2012

$11 / 60 \quad 21 / 60$

$00.0 \%$

$0.52[0.28,0.99]$

Subtotal (95\% CI)

60

60

$00.0 \%$

$0.52[0.28,0.99]$

Total events: I I (video), 2 I (no video)

Heterogeneity: not applicable

Test for overall effect: $Z=1.99(P=0.046)$

2 after leaving operating theatre

Berghmans $2012 \quad 12 / 60$

60

$26 / 60$

$00.0 \%$

$0.46[0.26,0.83]$

Subtotal (95\% CI)

60

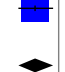

$100.0 \%$

$0.46[0.26,0.83]$

Total events: 12 (video), 26 (no video)

Heterogeneity: not applicable

Test for overall effect: $Z=2.60$ ( $P=0.0093)$

Test for subgroup differences: $\mathrm{Chi}^{2}=0.08, \mathrm{df}=\mathrm{I}(\mathrm{P}=0.77), \mathrm{I}^{2}=0.0 \%$ 


\section{Analysis 5.4. Comparison 5 Video 'fairytale', Outcome 4 parental anxiety (STAI).}

Review: Non-pharmacological interventions for assisting the induction of anaesthesia in children

Comparison: 5 Video 'fairytale'

Outcome: 4 parental anxiety (STAI)

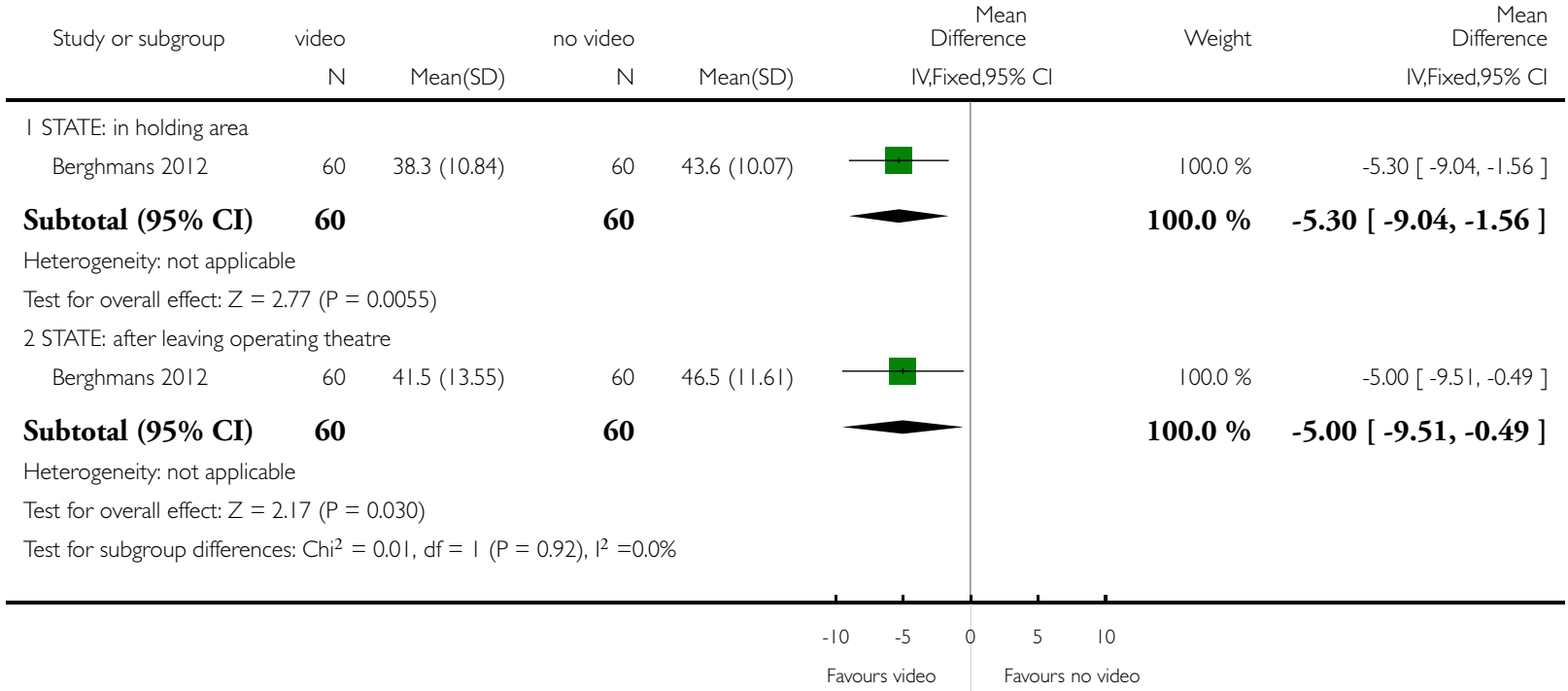




\section{Analysis 5.5. Comparison 5 Video 'fairytale', Outcome 5 parental anxiety (APAIS).}

Review: Non-pharmacological interventions for assisting the induction of anaesthesia in children

Comparison: 5 Video 'fairytale'

Outcome: 5 parental anxiety (APAIS)

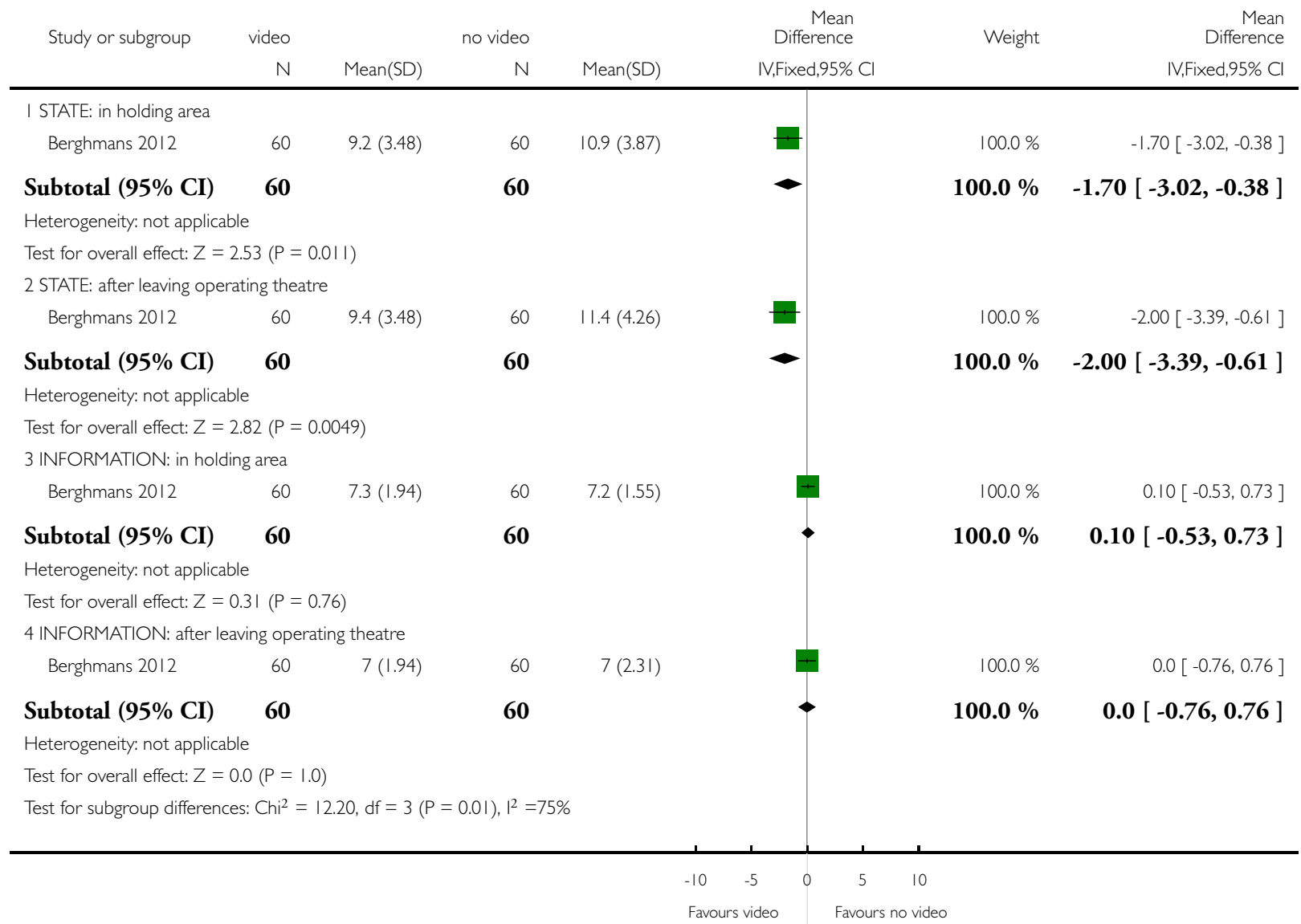




\section{Analysis 6.I. Comparison 6 Low sensory stimulation versus control, Outcome I co-operation at induction.}

Review: Non-pharmacological interventions for assisting the induction of anaesthesia in children

Comparison: 6 Low sensory stimulation versus control

Outcome: I co-operation at induction

\begin{tabular}{|c|c|c|c|c|c|}
\hline \multirow[t]{2}{*}{ Study or subgroup } & LSSG & Control & Risk Ratio & \multirow[t]{2}{*}{ Weight } & Risk Ratio \\
\hline & $\mathrm{n} / \mathrm{N}$ & $\mathrm{n} / \mathrm{N}$ & M-H,Fixed,95\% Cl & & M-H,Fixed,95\% Cl \\
\hline \multicolumn{6}{|l|}{$I I C C=0$} \\
\hline Kain 200I & $17 / 33$ & $29 / 37$ & & $100.0 \%$ & $0.66[0.45,0.95]$ \\
\hline Subtotal (95\% CI) & 33 & 37 & & $100.0 \%$ & $0.66[0.45,0.95]$ \\
\hline \multicolumn{6}{|c|}{ Total events: 17 (LSSG), 29 (Control) } \\
\hline \multicolumn{6}{|c|}{ Heterogeneity: not applicable } \\
\hline \multicolumn{6}{|c|}{ Test for overall effect: $Z=2.21(P=0.027)$} \\
\hline
\end{tabular}

\section{$\begin{array}{lllllll}0.1 & 0.2 & 0.5 & 1 & 2 & 5 & 10\end{array}$}

Favours LSSG Favours control

Analysis 6.2. Comparison 6 Low sensory stimulation versus control, Outcome 2 parental anxiety.

Review: Non-pharmacological interventions for assisting the induction of anaesthesia in children

Comparison: 6 Low sensory stimulation versus control

Outcome: 2 parental anxiety

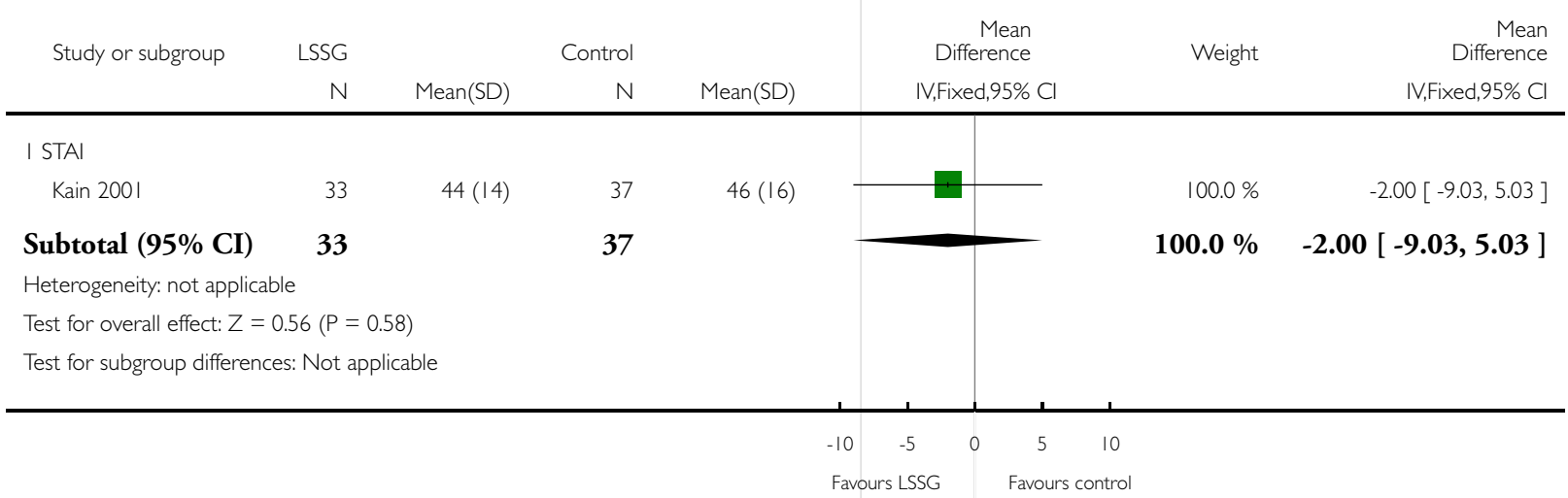




\section{Analysis 7.I. Comparison 7 Mask introduction/exposure, Outcome I anxiety.}

Review: Non-pharmacological interventions for assisting the induction of anaesthesia in children

Comparison: 7 Mask introduction/exposure

Outcome: I anxiety

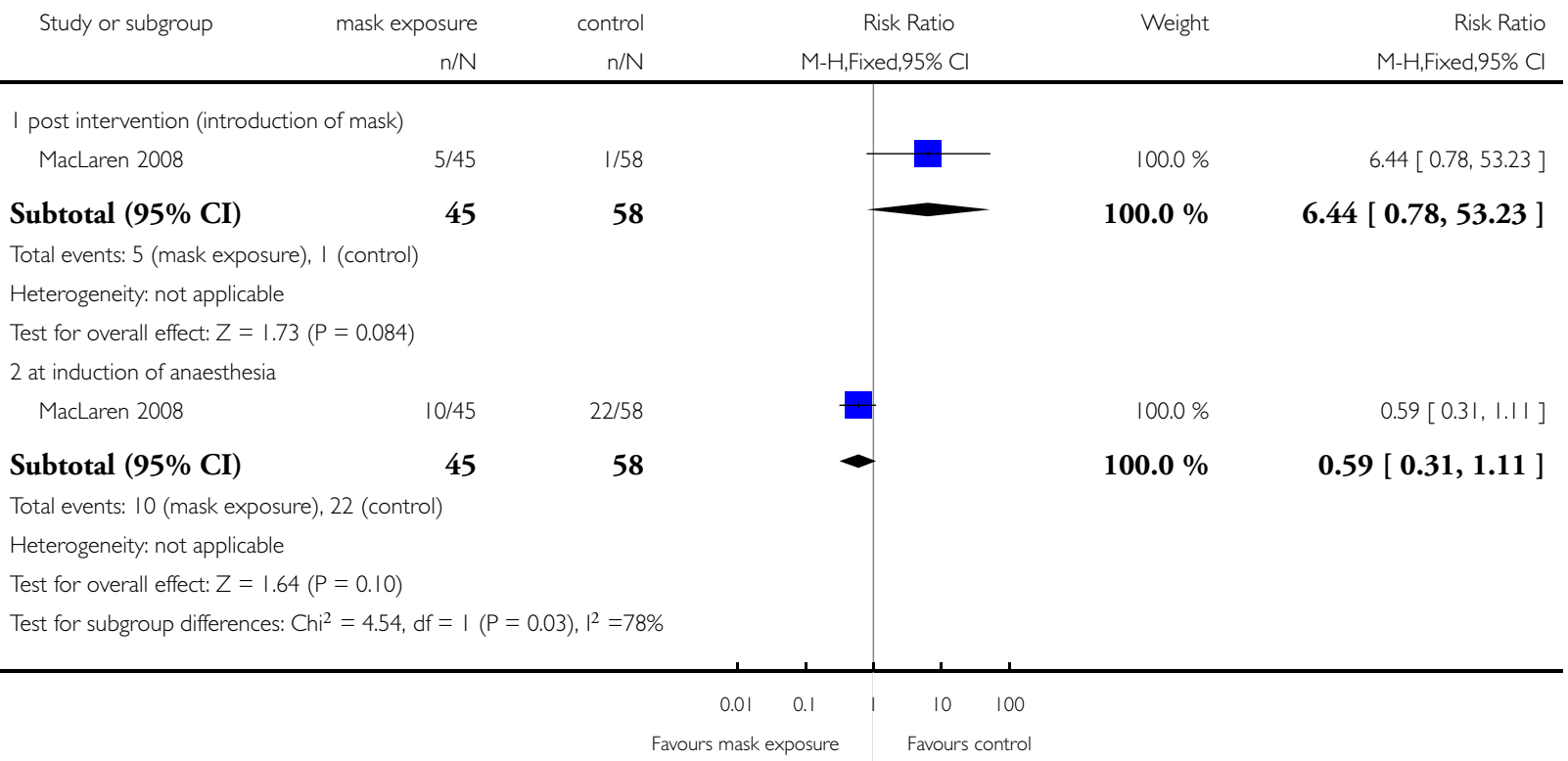




\section{Analysis 7.2. Comparison 7 Mask introduction/exposure, Outcome 2 co-operation (ICC): number of children compliant.}

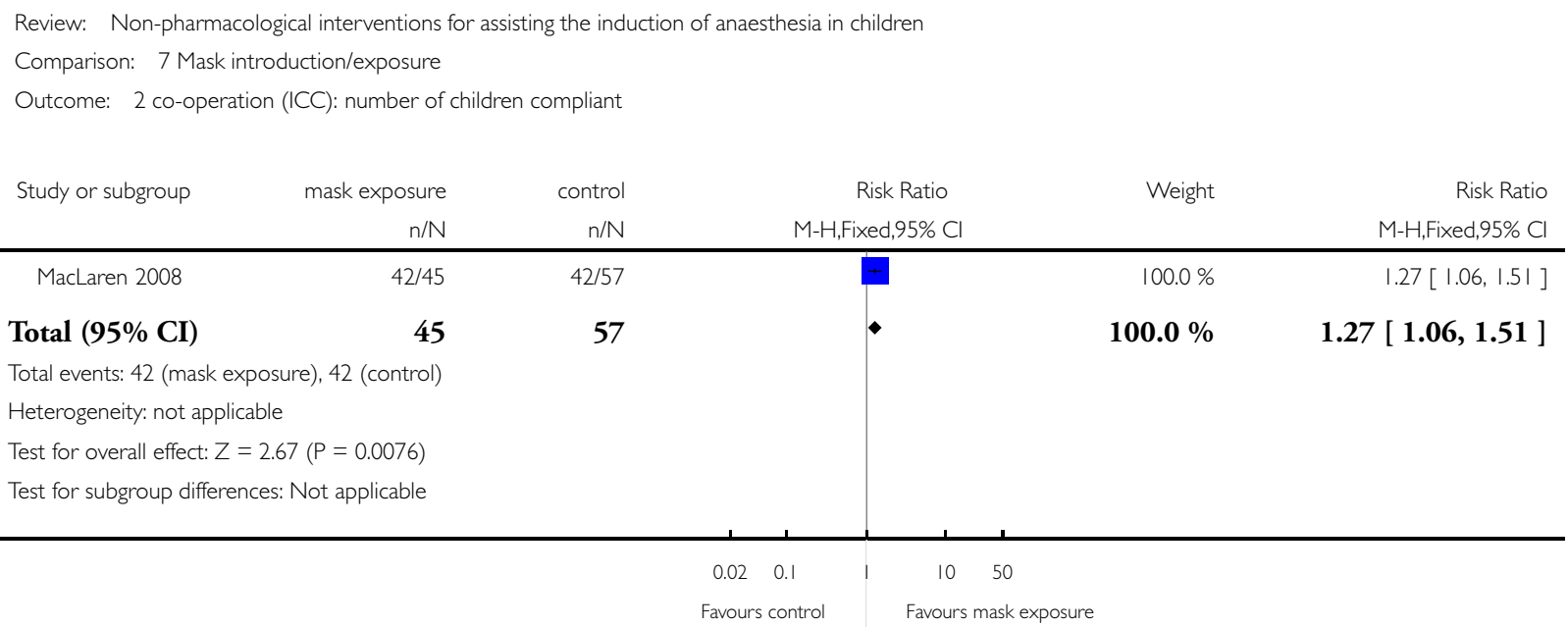

Analysis 7.3. Comparison 7 Mask introduction/exposure, Outcome 3 parental anxiety (STAl: trait).

Review: Non-pharmacological interventions for assisting the induction of anaesthesia in children

Comparison: 7 Mask introduction/exposure

Outcome: 3 parental anxiety (STAl: trait)

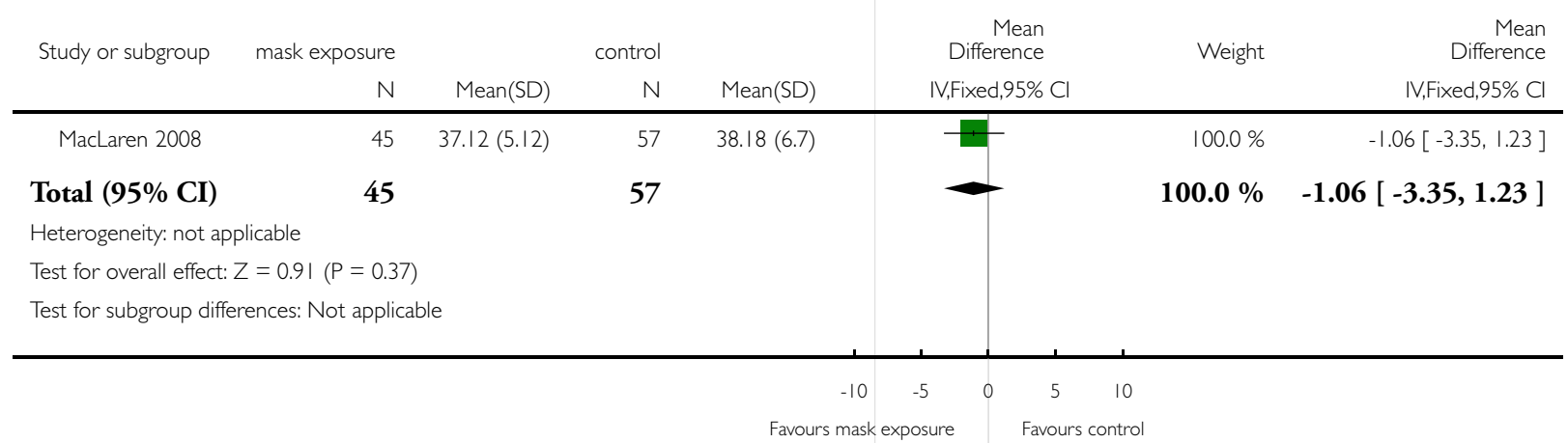


Analysis 8.1. Comparison 8 Computer preparation versus control, Outcome I co-operation during induction.

co-operation during induction

\begin{tabular}{|c|c|c|c|c|c|}
\hline Study & $\begin{array}{l}\text { PP (VAS - median, } \\
\text { range) }\end{array}$ & PP (n) & $\begin{array}{l}\text { PP+computer (VAS - } \\
\text { median, range) }\end{array}$ & PP+computer (n) & p value \\
\hline \multicolumn{6}{|l|}{ coping VAS } \\
\hline Campbell 2005 & $3(0-10)$ & 58 & $1(0-10)$ & 55 & 0.014 \\
\hline
\end{tabular}

Analysis 8.2. Comparison 8 Computer preparation versus control, Outcome 2 negative behavioural changes.

negative behavioural changes

\begin{tabular}{|c|c|c|c|c|c|}
\hline Study & $\begin{array}{l}\text { PP (VAS - median, } \\
\text { range) }\end{array}$ & PP (n) & $\begin{array}{l}\text { PP+computer (VAS - } \\
\text { median, range) }\end{array}$ & PP+computer (n) & p value \\
\hline \multicolumn{6}{|l|}{ coping VAS } \\
\hline Campbell 2005 & $2.5(0-10)$ & 56 & $0(0-10)$ & 55 & 0.121 \\
\hline
\end{tabular}

Analysis 9.1. Comparison 9 Cartoon preparation versus control, Outcome I co-operation during induction. co-operation during induction

\begin{tabular}{|c|c|c|c|c|c|}
\hline Study & $\begin{array}{l}\text { PP (VAS - median, } \\
\text { range) }\end{array}$ & $\mathbf{P P}(\mathbf{n})$ & $\begin{array}{l}\text { PP+cartoon (VAS - me- } \\
\text { dian, range) }\end{array}$ & PP+cartoon (n) & p value \\
\hline \multicolumn{6}{|l|}{ coping VAS } \\
\hline Campbell 2005 & $3(0-10)$ & 58 & $1(0-10)$ & 55 & 0.076 \\
\hline
\end{tabular}

Analysis 9.2. Comparison 9 Cartoon preparation versus control, Outcome 2 negative behavioural changes. negative behavioural changes

\begin{tabular}{|c|c|c|c|c|c|}
\hline Study & $\begin{array}{l}\text { PP (VAS - median, } \\
\text { range) }\end{array}$ & PP (n) & $\begin{array}{l}\text { PP+cartoon (VAS - me- } \\
\text { dian, range) }\end{array}$ & PP+cartoon (n) & $p$ value \\
\hline \multicolumn{6}{|l|}{ coping VAS } \\
\hline Campbell 2005 & $2.5(0-10)$ & 56 & $4(0-10)$ & 55 & 0.36 \\
\hline
\end{tabular}


Analysis 10.I. Comparison I0 Computer versus cartoon preparation, Outcome I co-operation during induction.

co-operation during induction

\begin{tabular}{|c|c|c|c|c|c|}
\hline Study & $\begin{array}{l}\text { PP+computer (VAS } \\
\text { - median, range) }\end{array}$ & PP+computer (n) & $\begin{array}{l}\text { PP+cartoon (VAS - } \\
\text { median, range) }\end{array}$ & PP+cartoon (n) & p value \\
\hline \multicolumn{6}{|c|}{ coping VAS (0-10) } \\
\hline Campbell 2005 & $1(0-10)$ & 55 & $1(0-10)$ & 55 & 0.798 \\
\hline
\end{tabular}

Analysis 10.2. Comparison 10 Computer versus cartoon preparation, Outcome 2 negative behavioural change.

negative behavioural change

\begin{tabular}{|c|c|c|c|c|c|}
\hline Study & $\begin{array}{l}\text { PP+computer (VAS } \\
\text { - median, range) }\end{array}$ & PP+computer (n) & $\begin{array}{l}\text { PP+cartoon (VAS - } \\
\text { median, range) }\end{array}$ & PP+cartoon (n) & p value \\
\hline \multicolumn{6}{|c|}{ coping VAS $(0-10)$} \\
\hline Campbell 2005 & $0(0-10)$ & 55 & $4(0-10)$ & 55 & 0.016 \\
\hline
\end{tabular}

\section{Analysis I I.I. Comparison I I Video game versus control, Outcome I anxiety during induction.}

Review: Non-pharmacological interventions for assisting the induction of anaesthesia in children

Comparison: I I Video game versus control

Outcome: I anxiety during induction

\begin{tabular}{|c|c|c|c|c|c|c|c|c|c|}
\hline \multirow[t]{2}{*}{ Study or subgroup } & Video game & \multicolumn{3}{|c|}{ Control } & \multicolumn{3}{|c|}{$\begin{array}{r}\text { Mean } \\
\text { Difference }\end{array}$} & \multirow[t]{2}{*}{ Weight } & \multirow{2}{*}{$\begin{array}{r}\text { Mean } \\
\text { Difference } \\
\text { IV,Fixed,95\% Cl }\end{array}$} \\
\hline & $\mathrm{N}$ & Mean(SD) & $\mathrm{N}$ & Mean(SD) & & & ed,95\% Cl & & \\
\hline \multicolumn{10}{|l|}{ I mYPAS } \\
\hline Patel 2006 & 38 & $41.7(25.27)$ & 36 & $51.5(16.2)$ & & & & $100.0 \%$ & $-9.80[-19.42,-0.18]$ \\
\hline Subtotal (95\% CI) & 38 & & 36 & & & & & $100.0 \%$ & $-9.80[-19.42,-0.18]$ \\
\hline \multicolumn{10}{|c|}{ Heterogeneity: not applicable } \\
\hline \multicolumn{10}{|c|}{ Test for overall effect: $Z=2.00(P=0.046)$} \\
\hline \multicolumn{10}{|c|}{ Test for subgroup differences: Not applicable } \\
\hline & & & & & -20 & -10 & 10 & 20 & \\
\hline
\end{tabular}




\section{Analysis II.2. Comparison I I Video game versus control, Outcome 2 negative behaviour postop.}

Review: Non-pharmacological interventions for assisting the induction of anaesthesia in children

Comparison: II Video game versus control

Outcome: 2 negative behaviour postop

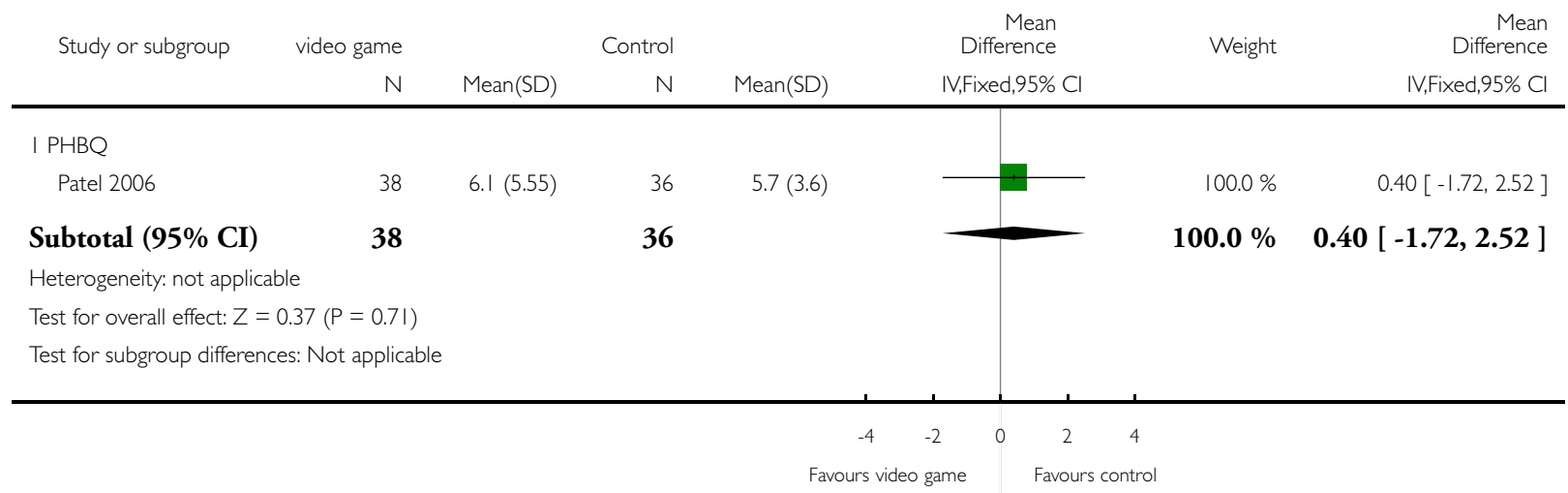

Analysis I2.I. Comparison I2 Video game versus midazolam, Outcome I anxiety during induction.

Review: Non-pharmacological interventions for assisting the induction of anaesthesia in children

Comparison: 12 Video game versus midazolam

Outcome: I anxiety during induction

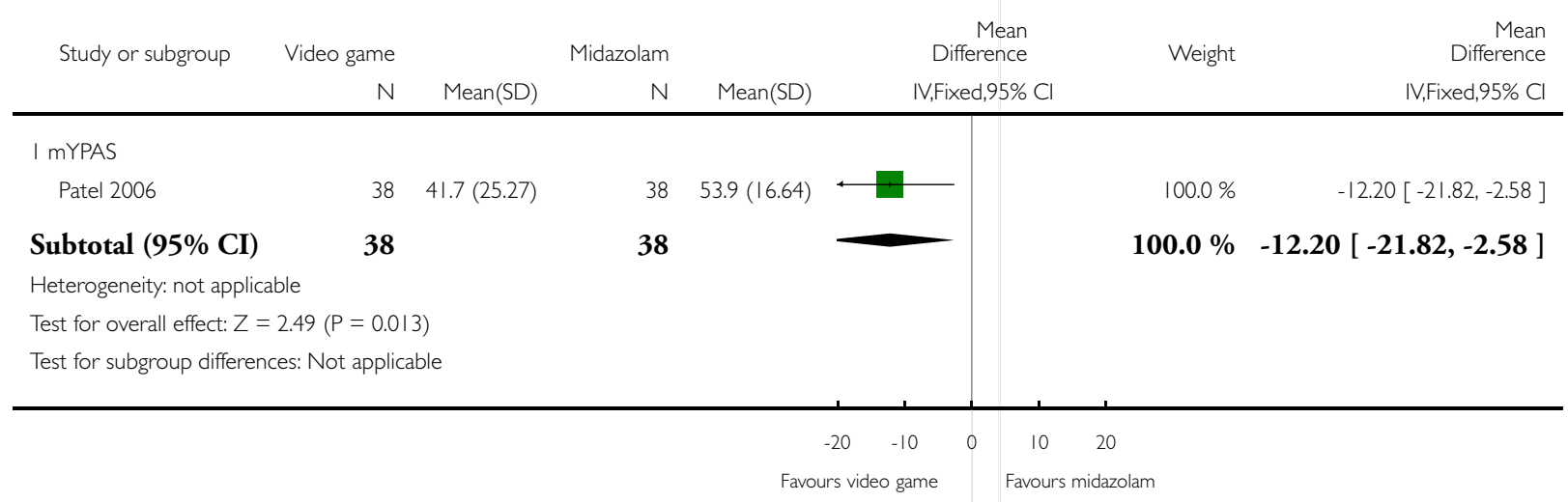


Analysis 12.2. Comparison 12 Video game versus midazolam, Outcome 2 negative behaviour postop.

Review: Non-pharmacological interventions for assisting the induction of anaesthesia in children

Comparison: 12 Video game versus midazolam

Outcome: 2 negative behaviour postop

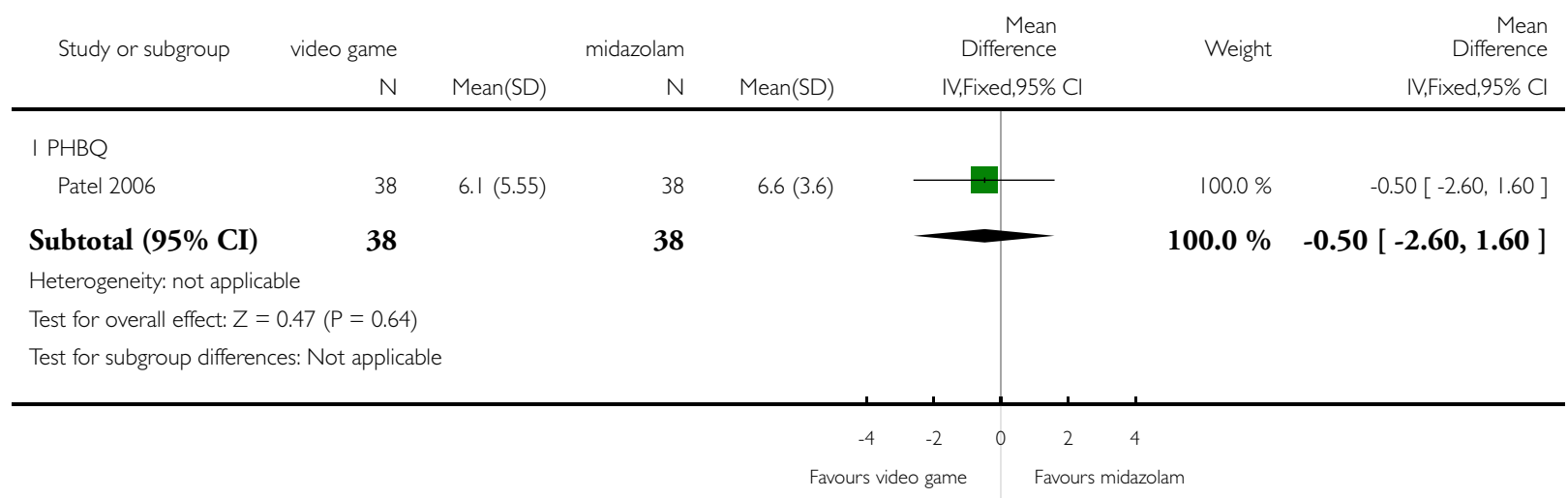

Analysis 13.I. Comparison 13 Clowns/clown doctors versus parental presence, Outcome I anxiety.

Review: Non-pharmacological interventions for assisting the induction of anaesthesia in children

Comparison: 13 Clowns/clown doctors versus parental presence

Outcome: I anxiety

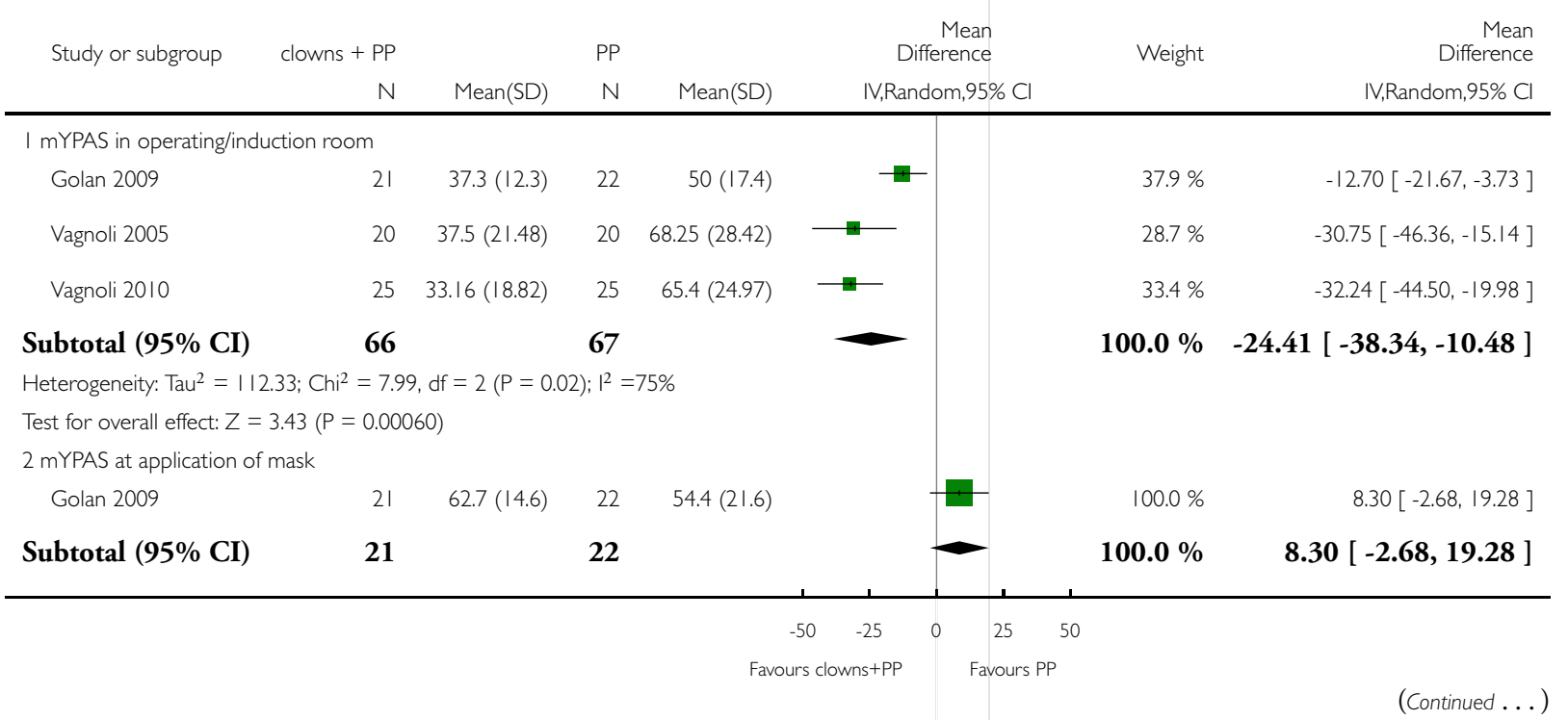

Non-pharmacological interventions for assisting the induction of anaesthesia in children (Review)

Copyright @ 2015 The Cochrane Collaboration. Published by John Wiley \& Sons, Ltd. 


\begin{tabular}{|c|c|c|c|c|c|c|c|}
\hline \multirow[t]{2}{*}{ Study or subgroup } & clowns + PP & & PP & & \multirow{2}{*}{$\begin{array}{c}\text { Mean } \\
\text { Difference } \\
\text { IV,Random,95\% Cl }\end{array}$} & \multirow[t]{2}{*}{ Weight } & \multirow{2}{*}{$\begin{array}{r}\text { (... Continued) } \\
\text { Mean } \\
\text { Difference } \\
\text { IV,Random,95\% Cl }\end{array}$} \\
\hline & $\mathrm{N}$ & Mean(SD) & $\mathrm{N}$ & Mean(SD) & & & \\
\hline \multicolumn{8}{|c|}{ Heterogeneity: not applicable } \\
\hline \multicolumn{8}{|c|}{ Test for overall effect: $Z=1.48(P=0.14)$} \\
\hline \multicolumn{8}{|l|}{3 CSWQ - hospitalisation } \\
\hline Fernandes 2010 & 35 & $0.85(0.45)$ & 35 & $1.95(0.67)$ & & $100.0 \%$ & $-1.10[-1.37,-0.83]$ \\
\hline Subtotal $(95 \% \mathrm{CI})$ & 35 & & 35 & & & $100.0 \%$ & $-1.10[-1.37,-0.83]$ \\
\hline \multicolumn{8}{|l|}{ Heterogeneity: not applicable } \\
\hline \multicolumn{8}{|c|}{ Test for overall effect: $Z=8.06(P<0.0000 \mathrm{I})$} \\
\hline \multicolumn{8}{|c|}{4 CSWQ - medical procedures } \\
\hline Fernandes 2010 & 35 & $0.95(0.73)$ & 35 & $2.2(0.92)$ & & $100.0 \%$ & $-1.25[-1.64,-0.86]$ \\
\hline Subtotal $(95 \% \mathrm{CI})$ & 35 & & 35 & & & $100.0 \%$ & $-1.25[-1.64,-0.86]$ \\
\hline \multicolumn{8}{|c|}{ Heterogeneity: not applicable } \\
\hline \multicolumn{8}{|c|}{ Test for overall effect: $Z=6.30(P<0.0000$ I) } \\
\hline \multicolumn{8}{|c|}{5 CSWQ - illness and consequences } \\
\hline Fernandes 2010 & 35 & $1.04(0.75)$ & 35 & $2.61(0.78)$ & & $100.0 \%$ & $-1.57[-1.93,-1.21]$ \\
\hline Subtotal (95\% CI) & 35 & & 35 & & ' & $100.0 \%$ & $-1.57[-1.93,-1.21]$ \\
\hline \multicolumn{8}{|c|}{ Heterogeneity: not applicable } \\
\hline \multicolumn{8}{|c|}{ Test for overall effect: $Z=8.58(P<0.0000$ I $)$} \\
\hline \multicolumn{8}{|l|}{6 FAS } \\
\hline Meisel 2009 & 28 & $0.38(0.32)$ & 33 & $0.32(0.29)$ & & $100.0 \%$ & $0.06[-0.09,0.21]$ \\
\hline Subtotal $(95 \% \mathrm{CI})$ & 28 & & 33 & & & $100.0 \%$ & $0.06[-0.09,0.21]$ \\
\hline \multicolumn{8}{|c|}{ Heterogeneity: not applicable } \\
\hline \multicolumn{8}{|c|}{ Test for overall effect: $Z=0.76(P=0.45)$} \\
\hline \multicolumn{8}{|c|}{ Test for subgroup differences: Chi $^{2}=131.99, \mathrm{df}=5(P=0.00), 1^{2}=96 \%$} \\
\hline
\end{tabular}




\section{Analysis 13.2. Comparison I 3 Clowns/clown doctors versus parental presence, Outcome 2 co-operation at induction.}

Review: Non-pharmacological interventions for assisting the induction of anaesthesia in children

Comparison: 13 Clowns/clown doctors versus parental presence

Outcome: 2 co-operation at induction

\begin{tabular}{|c|c|c|c|c|c|c|c|}
\hline \multirow[t]{2}{*}{ Study or subgroup } & \multicolumn{2}{|l|}{ clowns $+\mathrm{PP}$} & \multicolumn{2}{|l|}{ PP } & \multirow{2}{*}{$\begin{array}{c}\text { Mean } \\
\text { Difference } \\
\text { IV,Random,95\% Cl }\end{array}$} & \multirow[t]{2}{*}{ Weight } & \multirow{2}{*}{$\begin{array}{r}\text { Mean } \\
\text { Difference } \\
\text { IV,Random,95\% Cl }\end{array}$} \\
\hline & N & Mean(SD) & N & Mean(SD) & & & \\
\hline \multicolumn{8}{|l|}{ I SAM - affective valence } \\
\hline Fernandes 2010 & 35 & $8.14(1.19)$ & 35 & $6.06(1.59)$ & + & $100.0 \%$ & $2.08[1.42,2.74]$ \\
\hline Subtotal (95\% CI) & 35 & & 35 & & $\bullet$ & $100.0 \%$ & $2.08[1.42,2.74]$ \\
\hline \multicolumn{8}{|c|}{ Heterogeneity: not applicable } \\
\hline \multicolumn{8}{|c|}{ Test for overall effect: $Z=6.20(P<0.0000 I)$} \\
\hline \multicolumn{8}{|c|}{2 SAM - arousal } \\
\hline Fernandes 2010 & 35 & $1.66(0.69)$ & 35 & $3.36(1.77)$ & + & $100.0 \%$ & $-1.70[-2.33,-1.07]$ \\
\hline Subtotal (95\% CI) & 35 & & 35 & & $\bullet$ & $100.0 \%$ & $-1.70[-2.33,-1.07]$ \\
\hline \multicolumn{8}{|c|}{ Heterogeneity: not applicable } \\
\hline \multicolumn{8}{|c|}{ Test for overall effect: $Z=5.29(P<0.0000 I)$} \\
\hline \multicolumn{8}{|c|}{ Test for subgroup differences: $\mathrm{Chi}^{2}=66.2 \mathrm{l}, \mathrm{df}=\mathrm{I}(\mathrm{P}=0.00), \mathrm{I}^{2}=98 \%$} \\
\hline
\end{tabular}




\section{Analysis 13.3. Comparison 13 Clowns/clown doctors versus parental presence, Outcome 3 parental anxiety.}

Review: Non-pharmacological interventions for assisting the induction of anaesthesia in children

Comparison: 13 Clowns/clown doctors versus parental presence

Outcome: 3 parental anxiety

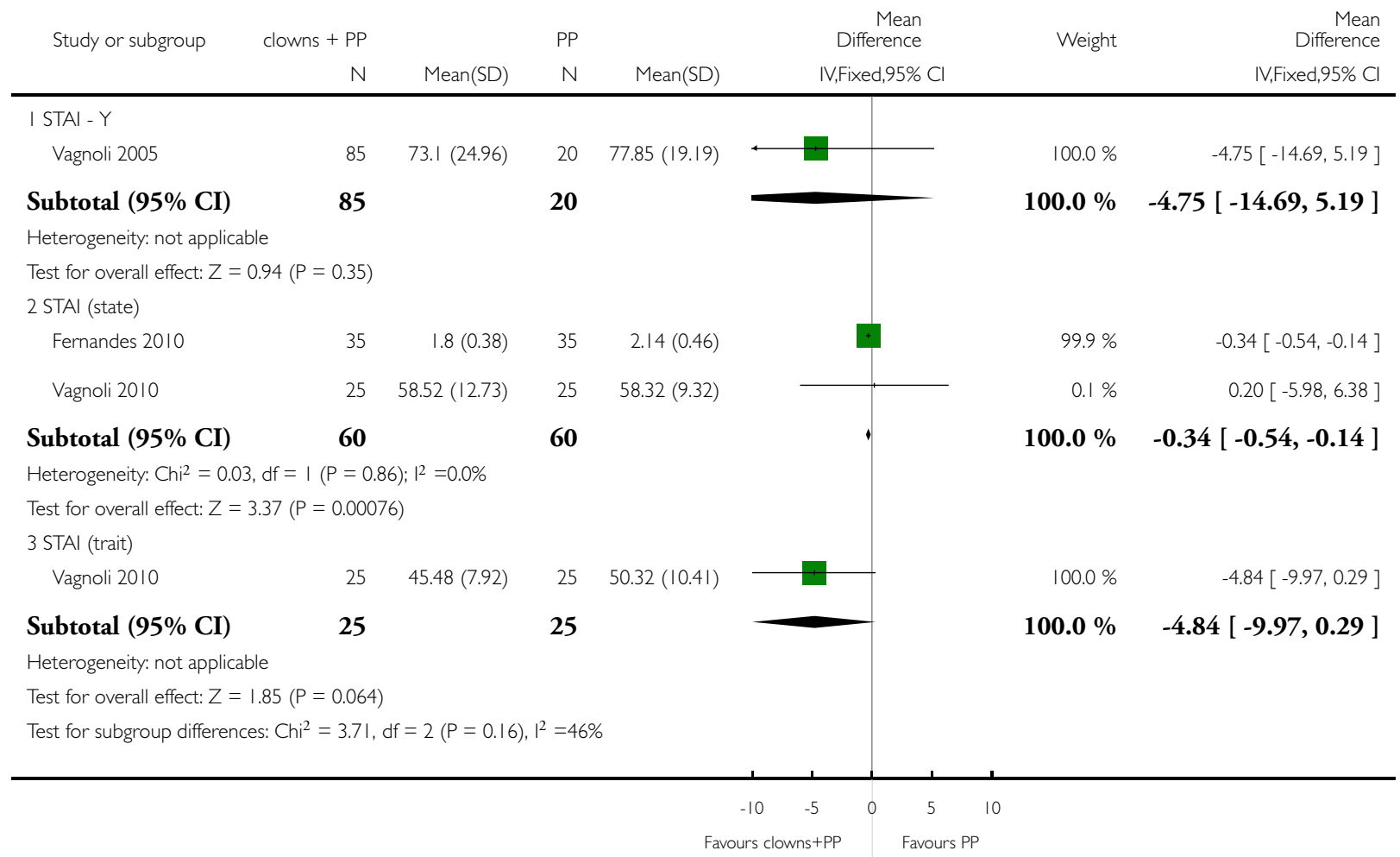


Analysis 13.4. Comparison 13 Clowns/clown doctors versus parental presence, Outcome 4 negative behaviour postop.

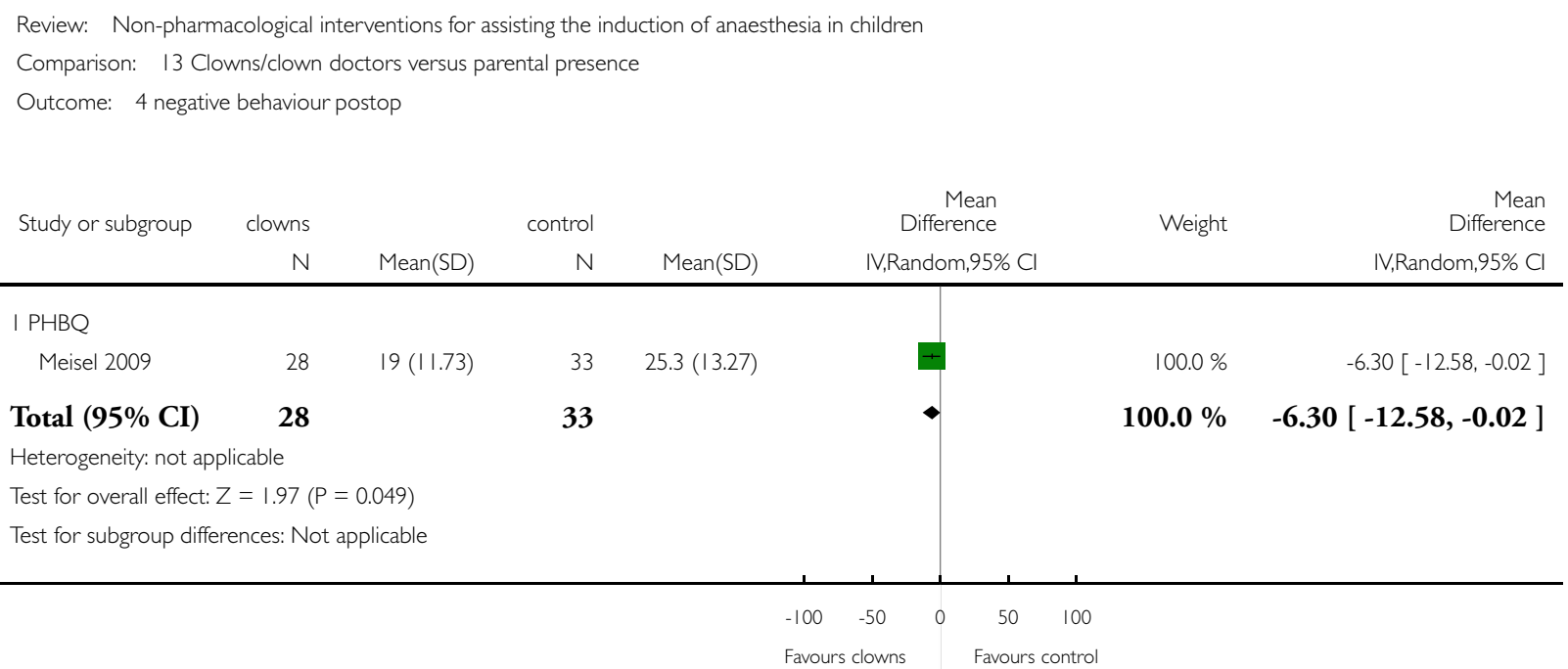

\section{Analysis I4.I. Comparison I4 Clowns/clown doctors versus midazolam, Outcome I anxiety.}

Review: Non-pharmacological interventions for assisting the induction of anaesthesia in children

Comparison: 14 Clowns/clown doctors versus midazolam

Outcome: I anxiety

\begin{tabular}{|c|c|c|c|c|c|c|c|c|}
\hline \multirow[t]{2}{*}{ Study or subgroup } & \multirow{2}{*}{$\begin{array}{r}\text { clowns + PP } \\
N\end{array}$} & \multicolumn{3}{|c|}{ midazolam + PP } & \multicolumn{2}{|c|}{$\begin{array}{r}\text { Mean } \\
\text { Difference }\end{array}$} & \multirow[t]{2}{*}{ Weight } & \multirow{2}{*}{$\begin{array}{r}\text { Mean } \\
\text { Difference } \\
\text { IV,Random,95\% Cl }\end{array}$} \\
\hline & & Mean(SD) & N & Mean(SD) & \multicolumn{2}{|c|}{ IV,Random,95\% Cl } & & \\
\hline \multicolumn{9}{|c|}{ I mYPAS in operating room } \\
\hline Golan 2009 & 21 & $37.3(12.3)$ & 22 & $42(10.6)$ & + & t & $58.1 \%$ & $-4.70[-11.58,2.18]$ \\
\hline Vagnoli 2010 & 25 & $33.16(18.82)$ & 25 & $49.72(22.86)$ & + & & $41.9 \%$ & $-16.56[-28.17,-4.95]$ \\
\hline Subtotal $(95 \% \mathrm{CI})$ & 46 & & 47 & & - & & $100.0 \%$ & $-9.67[-21.14,1.80]$ \\
\hline \multicolumn{9}{|c|}{ Heterogeneity: $\mathrm{Tau}^{2}=46.64 ; \mathrm{Chi}^{2}=2.97, \mathrm{df}=\mathrm{I}(\mathrm{P}=0.08) ; \mathrm{I}^{2}=66 \%$} \\
\hline \multicolumn{9}{|c|}{ Test for overall effect: $Z=1.65(P=0.098)$} \\
\hline \multicolumn{9}{|c|}{$2 \mathrm{mYPAS}$ at application of mask } \\
\hline Golan 2009 & 21 & $62.7(14.6)$ & 22 & $49.9(16)$ & & + & $100.0 \%$ & $12.80[3.65,21.95]$ \\
\hline Subtotal $(95 \% \mathrm{CI})$ & 21 & & 22 & & & $\bullet$ & $100.0 \%$ & $12.80[3.65,21.95]$ \\
\hline \multicolumn{9}{|c|}{ Heterogeneity: not applicable } \\
\hline \multicolumn{9}{|c|}{ Test for overall effect: $Z=2.74(P=0.0061)$} \\
\hline \multicolumn{9}{|c|}{ Test for subgroup differences: $\mathrm{Chi}^{2}=9.0 \mathrm{l}, \mathrm{df}=\mathrm{I}(\mathrm{P}=0.00), \mathrm{I}^{2}=89 \%$} \\
\hline & & & & -100 & -50 & 50 & 100 & \\
\hline \multicolumn{9}{|c|}{ Favours clowns + PP } \\
\hline
\end{tabular}

Non-pharmacological interventions for assisting the induction of anaesthesia in children (Review) 


\section{Analysis 14.2. Comparison I 4 Clowns/clown doctors versus midazolam, Outcome 2 parental anxiety.}

Review: Non-pharmacological interventions for assisting the induction of anaesthesia in children

Comparison: 14 Clowns/clown doctors versus midazolam

Outcome: 2 parental anxiety

\begin{tabular}{|c|c|c|c|c|c|c|c|c|}
\hline \multirow[t]{2}{*}{ Study or subgroup } & clowns + PP & \multicolumn{2}{|r|}{ midazolam + PP } & \multicolumn{3}{|c|}{$\begin{array}{r}\text { Mean } \\
\text { Difference }\end{array}$} & \multirow[t]{2}{*}{ Weight } & \multirow{2}{*}{$\begin{array}{r}\text { Mean } \\
\text { Difference } \\
\text { IV,Fixed,95\% Cl }\end{array}$} \\
\hline & $\mathrm{N}$ & Mean(SD) & N & Mean(SD) & & ed, $95 \% \mathrm{Cl}$ & & \\
\hline \multicolumn{9}{|l|}{ I STAI (state) } \\
\hline Vagnoli 2010 & 25 & $58.52(12.73)$ & 25 & $37.4(13.13)$ & & & $100.0 \%$ & $21.12[13.95,28.29]$ \\
\hline Subtotal $(95 \%$ CI $)$ & 25 & & 25 & & & $\bullet$ & $100.0 \%$ & $21.12[13.95,28.29]$ \\
\hline \multicolumn{9}{|c|}{ Heterogeneity: not applicable } \\
\hline \multicolumn{9}{|c|}{ Test for overall effect: $Z=5.77(P<0.0000 \mathrm{I})$} \\
\hline \multicolumn{9}{|l|}{2 STAl (trait) } \\
\hline Vagnoli 2010 & 25 & $45.48(7.92)$ & 25 & $49.72(22.86)$ & & & $100.0 \%$ & $-4.24[-13.72,5.24]$ \\
\hline Subtotal (95\% CI) & 25 & & 25 & & & & $100.0 \%$ & $-4.24[-13.72,5.24]$ \\
\hline \multicolumn{9}{|c|}{ Heterogeneity: not applicable } \\
\hline \multicolumn{9}{|c|}{ Test for overall effect: $Z=0.88(P=0.38)$} \\
\hline \multicolumn{9}{|c|}{ Test for subgroup differences: $\mathrm{Chi}^{2}=17.48, \mathrm{df}=\mathrm{I}(\mathrm{P}=0.00), \mathrm{I}^{2}=94 \%$} \\
\hline & & & & -100 & -50 & 50 & 100 & \\
\hline \multicolumn{9}{|c|}{ Favours clowns+PP $\quad$ Favours midazolam + PP } \\
\hline
\end{tabular}




\section{Analysis 15.I. Comparison I5 Hypnosis versus midazolam, Outcome I anxiety during induction.}

Review: Non-pharmacological interventions for assisting the induction of anaesthesia in children

Comparison: 15 Hypnosis versus midazolam

Outcome: I anxiety during induction

$\begin{array}{llll}\text { Study or subgroup } & \text { hypnosis } & \text { Risk Ratio } & \text { Wisk Ratio }\end{array}$

I mYPAS $<24$

Calipel 2005

$9 / 23$

$18 / 27$

$100.0 \%$

$0.59[0.33,1.04]$

Subtotal (95\% CI)

Total events: 9 (hypnosis), 18 (midazolam)

Heterogeneity: not applicable

Test for overall effect: $Z=1.82(P=0.069)$

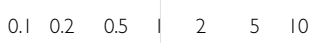

Favours hypnosis Favours midazolam

\section{Analysis I5.2. Comparison I5 Hypnosis versus midazolam, Outcome 2 negative behaviour postop.}

Review: Non-pharmacological interventions for assisting the induction of anaesthesia in children

Comparison: 15 Hypnosis versus midazolam

Outcome: 2 negative behaviour postop

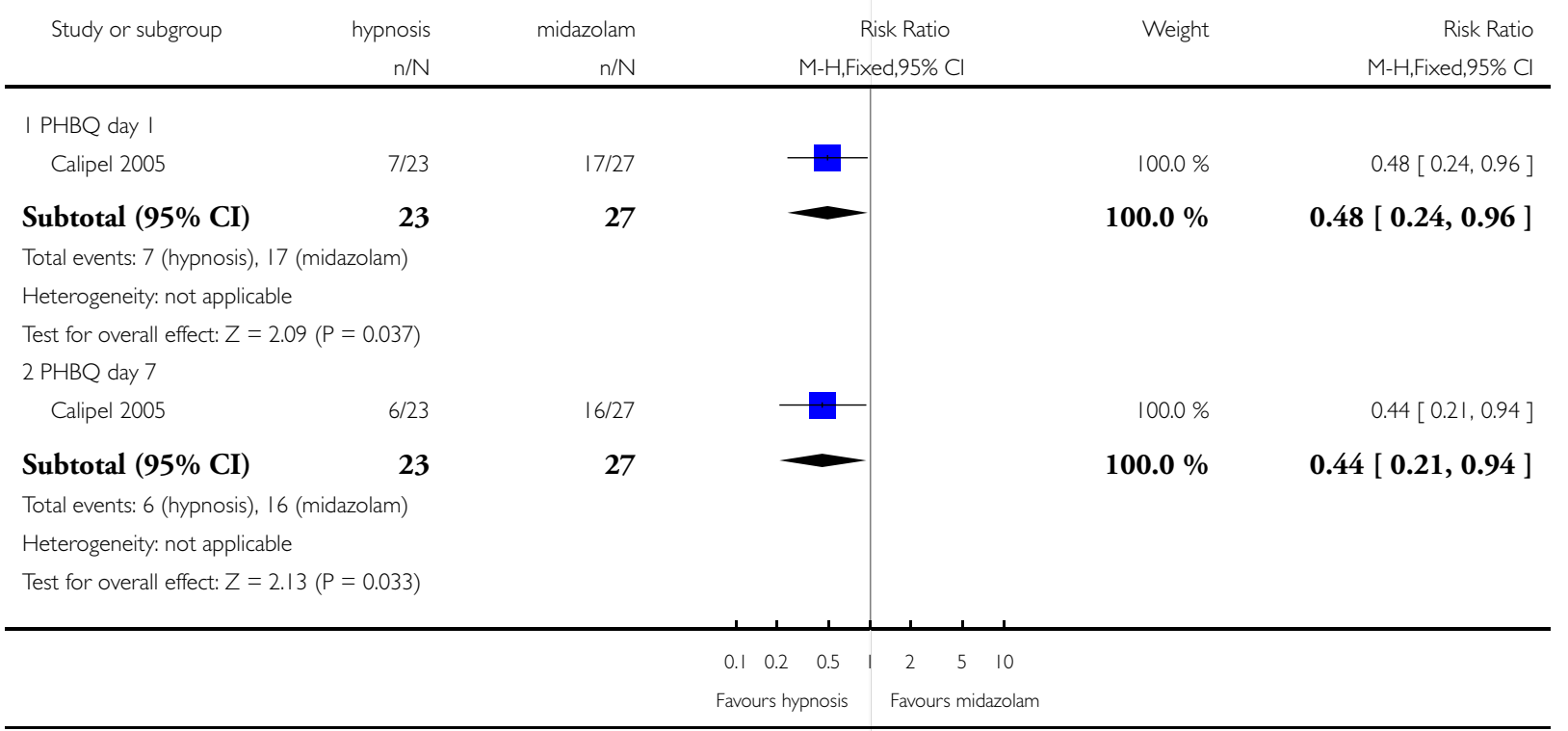

Non-pharmacological interventions for assisting the induction of anaesthesia in children (Review) 


\section{Analysis 16.I. Comparison I6 Acupuncture for parents, Outcome I anxiety during induction.}

Review: Non-pharmacological interventions for assisting the induction of anaesthesia in children

Comparison: 16 Acupuncture for parents

Outcome: I anxiety during induction

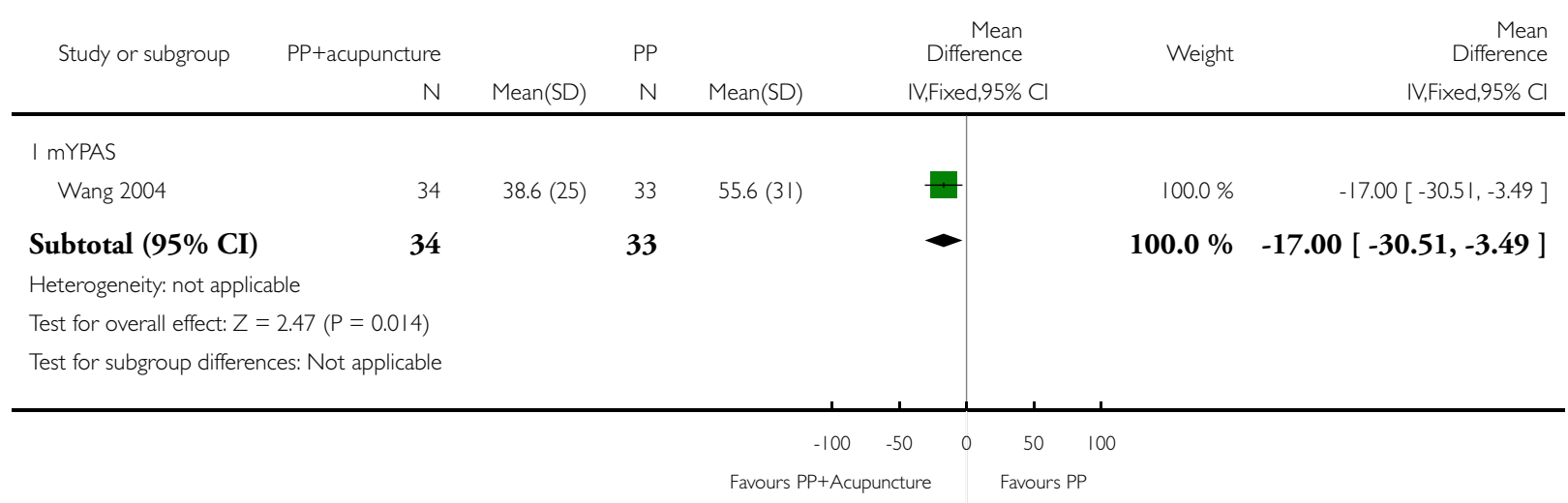




\section{Analysis 16.2. Comparison 16 Acupuncture for parents, Outcome 2 co-operation during induction.}

Review: Non-pharmacological interventions for assisting the induction of anaesthesia in children

Comparison: 16 Acupuncture for parents

Outcome: 2 co-operation during induction

\begin{tabular}{|c|c|c|c|c|c|}
\hline \multirow[t]{2}{*}{ Study or subgroup } & PP+Acup & PP & Risk Ratio & Weight & Risk Ratio \\
\hline & $n / N$ & $\mathrm{n} / \mathrm{N}$ & M-H,Fixed,95\% Cl & & M-H,Fixed,95\% Cl \\
\hline \multicolumn{6}{|l|}{ I perfect induction $\mathrm{ICC}=0$} \\
\hline Wang 2004 & $23 / 34$ & $14 / 33$ & F & $100.0 \%$ & $1.59[1.01,2.53]$ \\
\hline Subtotal (95\% CI) & 34 & 33 & & $100.0 \%$ & $1.59[1.01,2.53]$ \\
\hline \multicolumn{6}{|c|}{ Total events: 23 (PP+Acup), 14 (PP) } \\
\hline \multicolumn{6}{|c|}{ Heterogeneity: not applicable } \\
\hline \multicolumn{6}{|c|}{ Test for overall effect: $Z=1.99(P=0.047)$} \\
\hline
\end{tabular}

$\begin{array}{lllllll}0.1 & 0.2 & 0.5 & 1 & 2 & 5 & 10\end{array}$

Favours PP Favours PP+Acup

\section{Analysis 16.3. Comparison 16 Acupuncture for parents, Outcome 3 parental anxiety.}

Review: Non-pharmacological interventions for assisting the induction of anaesthesia in children

Comparison: 16 Acupuncture for parents

Outcome: 3 parental anxiety

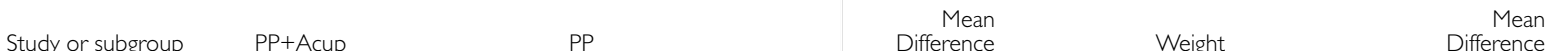

IV,Fixed,95\% Cl

IV,Fixed,95\% C

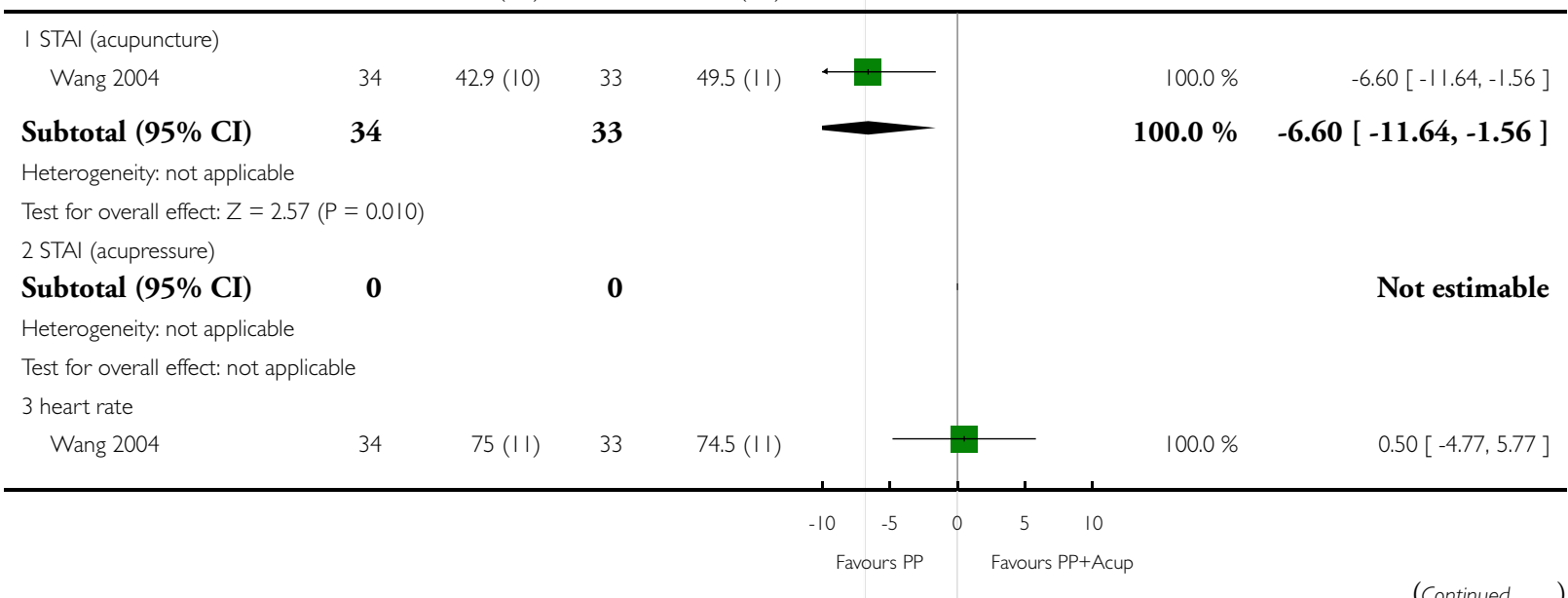




\begin{tabular}{|c|c|c|c|c|c|c|c|}
\hline \multirow[t]{2}{*}{ Study or subgroup } & \multirow{2}{*}{$\begin{array}{r}\mathrm{PP}+\text { Acup } \\
\mathrm{N}\end{array}$} & \multicolumn{3}{|c|}{ PP } & $\begin{array}{r}\text { Mean } \\
\text { Difference }\end{array}$ & \multirow[t]{2}{*}{ Weight } & \multirow{2}{*}{$\begin{array}{r}\text { (... Continued) } \\
\text { Mean } \\
\text { Difference } \\
\text { IV,Fixed,95\% Cl }\end{array}$} \\
\hline & & Mean(SD) & $\mathrm{N}$ & Mean(SD) & IV,Fixed,95\% Cl & & \\
\hline Subtotal (95\% CI) & 34 & & 33 & & & $100.0 \%$ & $0.50[-4.77,5.77]$ \\
\hline \multicolumn{8}{|c|}{ Heterogeneity: not applicable } \\
\hline \multicolumn{8}{|c|}{ Test for overall effect: $Z=0.19(P=0.85)$} \\
\hline \multicolumn{8}{|c|}{4 systolic blood pressure $(\mathrm{mmHg})$} \\
\hline Wang 2004 & 34 & $119(14.8)$ & 33 & $119(14.6)$ & & $100.0 \%$ & $0.0[-7.04,7.04]$ \\
\hline Subtotal $(95 \% \mathrm{CI})$ & 34 & & 33 & & & $100.0 \%$ & $0.0[-7.04,7.04]$ \\
\hline \multicolumn{8}{|c|}{ Heterogeneity: not applicable } \\
\hline \multicolumn{8}{|c|}{ Test for overall effect: $Z=0.0(P=1.0)$} \\
\hline \multicolumn{8}{|c|}{5 diastolic blood pressure $(\mathrm{mmHg})$} \\
\hline Wang 2004 & 34 & $76.9(11)$ & 33 & $76.9(9)$ & & $100.0 \%$ & $0.0[-4.81,4.81]$ \\
\hline Subtotal $(95 \% \mathrm{CI})$ & 34 & & 33 & & & $100.0 \%$ & $0.0[-4.81,4.81]$ \\
\hline \multicolumn{8}{|c|}{ Heterogeneity: not applicable } \\
\hline \multicolumn{8}{|c|}{ Test for overall effect: $Z=0.0(P=1.0)$} \\
\hline \multicolumn{8}{|c|}{ Test for subgroup differences: $\mathrm{Ch}^{2}=5.01, \mathrm{df}=3(\mathrm{P}=0.17), \mathrm{I}^{2}=40 \%$} \\
\hline & & & & & 5 & & \\
\hline
\end{tabular}




\section{Analysis I7.I. Comparison 17 Videos for parents, Outcome I parental anxiety.}

Review: Non-pharmacological interventions for assisting the induction of anaesthesia in children

Comparison: 17 Videos for parents

Outcome: I parental anxiety

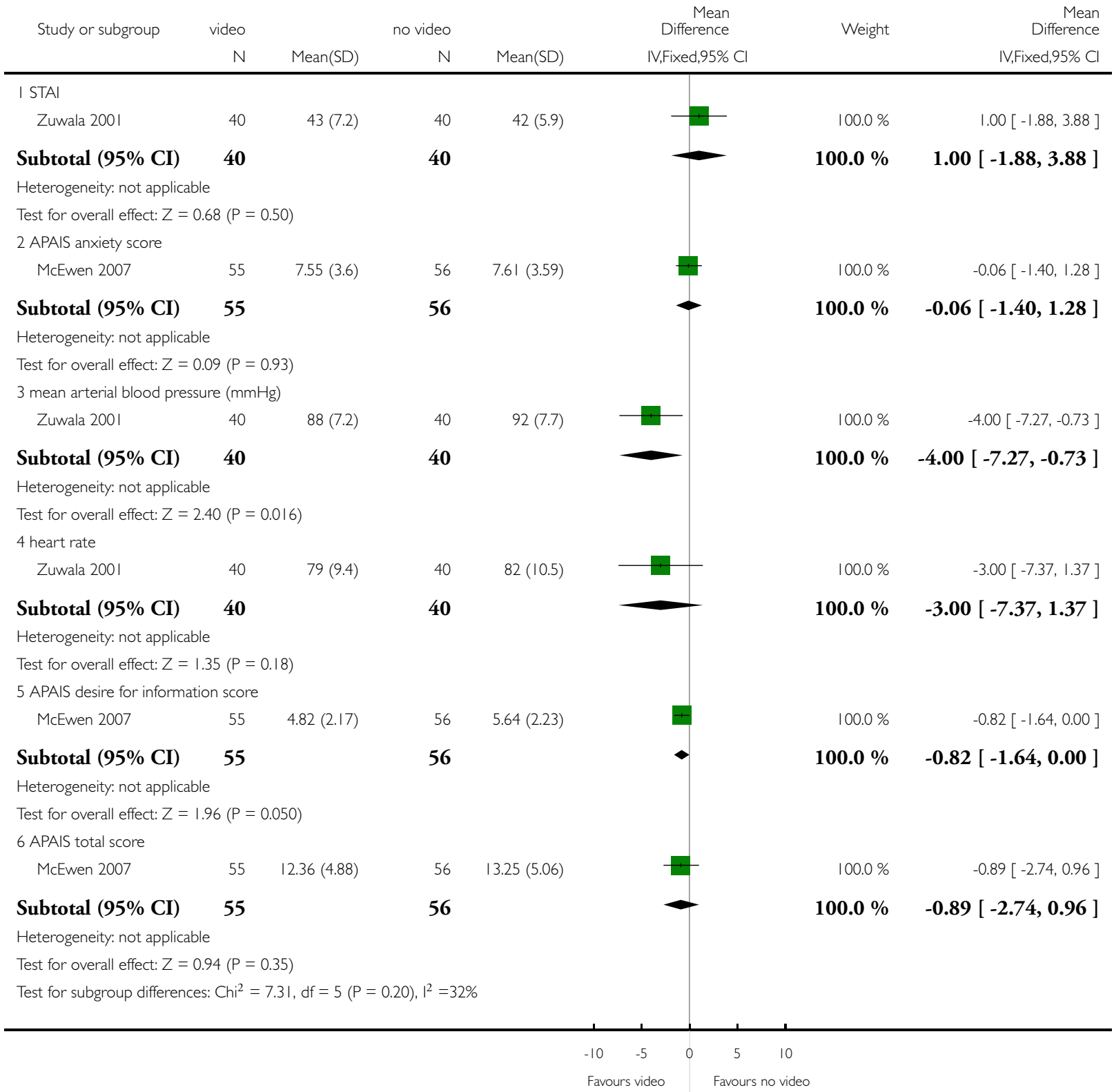

Non-pharmacological interventions for assisting the induction of anaesthesia in children (Review)

Copyright @ 2015 The Cochrane Collaboration. Published by John Wiley \& Sons, Ltd. 


\section{A P P E N D I C E S}

\section{Appendix I. Search strategy for CENTRAL, the Cochrane Library}

\#1 MeSH descriptor Anesthesia explode all trees

$\# 2$ an? esthe* or induc*

\#3 (\#1 OR \#2)

\#4 MeSH descriptor Anxiety explode all trees

\#5 MeSH descriptor Stress, Psychological explode all trees

\#6 distress or distract* or cooperat*

\#7 (\#4 OR \#5 OR \#6)

\#8 MeSH descriptor Child explode all trees

\#9 $\mathrm{MeSH}$ descriptor Adolescent explode all trees

\#10 child

\#11 (\#8 OR \#9 OR \#10)

\#12 MeSH descriptor Preoperative Care explode all trees

\#13 preoperat*

\#14 (\#12 OR \#13)

\#15 (\#3 AND \#7 AND \#11 AND \#14)

\section{Appendix 2. Search strategy for MEDLINE (Ovid SP)}

1. exp Anesthesia/ or an?esthe*.ti,ab. or induc*.ti,ab.

2. exp Anxiety/ or exp Stress, Psychological/ or (distress or distract* or cooperat*).ti,ab.

3. exp Child/ or exp Adolescent/ or child.mp.

4. 1 and 2 and 3

5. ((randomized controlled trial or controlled clinical trial).pt. or randomized.ab. or placebo.ab. or clinical trials as topic.sh. or randomly.ab. or trial.ti.) not (animals not (humans and animals)).sh.

6. 4 and 5

\section{Appendix 3. Search strategy for EMBASE (Ovid SP)}

1. exp anesthesia/ or an?esthe*.ti,ab. or induc*.ti,ab.

2. exp anxiety/ or exp mental stress/ or (distress or distract* or cooperat*).ti,ab.

3. exp child/ or exp adolescent/ or child.mp.

4. 1 and 2 and 3

5. (placebo.sh. or controlled study.ab. or random*.ti,ab. or trial*.ti,ab. or ((singl* or doubl* or trebl* or tripl*) adj3 (blind* or mask*)).ti,ab.) not (animals not (humans and animals)).sh.

6. 4 and 5

\section{Appendix 4. Search strategy for PsycINFO (Ovid SP)}

1. exp Anesthetic Drugs/ or exp "Anesthesia (Feeling)"/ or (an?esthe* or induc*).ti,ab.

2. exp Anxiety/ or exp Psychological Stress/ or (distress or distract* or cooperat*).ti,ab.

3. (child* or adolesc*).af.

4. preoperat*.af.

5. 1 and 2 and 3 and 4 


\section{Appendix 5. Search strategy for CINAHL (EBSCOhost)}

S1 ((MH “Anesthesia+”) OR (MH “Anesthesia Induction”)) OR (an?esthe* or induc*)

S2 ((MM “Anxiety”) OR (MM“Stress, Psychological”)) OR (distress or distract* or cooperat*)

S3 ((MM “Child+”) OR (MM “Adolescence+”)) OR child*

S4 (MM "Preoperative Care+") OR preoperativ*

S5 S1 and S2 and S3 and S4

\section{Appendix 6. Search strategy for ISI Web of Science}

\#1 TS=(an?esthe* or induc*)

\#2 TS=(anxiety or (stress SAME (mental or psychological)) or distress or distract* or cooperat $\left.{ }^{*}\right)$

\#3 TS=(child* or adolescent*)

\#4 TS=(random* or (trial* same (controlled* or clinical)) or multicenter* or prospective or

placebo $\left.^{*}\right)$ or $\mathrm{TS}=\left(\left(\right.\right.$ blind $^{*}$ or mask $\left.{ }^{*}\right)$ same (single or double or triple or treble) $)$

\#5 \#4 AND \#3 AND \#2 AND \#1

\section{WHAT'S NEW}

Last assessed as up-to-date: 28 August 2014.

\begin{tabular}{l|l} 
Date Event & Description
\end{tabular}

7 July 2015 New search has been performed

We added 11 new trials (Akinci 2008; Berghmans 2012; Fernandes 2010; Golan 2009; Kain 2009; Kazak 2010; MacLaren 2008; Meisel 2009; Mifflin 2012; Vagnoli 2010; Wright 2010).

7 July 2015 New citation required but conclusions have not changed
The main objective of this review was to update the previous Cochrane systematic review known as 'Non-pharmacological interventions for assisting the induction of anaesthesia in children' (Yip 2009) that concluded that some interventions (parental acupuncture, clown doctors, hypnosis, low sensory stimulation and hand-held video games) were likely to be helpful in reducing children's anxiety and improving their co-operation during induction of general anaesthesia. The original review included 17 randomized controlled trials (RCTs)

In updating the review, two new authors (CC and MA) joined the original team (PY, PM, AVC and AMC). AVC is no longer an author or involved in this review. We found 25 new trials and included 11 of them since they met our inclusion criteria (RCT of a non-pharmacological intervention implemented on the day of surgery or anaesthesia) . Fourteen RCTs were excluded either because inappropriate induction methods $(\mathrm{n}=5)$ or interventions $(\mathrm{n}=8)$ were used. We also excluded one which was not randomized and three studies involving adults

In general our review reached the same conclusions as Yip 
2009. However, we included more trials and thus now have more precise estimates on some risk ratios. Furthermore, we applied several additional sensitivity and subgroup analyses which supported the overall results

We have also extended our search strategy to include additional electronic databases

In the previous version, the databases were searched until December 2008. We reran the searches until 28 August 2014. We have included a study flow diagram which documents the selection process of the trials included in the update review (Figure 1), a risk of bias graph with authors' decision of each included study (Figure 2) and risk of bias summary of each included study (Figure 3). We added one study to 'Studies awaiting classification'. 
Figure I. Study flow diagram of literature search results for this review UPDATE only (results not available for earlier version of the review Yip 2009). We reran the search in August 2014. *We will deal with the single study of interest found when we update the review.

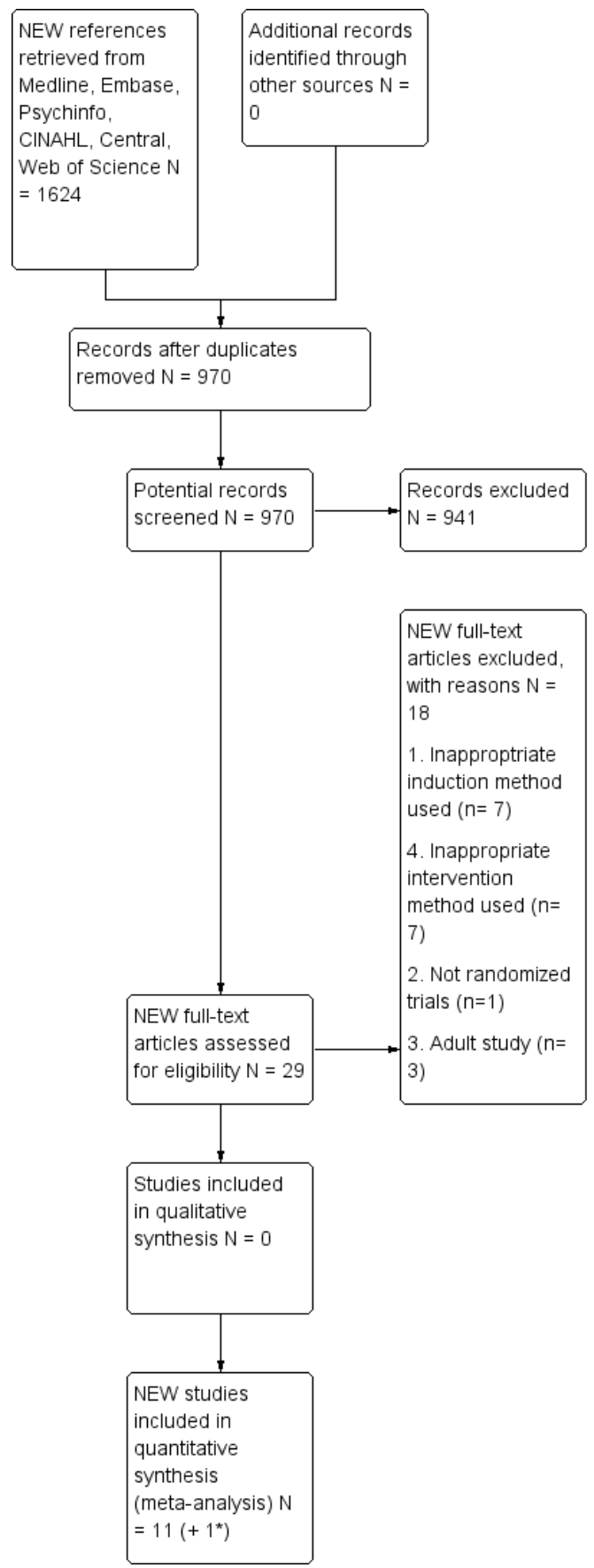


Figure 2. Risk of bias graph, authors' decision of each included study(review plus update).

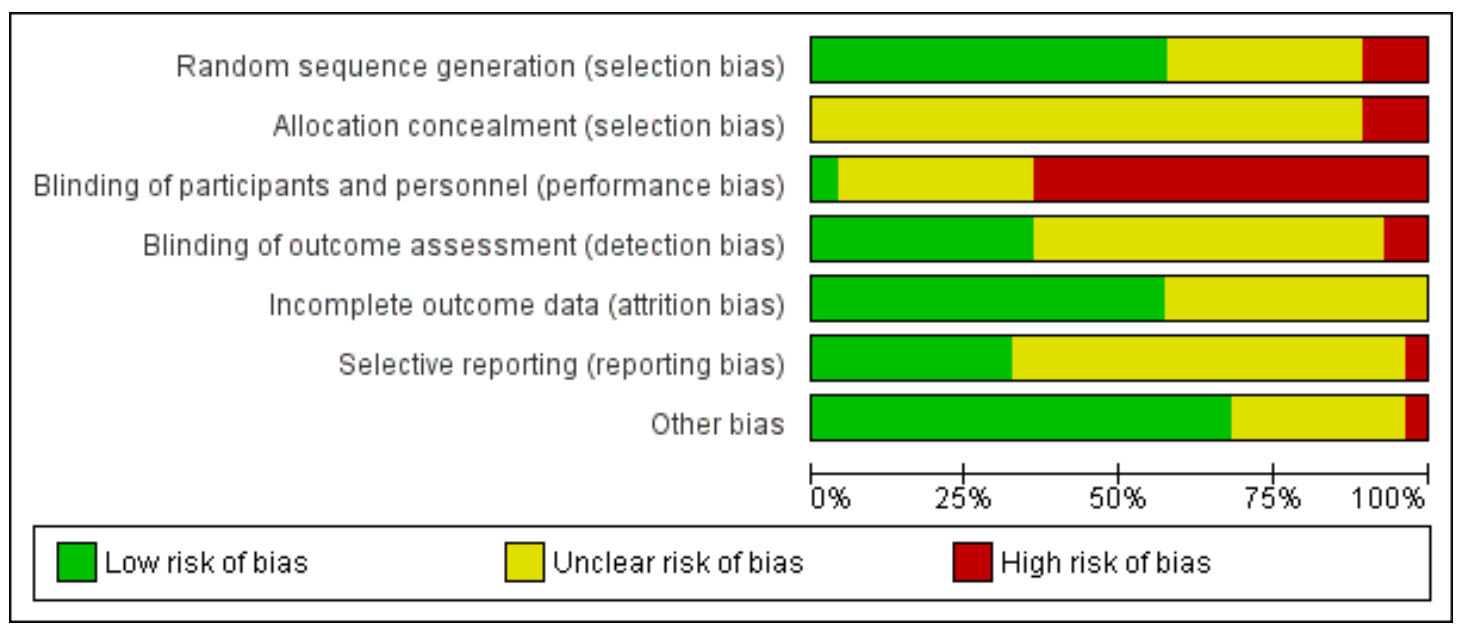


Figure 3. Risk of bias summary for each included study in both the review and update.

\begin{tabular}{|c|c|c|c|c|c|c|c|}
\hline & 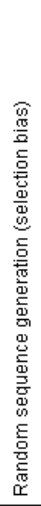 & 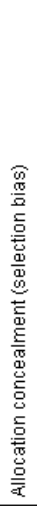 & 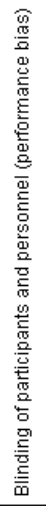 & 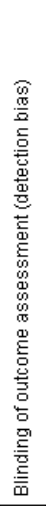 & 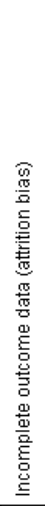 & 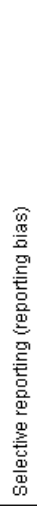 & 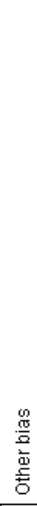 \\
\hline Akinci 2008 & + & $?$ & 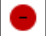 & ? & + & $?$ & + \\
\hline Arai 2007 & + & $?$ & - & + & $?$ & ? & $?$ \\
\hline Berghmans 2012 & $\odot$ & $?$ & $?$ & $\odot$ & $\odot$ & $?$ & + \\
\hline Bevan 1990 & $\odot$ & $\odot$ & $?$ & $?$ & $?$ & + & $?$ \\
\hline Calipel 2005 & $?$ & $?$ & $?$ & ? & + & $?$ & + \\
\hline Campbell 2005 & + & $?$ & 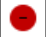 & 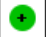 & $?$ & ? & + \\
\hline Fernandes 2010 & $\odot$ & $\odot$ & $\odot$ & $\odot$ & 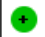 & + & 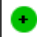 \\
\hline Golan 2009 & $\odot$ & $?$ & - & + & + & $?$ & + \\
\hline Kain 1996b & $\odot$ & $?$ & $?$ & 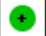 & $?$ & + & $\bullet$ \\
\hline Kain 1998 & $?$ & $?$ & 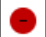 & $?$ & $?$ & + & $?$ \\
\hline Kain 2000 & + & $?$ & - & ? & $?$ & + & + \\
\hline Kain 2001 & $\odot$ & $?$ & $\odot$ & $?$ & 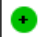 & $?$ & $?$ \\
\hline Kain 2003 & 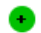 & $?$ & 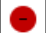 & ? & + & ? & + \\
\hline Kain 2004 & $?$ & ? & $\theta$ & + & + & ? & + \\
\hline Kain 2007 & 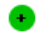 & $?$ & $?$ & ? & $?$ & $?$ & $?$ \\
\hline Kain 2009 & + & $?$ & - & + & $?$ & + & + \\
\hline Kazak 2010 & $?$ & $?$ & $?$ & ? & 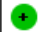 & $?$ & $\odot$ \\
\hline MacLaren 2008 & $?$ & ? & $?$ & $?$ & $?$ & + & $\theta$ \\
\hline McEwen 2007 & $\odot$ & $?$ & $\theta$ & ? & $?$ & ? & + \\
\hline Meisel 2009 & $\Theta$ & $\odot$ & - & ? & + & + & $?$ \\
\hline Mifflin 2012 & 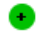 & $?$ & $\odot$ & ? & 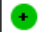 & $?$ & 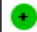 \\
\hline Palermo 2000 & $?$ & $?$ & - & ? & $?$ & $\odot$ & + \\
\hline Patel 2006 & $?$ & $?$ & - & ? & + & $?$ & + \\
\hline Vagnoli 2005 & $?$ & $?$ & $\theta$ & $\theta$ & + & $?$ & $?$ \\
\hline Vagnoli 2010 & + & $?$ & $?$ & + & + & $?$ & + \\
\hline Wang 2004 & $\odot$ & $?$ & + & $\odot$ & $?$ & + & + \\
\hline Wright 2010 & + & $?$ & - & $\odot$ & 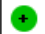 & $?$ & $\bullet$ \\
\hline Zuwala 2001 & $?$ & $?$ & $?$ & $?$ & + & $?$ & $?$ \\
\hline
\end{tabular}




\section{H I S T O R Y}

Protocol first published: Issue 2, 2007

Review first published: Issue 3, 2009

\begin{tabular}{l|ll}
\hline Date & Event & Description \\
\hline 6 December 2007 & Amended & Converted to new review format. \\
\hline
\end{tabular}

\section{CONTRIBUTIONSOFAUTHORS}

Conceiving the review: Allan M Cyna (AMC)

Co-ordinating the review: AMC, Philippa Middleton (PM)

Undertaking manual searches: PM, Peggy Yip (PY),

Screening search results: AMC, PM, PY, Anne Manyande (AM)

Organizing retrieval of papers: PM, PY,

Screening retrieved papers against inclusion criteria: AMC, PM, PY, AM

Appraising quality of papers: AMC, PM, PY, Cheryl S Chooi (CSC), AM

Abstracting data from papers: AMC, PM, AM, CSC

Writing to authors of papers for additional information: PM

Data management for the review: PM, PY, AM

Entering data into Review Manager 5 (RevMan 5.3): PM, PY, AM

RevMan statistical data: PM, PY, AM

Checking entry of data: (data entered by person one: PM; data checked by AMC, AM or PY)

Interpretation of data: AMC, PM, PY

Statistical inferences: AMC, PM, PY

Writing the review: PY, AMC, PM, (Elizabeth Holt wrote a first draft protocol)

Performing previous work that was the foundation of the present study: AMC

Guarantor for the review (one author) AMC

Person responsible for reading and checking review before submission: AMC 


\section{DECLARATIONSOF INTEREST}

Anne Manyande: none known

Allan M Cyna: Payment for lectures including service on speakers bureaus: South Australian Society of Hypnosis (Course teaching). Travel and accomodation and meeting expenses unrelated to this research: AAGBI London Jan 2011; MSA Kuala Lumpar 2011; Wellington NZ Haemophilia nurses meeting 2012; Birth International 2013

Peggy Yip: none known

Cheryl S Chooi: none known

Philippa Middleton: none known

\section{SOURCES OF SUPPORT}

\section{Internal sources}

- ARCH, Robinson Insitute, The University of Adelaide, Australia.

\section{External sources}

- No sources of support supplied

\section{DIFFERENCES BETWEEN PROTOCOLANDREVIEW}

None noted

\section{NOT E S}

Child outcomes e.g. anxiety are not prefaced with 'child' as these are the main outcomes of the review. However outcomes pertaining to parents are designated 'Parental'

\section{NDEX TERMS \\ Medical Subject Headings (MeSH)}

*Cooperative Behavior; Acupuncture Therapy; Anesthesia, General [* psychology]; Anxiety [* prevention \& control]; Hypnosis, Anesthetic [psychology]; Music Therapy; Noise [prevention \& control]; Parents [psychology]; Physician’s Role [psychology]; Stress, Psychological [*prevention \& control]; Video Games [psychology] 


\section{MeSH check words}

Child; Humans 